\title{
Divergent Synthesis of Heparan Sulfate Oligosaccharides
}

\author{
Steven B. Dulaney, ${ }^{\dagger}$ Yongmei Xu, ${ }^{\ddagger}$ Peng Wang, ${ }^{\dagger}$ Gopinath Tiruchinapally, ${ }^{\dagger}$ Zhen Wang, $^{\dagger}$ Jolian Kathawa, $^{\dagger}$ \\ Mohammad H. El-Dakdouki, ${ }^{\dagger, \S}$ Bo Yang, ${ }^{\dagger}$ Jian Liu, ${ }^{*},{ }^{\ddagger}$ and Xuefei Huang ${ }^{*}, \dagger$ \\ ${ }^{\dagger}$ Department of Chemistry, Michigan State University, 578 S. Shaw Lane, East Lansing, Michigan 48824, United States \\ ${ }^{\ddagger}$ Division of Medicinal Chemistry and Natural Products, UNC Eshelman School of Pharmacy, University of North Carolina, \\ Chapel Hill, North Carolina 27599, United States \\ ${ }^{\S}$ Department of Chemistry, Beirut Arab University, P.O. Box 11-5020, Riad El Solh 11072809, Beirut, Lebanon
}

\section{Supporting Information}

ABSTRACT: Heparan sulfates are implicated in a wide range of biological processes. A major challenge in deciphering their structure and activity relationship is the synthetic difficulties to access diverse heparan sulfate oligosaccharides with welldefined sulfation patterns. In order to expedite the synthesis, a divergent synthetic strategy was developed. By integrating chemical synthesis and two types of $O$-sulfo transferases, seven different hexasaccharides were obtained from a single hexasaccharide precursor. This approach combined the flexibility of chemical synthesis with the selectivity of enzyme-catalyzed sulfations, thus simplifying the overall synthetic operations. In an attempt to establish structure activity relationships of heparan sulfate binding with its receptor, the synthesized oligosaccharides were incorporated onto a glycan microarray, and their bindings with a growth factor FGF-2 were examined. The unique combination of chemical and enzymatic approaches expanded the capability of oligosaccharide synthesis. In addition, the well-defined heparan sulfate structures helped shine light on the fine substrate specificities of biosynthetic enzymes and confirm the potential sequence of enzymatic reactions in biosynthesis.

\section{INTRODUCTION}

Heparan sulfate (HS) is a class of highly charged polysaccharides, which play important roles in a variety of biological events such as cell proliferation, viral infection, and cancer development. ${ }^{1-4} \mathrm{HS}$ is made of disaccharide units of glucosamine $\alpha$-1,4-linked with a uronic acid. ${ }^{5}$ In nature, the backbone of HS can be extensively sulfated by a variety of enzymes. ${ }^{6}$ For example, the glucosamine residue can bear sulfates on its amine, $3-\mathrm{OH}$ or $6-\mathrm{OH}$, while the uronic acid including both glucuronic acid and iduronic acid can be 2-O sulfated. As the enzymatic reactions are often not complete, natural sources of HS are highly heterogeneous. ${ }^{7}$ The structural diversity bestows HS the abilities to interact with a wide range of biological targets. ${ }^{4}$ To better understand its structure activity relationship, synthesis of well-defined HS structures becomes crucial to avoid structural heterogeneities of naturally existing HS.

Tremendous advances have been made in HS oligosaccharide synthesis during the past two decades. ${ }^{5,8-11}$ Chemical synthesis of HS relies on stepwise construction of the backbone and strategic protection of the hydroxyl groups that will be ultimately sulfated. Although complex HS structures have been constructed, ${ }^{12-39}$ chemical synthesis is still highly challenging and unexpected obstacles in stereoselectivity and reactivity can rise. ${ }^{40,41}$ Thus, continual efforts are needed to expedite the synthesis and enable the creation of diverse HS structures. $17,28,31,34,42,43$
Recently, enzymatic synthesis of HS has emerged as a synthetic tool, ${ }^{23,27,44,45}$ which proved highly efficient for certain targets without the need for selective protection/deprotection. However, one limitation is that some HS sequences are not accessible through the enzymatic approach due to substrate specificities of the enzymes.

Herein, we report the development of a synthetic approach by combining the flexibility of chemical synthesis and the regioselectivities of HS biosynthetic enzymes. The iduronic acid containing HS backbones were chemically prepared, and a selective chemical sulfation strategy was developed to create multiple HS sequences. To further diversify HS structures, enzymatic sulfations were carried out using 2-O-sulfotransferase (2-OST) and 6-O-sulfotransferase (6-OST). The synthetic HS oligosaccharides were subsequently immobilized on a carbohydrate microarray to analyze the structural requirements for HS binding with fibroblast growth factor-2 (FGF-2).

\section{RESULTS AND DISCUSSION}

Chemical Synthesis of HS Backbones. Our synthesis commenced from the construction of HS backbones with disaccharide donor $\mathbf{1}$ as a key building block. $\mathbf{1}$ can serve as the

Received: September 15, 2015

Published: November 17, 2015 
Scheme 1
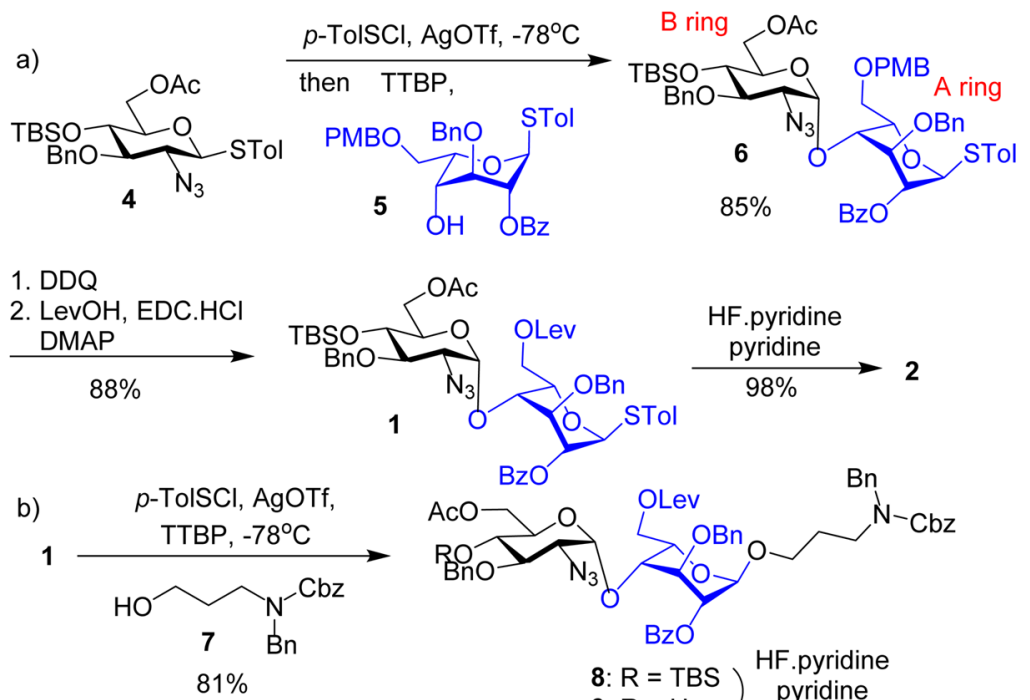

$\mathrm{OBz}$

$85 \%$

$\mathrm{BzO}$
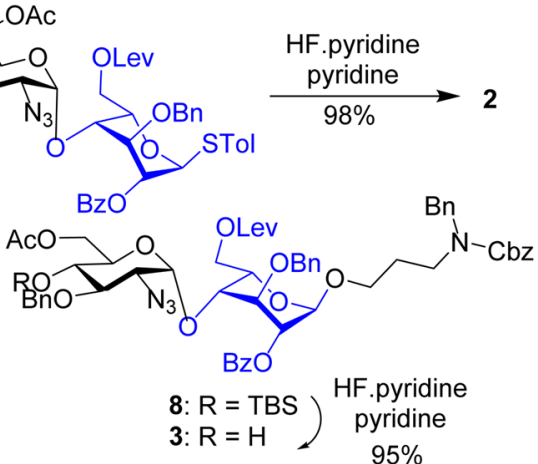

nonreducing end of HS. At the same time, it can be readily transformed to the bifunctional module 2 for backbone elongation, as well as disaccharide 3 with a functional linker at the reducing terminal of $\mathrm{HS}$.
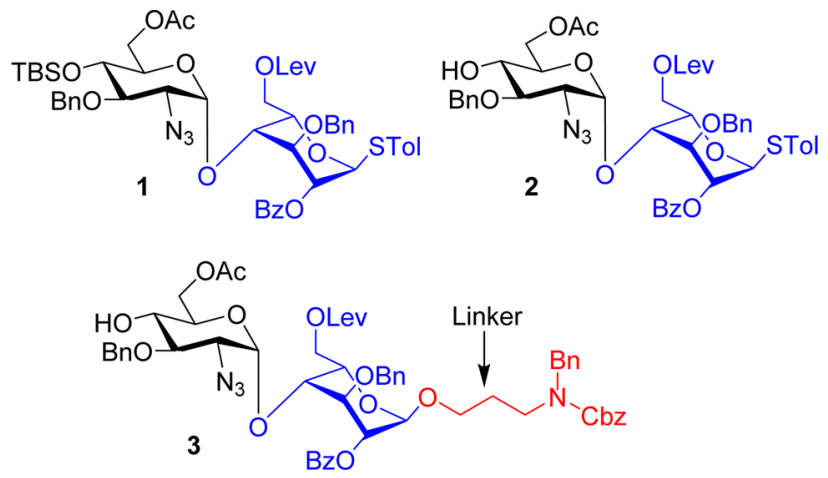

The preparation of disaccharide $\mathbf{1}$ began from the reaction of glucosamine derivative $4^{17}$ and idoside $5^{17}$ (Scheme 1a). Preactivation $^{46}$ of donor 4 with $p$-TolSCl and AgOTf at $-78{ }^{\circ} \mathrm{C}$, followed by the addition of acceptor 5 and 2,4,5-tritert-butylpyrimidine (TTBP $)^{47}$ as the base, led to the $\alpha$-linked disaccharide 6 in $85 \%$ yield as the sole anomer isolated. The stereochemistry of the newly formed glycosyl linkage was confirmed by NMR analysis with ${ }^{3} J_{\mathrm{H} 1 \mathrm{~B}-\mathrm{H} 2 \mathrm{~B}}=3.7 \mathrm{~Hz}$ and ${ }^{1} J_{\mathrm{C} 1 \mathrm{~B}-\mathrm{H} 1 \mathrm{~B}}=171 \mathrm{~Hz}^{48}$ As the 6-O-p-methoxylbenzyl (PMB) moiety on a glycosyl donor tends to participate during glycosylation, forming 1,6-anhydro glycan, ${ }^{49}$ the 6-O-PMB group on disaccharide 6 was replaced with levuniloyl (Lev), producing the key building block 1 . Direct glycosylation of 6-OLev-containing idoside acceptor by donor 4 failed to give disaccharide 1 in high yield, presumably because Lev was more electron-withdrawing than $\mathrm{PMB}$, leading to lower nucleophilicity of the 6-O-Lev-containing acceptor. Removal of the tertbutyldimethylsilyl (TBS) moiety from 1 generated disaccharide acceptor $\mathbf{2}$ in $98 \%$ yield (Scheme 1a). Glycosylation of alcohol $7^{17}$ by 1 with subsequent TBS removal produced disaccharide 3 in $77 \%$ overall yield (Scheme $1 \mathrm{~b}$ ).

With disaccharide building blocks 1-3 in hand, glycosylation was performed to elongate the chain length (Scheme 2). Glycosylation of acceptor $\mathbf{2}$ by disaccharide donor $\mathbf{1}$ produced tetrasaccharide 9 in $81 \%$ yield. The $4+2$ glycosylation between 9 and disaccharide 3 generated the fully protected HS hexasaccharide backbone 10 (61\% yield) (Scheme $2 \mathrm{a}$ ). Analogously, tetrasaccharide 11 was prepared from the reaction of 1 with 3 (Scheme $2 b$ ). In order to improve the synthetic efficiency, onepot synthesis of hexasaccharide 10 was tested (Scheme 2c). Upon preactivation of $\mathbf{1}$ by $p$-TolSCl/AgOTf at $-78{ }^{\circ} \mathrm{C}$, acceptor 2 was added. The reaction temperature was warmed up to $-30{ }^{\circ} \mathrm{C}$ over $2 \mathrm{~h}$ when TLC analysis showed complete consumption of acceptor $\mathbf{2}$. Subsequently, acceptor $\mathbf{3}$ was added to the reaction, followed by $p$-TolSCl/AgOTf, which led to the formation of hexasaccharide 10 in $67 \%$ yield without the need to purify the tetrasaccharide intermediate 9 .

Challenges in Deprotection and Chemical Sulfation of HS Hexasaccharide. To produce HS oligosaccharides, 10 was subjected to deprotection and chemical sulfation. Since idose was utilized as an iduronic acid surrogate in backbone formation, the first step in the deprotection was to convert the idosyl units to iduronic acids. The 6-O Lev esters in 10 were removed selectively with hydrazine, followed by bis(acetoxy)iodobenzene (BAIB) assisted 2,2,6,6-tetramethyl-1-piperidinyloxyl (TEMPO) oxidation (Scheme 3). ${ }^{50}$ The newly formed carboxylic acids were protected as benzyl esters with phenyl diazomethane, ${ }^{51}$ forming $\mathbf{1 2}$ for the ease of purification and characterization.

In order to install sulfates, the temporary acyl protective groups needed to be removed. This was accomplished by treating 12 with lithium hydroxide and hydrogen peroxide, followed by sodium hydroxide (Scheme 3). Staudinger reduction of the azides provided hexasaccharide bearing free alcohols and amines. However, sulfation of this newly formed hexasaccharide failed to generate the desired hexasaccharide with several undersulfated and unidentified side products found in the reaction mixture. Addition of excess sulfation agents (up to $1 \mathrm{M}$ ), exploration of different sulfation conditions including $\mathrm{SO}_{3} \cdot \mathrm{NEt}_{3}$ in $\mathrm{DMF}$, prolonging the reaction time, and raising the reaction temperatures did not lead to the anticipated fully $\mathrm{N}$ - and $\mathrm{O}$-sulfated hexasaccharide.

In order to overcome the difficulty in sulfation, we explored the alternative of sulfating carboxylic ester containing substrate. $^{29,36}$ Methyl ester $\mathbf{1 4}$ was prepared, and its acyl protective groups were removed under trans-esterification conditions 
Scheme 2. Synthesis of Heparan Sulfate Backbones 10 and 11
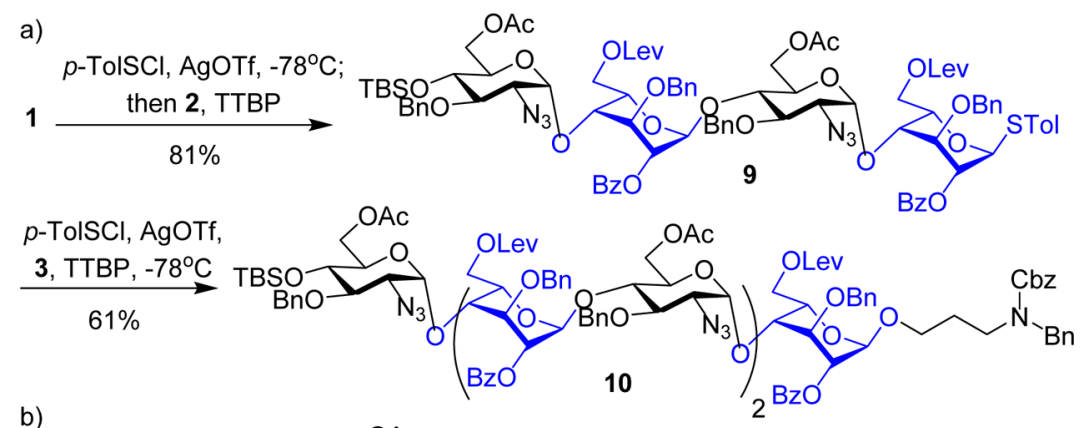

b)

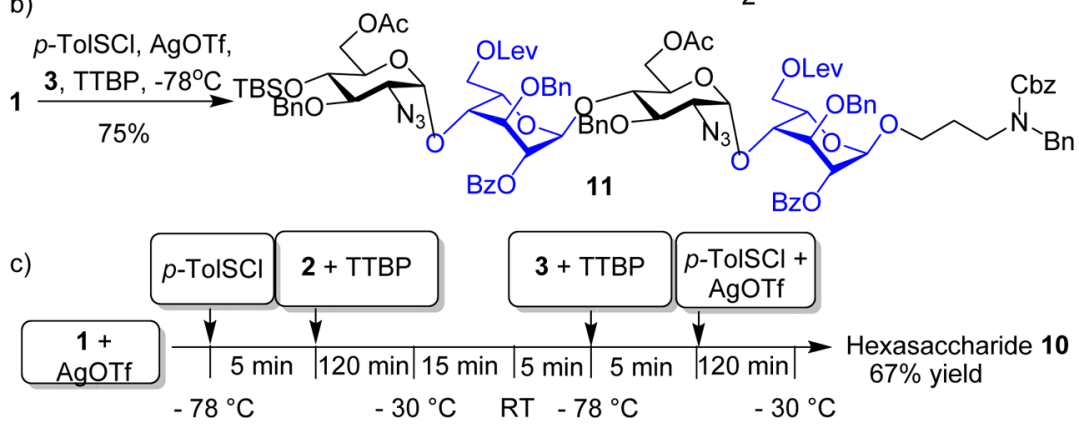

\section{Scheme 3}

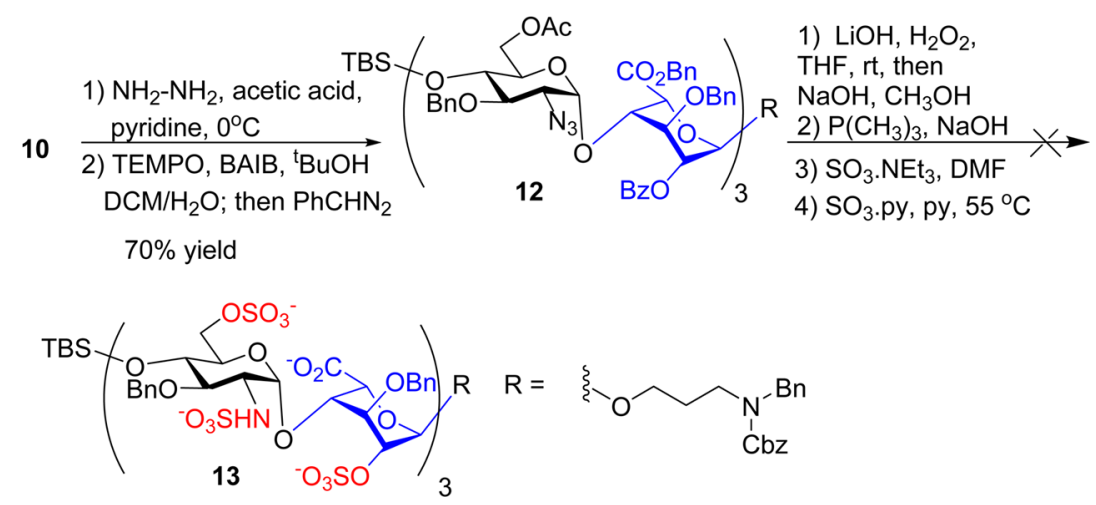

\section{Scheme 4}

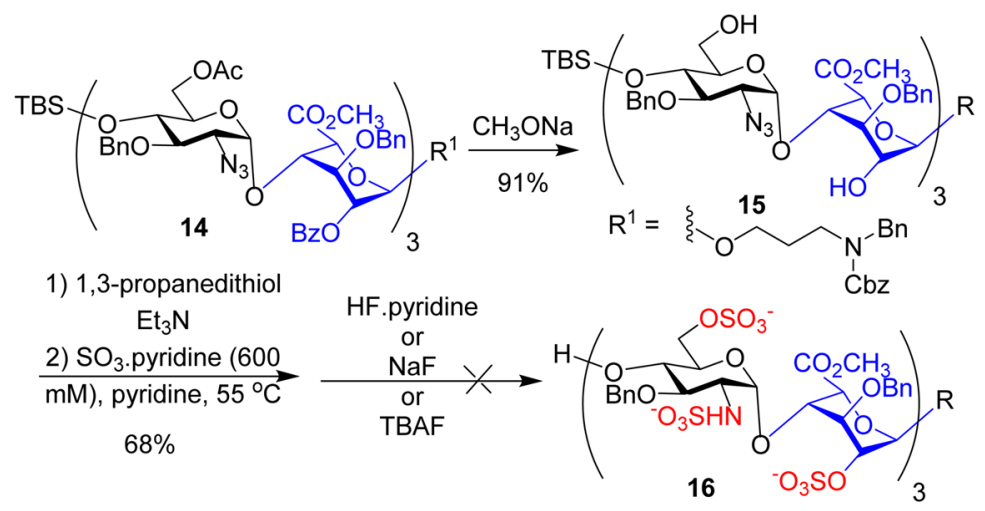

with sodium methoxide, producing hexa-ol $\mathbf{1 5}$ in $91 \%$ yield (Scheme 4). However, Staudinger reduction of the azides in $\mathbf{1 5}$ led to several products due to backbone cleavage. This is consistent with the previous observation that HS backbones bearing uronic esters were not stable under the Staudinger reduction conditions. ${ }^{25}$ Instead, the azides in $\mathbf{1 5}$ were transformed to amines with 1,3 -propanedithiol ${ }^{29}$ in $91 \%$ yield and the resulting amino alcohol was sulfated with $\mathrm{SO}_{3}$-pyridine. The subsequent removal of TBS turned out to be very challenging. HF.pyridine only partially cleaved TBS, while leading to the loss of sulfate groups from the molecule. Addition of pyridine to reduce the acidity of the reaction or performing the reaction at lower temperatures did not improve the result. The use of other fluoride sources such as $\mathrm{NaF}$ or 


\section{Scheme 5}

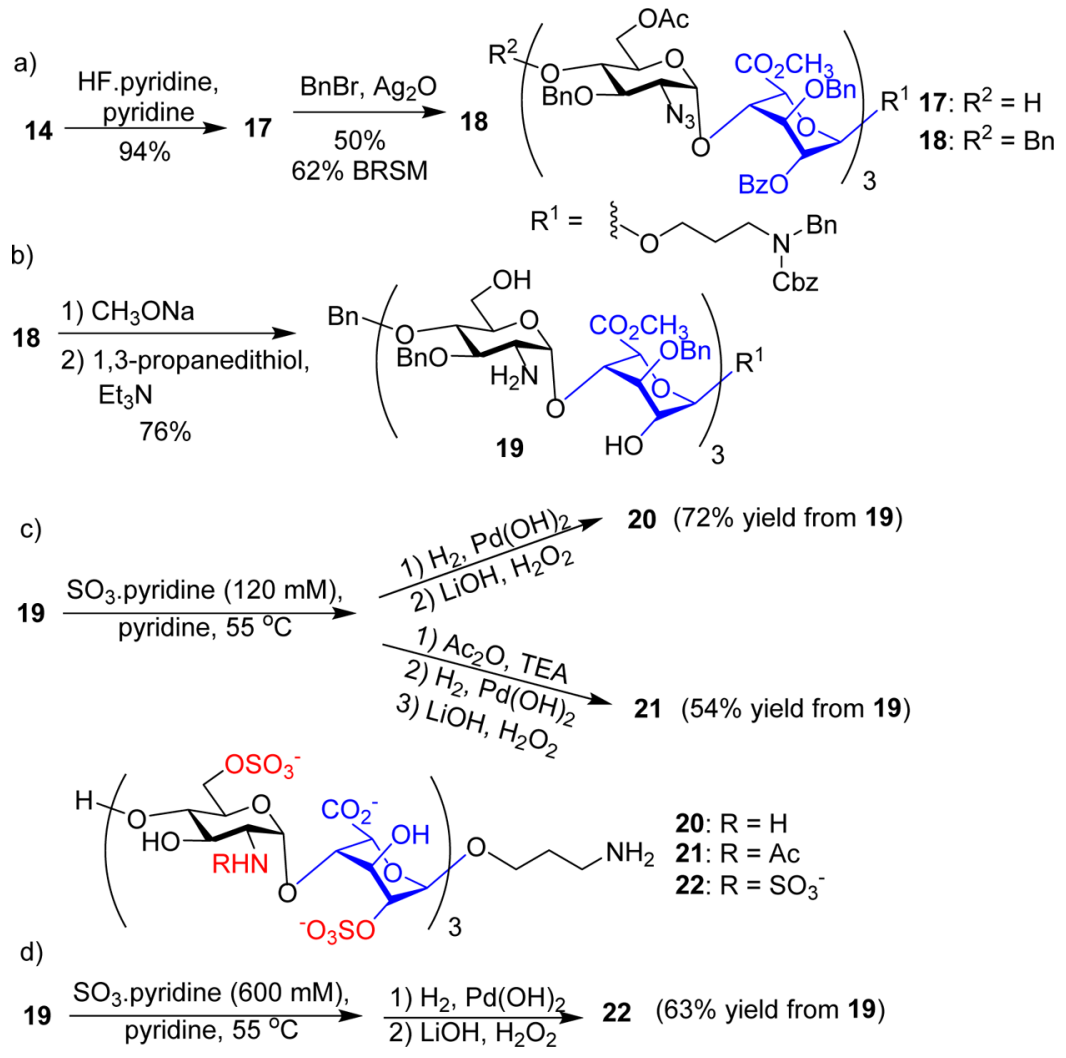

tetrabutylammonium fluoride (TBAF) was unsuccessful with the recovery of starting terial.

The difficulty in TBS deprotection from the highly sulfated hexasaccharide suggested that this transformation should be carried out earlier. Treatment of hexasaccharide 14 with HF-pyridine in pyridine removed the TBS group smoothly in 94\% yield (Scheme 5a). The hydroxyl group freed needed to be protected to avoid its sulfation. To differentiate this group from the hydroxyl groups to be sulfated, benzyl ether was used as the protective group. Benzylation of $\mathbf{1 7}$ under acidic conditions with benzyl 2,2,2-trichloroacetimidate ${ }^{52}$ was tested first. Despite multiple trials with several acid catalysts and reaction solvents, no desired benzylated hexasaccharide 18 was obtained. Next, the basic benzylation conditions with benzyl bromide and a host of bases were screened. Strong bases such as $\mathrm{NaH}$ and $\mathrm{NaHMDS}^{53}$ led to multiple products due to acyl migration. Finally, the hydroxyl group was successfully masked as a benzyl ether using benzyl bromide promoted by freshly prepared silver oxide, leading to hexasaccharide 18 in $50 \%$ yield (62\% based on recovered starting material) (Scheme $5 a$ ).

With the newly benzylated backbone 18, deprotection and sulfation were performed. The acyl protective groups in $\mathbf{1 8}$ were removed with sodium methoxide, which was followed by azide reduction with 1,3-propanedithiol (Scheme 5b). The resulting hexasaccharide 19 was subjected to sulfation. Interestingly, by controlling the amount of the sulfation agents, divergent sulfation could be achieved. Treatment of 19 with $\mathrm{SO}_{3}$.pyridine (120 mM, 24 equiv) at $55{ }^{\circ} \mathrm{C}$ for $24 \mathrm{~h}$ installed six $O$-sulfates without any $\mathrm{N}$-sulfates (Scheme 5c). This was presumably due to the protonation of the free amines under the slightly acidic reaction conditions, reducing their nucleophilicities. The $O$-sulfated hexasaccharide was hydrogenated to remove all benzyl ethers, and the methyl esters were cleaved, producing the fully deprotected HS hexasaccharide 20. Alternatively, the amines were acylated with acetic anhydride after sulfation of 19. Subsequent hydrogenolysis and ester cleavage generated the acetamide-containing hexasaccharide $\mathbf{2 1}$. In order to prepare the $\mathrm{N}$-sulfated sequence, 19 was treated with $600 \mathrm{mM}$ of $\mathrm{SO}_{3}$. pyridine, which was followed by catalytic hydrogenolysis and mild base hydrolysis, producing the $\mathrm{N}$ - and $\mathrm{O}$-sulfated hexasaccharide 22 with an overall yield of 63\% from 19 (Scheme 5d).

The dichotomy in the outcome of sulfation prompted further investigation. It should be pointed out that HS hexasaccharides or longer bearing free uronic acids have been successfully sulfated. ${ }^{12-20}$ However, in those cases, at most, two sulfates were installed per disaccharide unit, while, for 13, three sulfates would need to be introduced on each disaccharide. To better understand the structural requirements for chemical sulfation, the free uronic acid bearing tetrasaccharide $\mathbf{2 3}$ was synthesized from deprotection of tetrasaccharide 11, followed by sulfation (Scheme 6a). The successful generation of $\mathbf{2 3}$ combined with prior observations ${ }^{12-20}$ suggests that, for extensive sulfations (i.e., introduction of 3 sulfates including $\mathrm{N}$ - and $\mathrm{O}$-sulfates per disaccharide) of HS oligosaccharides longer than tetrasaccharides, it is crucial that the uronic acids are protected as carboxylic esters. ${ }^{29,36}$

Enzymatic Sulfation. To increase the sequence diversity that can be generated, hexasaccharide 24 bearing only $N$-sulfation was prepared from hexasaccharide 18 (Scheme 6b). Enzymatic sulfations of hexasaccharide $\mathbf{2 4}$ were explored with two main $\mathrm{O}$-sulfotransferases, namely, 2-OST and 6-OST. The enzymatic sulfation reactions were found to be sensitive to substrate concentration. Trials on backbone 24 using a combination of 6-OST-1 and 6-OST-3 in the presence of $3^{\prime}$-phosphoadenosine $5^{\prime}$-phosphosulfate (PAPS) as the sulfate donor proceeded 


\section{Scheme 6}
1) $\mathrm{NH}_{2}-\mathrm{NH}_{2}$, acetic acid, pyridine, $0^{\circ} \mathrm{C}$
a) 2) TEMPO, BAIB, ${ }^{\mathrm{B}} \mathrm{BuOH}$ $\mathrm{DCM} / \mathrm{H}_{2} \mathrm{O}$; then $\mathrm{PhCHN}$ 3) HF.pyridine, pyridine
11 4) $\mathrm{BnBr}, \mathrm{Ag}_{2} \mathrm{O}$
5) $\mathrm{CH}_{3} \mathrm{ONa}$; then 1,3-propanedithiol, $\mathrm{Et}_{3} \mathrm{~N}$ 6) $\mathrm{SO}_{3}$.pyridine $(600 \mathrm{mM})$, pyridine, $55^{\circ} \mathrm{C}$
7) $\mathrm{H}_{2}, \mathrm{Pd}(\mathrm{OH})_{2} ; \mathrm{LiOH}, \mathrm{H}_{2} \mathrm{O}_{2}$, then $\mathrm{KOH}$

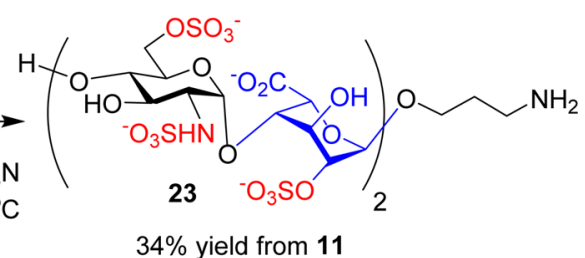
b)
18 2) $\mathrm{PMe}_{3}, \mathrm{NaOH}$
3) $\mathrm{SO}_{3} \cdot \mathrm{NEt}_{3}$ $\mathrm{NaOH}, \mathrm{CH}_{3} \mathrm{OH}$, rt
1) $\mathrm{LiOH}, \mathrm{H}_{2} \mathrm{O}_{2}$, then $\mathrm{KOH}$
4) $\mathrm{H}_{2}, \mathrm{Pd}(\mathrm{OH})_{2}$

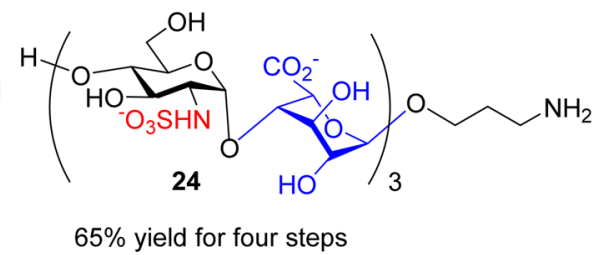

Scheme 7

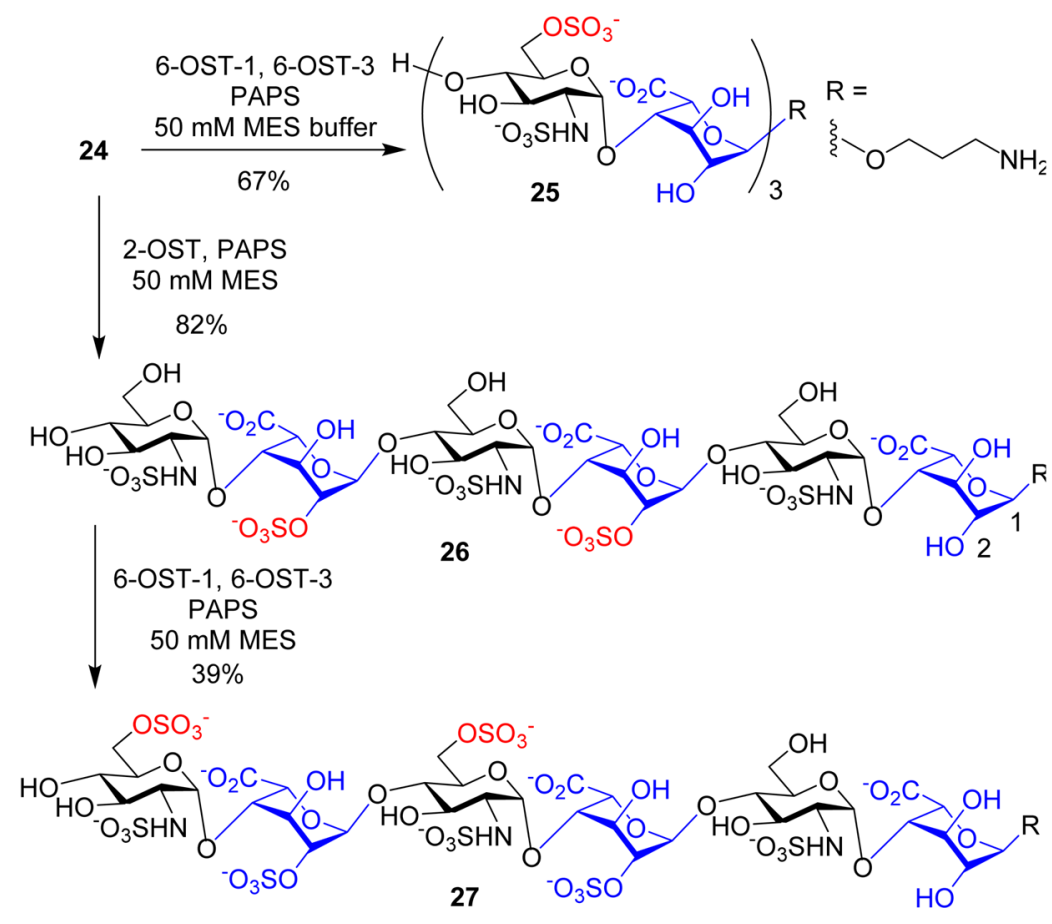

with very low yields when performed at a substrate concentration of $100 \mu \mathrm{g} / \mathrm{mL} .^{54}$ Diluting the reaction to a concentration of $50 \mu \mathrm{g} / \mathrm{mL}$ while maintaining the concentrations of enzymes, PAPS and buffer capacity enabled successful reaction (67\% isolated yield), producing hexasaccharide 25 bearing three $\mathrm{O}$-sulfates, indicating full 6-O sulfation (Scheme 7). Performing the reaction at a lower concentration presumably overcame product inhibition of enzymatic activities. Interestingly, when the reaction was stopped prior to completion, only hexasaccharides 24 and $\mathbf{2 5}$ were observed with no partially $O$-sulfated hexasaccharides in the reaction mixture based on mass spectrometry analysis. This is possibly because, once one $O$-sulfate was added, the subsequent sulfation reactions proceeded more readily.

To install the 2-O sulfates, 24 was treated with 2-OST and PAPS, which led to hexasaccharide $\mathbf{2 6}$ containing two additional sulfates in $82 \%$ yield. NMR analysis was performed on 26. Compared to 24, the chemical shifts of $\mathrm{H} 1$ and $\mathrm{H} 2$ of the reducing end iduronic acid of $\mathbf{2 6}$ were changed little with $\mathrm{H} 1$ appearing at $4.78 \mathrm{ppm}$ (vs $4.83 \mathrm{ppm}$ in 24$)$ and $\mathrm{H} 2$ at $3.58 \mathrm{ppm}$ (3.59 ppm for 24). The chemical shifts of the other two iduronic acid residues were significantly altered. Chemical shifts of $\mathrm{H}-1 \mathrm{~s}$ were shifted from $4.90 \mathrm{ppm}$ in 24 to $5.16 \mathrm{ppm}$ in 26 presumably due to the installation of electron-withdrawing $\mathrm{O}$-sulfates. $\mathrm{H} 2 \mathrm{~s}$ were more deshielded and both moved downfield from 3.64 to $4.22 \mathrm{ppm}$. On the basis of these observations, the structure of hexasaccharide 26 was assigned to contain $2-O$ sulfates on the nonreducing end and internal disaccharides. The fact that the reducing end iduronic acid is not modified in $\mathbf{2 6}$ suggests that 2-OST requires additional glycans at the reducing end of the iduronic acid to be sulfated.

Further elaborations of $\mathbf{2 5}$ and $\mathbf{2 6}$ were carried out. Treatment of the 6-O sulfate bearing hexasaccharide 25 with 2-OST only furnished the starting material, indicating that it is a poor substrate for 2-OST. When the 2-OST product $\mathbf{2 6}$ was treated with 6-OST and PAPS, the resulting hexasaccharide product $\mathbf{2 6}$ was found to contain two additional sulfates. Through NMR 

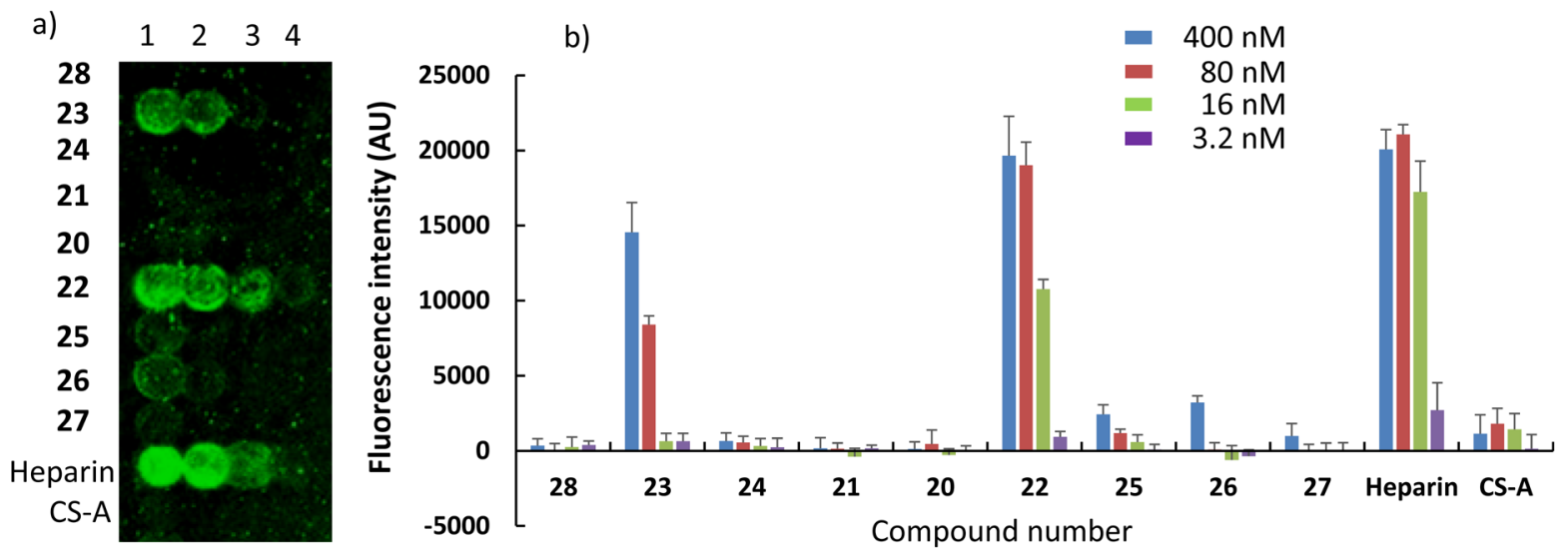

Figure 1. (a) A representative image of HS microarray upon incubation with FGF-2, which was detected by an anti-FGF2 IgG antibody, followed by a FITC labeled secondary antibody. Columns 1, 2, 3, and 4 represented spots printed with 400, 80, 16, and $3.2 \mathrm{nM}$ of glycans, respectively. (b) Quantification of the fluorescence signals from the microarray. Additional images are presented in the Supporting Information.

analysis, the H-6 protons of the glucosamine in the nonreducing and internal disaccharides of the product 27 were found to appear at 4.15 and $4.30 \mathrm{ppm}$, respectively. In contrast, those belonging to the reducing end disaccharide had chemical shifts of 3.60 and $3.72 \mathrm{ppm}$. Therefore, the $6-O$ sulfates of 27 were determined to be located on the nonreducing and internal disaccharide units. The 2-O sulfations in 26 directed the 6-OST to selectively modify the disaccharides already carrying 2-Osulfation. The results from these enzymatic sulfations suggest that, in biosynthesis of naturally existing HS, 2-O sulfation most likely precedes the installation of 6-O sulfates on the same disaccharide unit. This is consistent with the observations from enzymatic modification of HS polysaccharides. ${ }^{55}$

Hexasaccharides 24-27 contain three consecutive iduronic acid bearing disaccharides. This type of backbone structure is inaccessible through the current enzymatic synthesis strategy. At the same time, it should be pointed out that the disaccharide units in hexasaccharides $\mathbf{2 6}$ and $\mathbf{2 7}$ are not uniformly sulfated. To prepare these compounds via a pure chemical approach, a new disaccharide module with the potential $O$-sulfation sites blocked by protective groups different from those in disaccharide 1 must be prepared, which would increase the total number of synthetic steps. Thus, the combination of chemical synthesis with enzymatic modification improves the overall synthetic efficiencies.

Higher Sulfation and Longer Backbone Enhance HS Binding with FGF-2. In order to probe the effects of length and sulfation pattern of synthetic HS oligosaccharides on their biological properties, their bindings with FGF-2 were investigated. FGF-2 is an important protein involved in angiogenesis, cell proliferation, and tumor development. ${ }^{56,57}$ Through direct FGF-2 binding, HS and its highly sulfated form heparin are known to play a central role in regulating FGF-2 activities. ${ }^{58}$

To increase the speed of analysis of FGF-2 binding, the glycan microarray technology was utilized, ${ }^{59-62}$ which is a powerful technique for analyzing carbohydrate-protein interactions including HS studies. ${ }^{19,63,64}$ As all synthetic HS glycans bear amino moieties at their respective reducing ends, the glycans were printed onto an $\mathrm{N}$-hydroxysuccinimide (NHS) ester functionalized glass slide to covalently immobilize the glycans through amide bonds. Furthermore, serial dilutions of each HS oligosaccharide (from 400 to $3.2 \mathrm{nM}$ ) were printed onto the microarray for semiquantitative analysis of the affinity. The unreacted NHS esters were quenched with ethanolamine.
HS disaccharide 28, heparin, and chondroitin sulfate A (CS-A) polysaccharides were also added to the slides at the same concentrations.

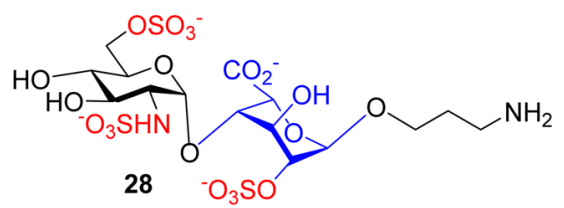

The HS slides were incubated with a solution of FGF-2, followed by washing to remove the unbound protein. The slides were subsequently treated with a fluorescein isothiocyanate (FITC) labeled anti-FGF-2 antibody. The binding of FGF-2 with an HS oligosaccharide would enable the immobilization of the anti FGF-2 antibody on the array and allow its detection by fluorescence. Slides from multiple sources were examined, and those from Xantec Bioanalytics were found to give the highest signal-to-noise ratio and most reproducible results in our hands. As shown in Figure 1, the spots with immobilized heparin polysaccharide exhibited intense signals, indicating strong binding between heparin and FGF-2. In contrast, despite the presence of multiple sulfates, CS-A polysaccharide gave little signals, suggesting that the nonspecific electrostatic interactions between a cluster of negative charges on the microarray surface and FGF-2 most likely do not play important roles in FGF-2 binding to array components. Similar phenomena have been observed previously. ${ }^{62}$

Comparisons of the fluorescence signals from the oligosaccharides on the array revealed HS structural impact on binding. Disaccharide 28, tetrasaccharide 23, and hexasaccharide 22 all bear full $\mathrm{N}-$, 2-O, and 6-O sulfations. Whereas disaccharide $\mathbf{2 8}$ did not bind much with FGF-2, tetrasaccharide 23 and hexasaccharide 22 exhibited strong binding, with the signal intensities of 22 approaching those of heparin polysaccharides (Figure $1 \mathrm{~b}$ ). This suggested that tetrasaccharide is the minimum length for strong binding in this assay. ${ }^{65}$ Previously, an HS disaccharide similar to 28 was shown to bind with FGF-2, ${ }^{19}$ which was most likely due to the higher glycan concentrations ( $16 \mu \mathrm{M}$ to $2 \mathrm{mM}$ ) utilized in that study.

The number of sulfates and backbone sequence are important factors in FGF-2 binding. The seven HS hexasaccharides (20-22, 24-27) contain small variations in the number of sulfates. However, based on the array signals, 22 exhibited the strongest binding to FGF-2, suggesting that full 2-O, 6-O, and 
$\mathrm{N}$-sulfations are important with the lack of any sulfation, leading to significant reduction in binding. It is interesting that, although 27 contains the full structure of tetrasaccharide 23 , its binding with FGF-2 was much weaker. This indicates that the reducing end disaccharide without any $O$-sulfations in $\mathbf{2 7}$ was detrimental to binding. The knowledge gained through the microarray studies can be helpful to guide future design of HS oligosaccharide based probes to modulate FGF-2 activities.

\section{CONCLUSIONS}

We report a divergent methodology allowing the access to seven HS hexasaccharides from a single common hexasaccharide precursor. An efficient chemical glycosylation strategy was developed to prepare the HS tetra- and hexasaccharide backbones. Difficulties were encountered in chemical sulfation and deprotection of the hexasaccharide. The substrate structure and concentration of the sulfation agent were found to be crucial for successful sulfations. To enhance sequence diversity, chemically synthesized HS hexasaccharide backbones were enzymatically sulfated. Besides synthetic utilities, the welldefined oligosaccharide structures helped shine light on the fine substrate specificities of the 6-OST and 2-OST and confirm the potential sequence of enzymatic reactions in HS biosynthesis. The synthetic HS oligosaccharides were then immobilized onto an HS oligosaccharide microarray, which was used to decipher the impacts of HS structures on FGF-2 binding. Both high sulfation and longer sequences were found to enhance the affinity with FGF-2. Further studies are ongoing to expand this divergent strategy in order to access a wide range of HS structures.

\section{EXPERIMENTAL SECTION}

General Experimental Procedures. All reactions were performed under a nitrogen atmosphere with anhydrous solvents. Solvents were dried using a solvent purification system. Glycosylation reactions were performed with $4 \AA$ molecular sieves that were flamed-dried under high vacuum. Chemicals used were reagent grade unless noted. Reactions were visualized by UV light $(254 \mathrm{~nm})$ and by staining with either $\mathrm{Ce}\left(\mathrm{NH}_{4}\right)_{2}\left(\mathrm{NO}_{3}\right)_{6}(0.5 \mathrm{~g})$ and $\left(\mathrm{NH}_{4}\right)_{6} \mathrm{Mo}_{7} \mathrm{O}_{24} \cdot 4 \mathrm{H}_{2} \mathrm{O}(24.0 \mathrm{~g})$ in $6 \%$ $\mathrm{H}_{2} \mathrm{SO}_{4}(500 \mathrm{~mL}), 5 \% \mathrm{H}_{2} \mathrm{SO}_{4}$ in $\mathrm{EtOH}$, or, for deprotected oligosaccharides, $0.2 \mathrm{~g}$ of 1,3-dihyroxynaphthalene in $50 \mathrm{~mL}$ of $5 \%$ $\mathrm{H}_{2} \mathrm{SO}_{4}$ in EtOH. Flash chromatography was performed on silica gel 601 (230-400 Mesh). NMR spectra were referenced using residual $\mathrm{CHCl}_{3}$ $\left(\delta{ }^{1} \mathrm{H}\right.$ NMR 7.26 PPM ${ }^{13} \mathrm{C}$ NMR 77.0 PPM). Peak and coupling constants assignments are based on ${ }^{1} \mathrm{H}$ NMR, ${ }^{1} \mathrm{H}-{ }^{1} \mathrm{H}$ gCOSY, ${ }^{1} \mathrm{H}$ and ${ }^{1} \mathrm{H}-{ }^{1} \mathrm{H}$ TOCSY, ${ }^{1} \mathrm{H}-{ }^{1} \mathrm{H}$ NOESY, ${ }^{1} \mathrm{H}-{ }^{13} \mathrm{C}$ gHMQC $/{ }^{1} \mathrm{H}-{ }^{13} \mathrm{C}$ HSQC, and ${ }^{1} \mathrm{H}-{ }^{13} \mathrm{C}$ gHMBC. For NMR assignments, the glycosyl units in an oligosaccharide were designated as A, B, C, D, E, and F sequentially where necessary from the reducing end to the nonreducing end.

Characterization of Anomeric Stereochemistry. The stereochemistries of newly formed glycosidic bonds for idose and glucosamine were determined by ${ }^{3} J_{\mathrm{H} 1, \mathrm{H} 2}$ through ${ }^{1} \mathrm{H}$ NMR and/or ${ }^{1} J_{\mathrm{C} 1, \mathrm{H} 1}$ through gHMQC 2-D NMR (without ${ }^{1} \mathrm{H}$ decoupling). Smaller ${ }^{3} J_{\mathrm{H} 1, \mathrm{H} 2}(3 \mathrm{~Hz})$ indicate $\alpha$ linkages, and larger ${ }^{3} J_{\mathrm{H} 1, \mathrm{H} 2}(7 \mathrm{~Hz}$ or larger) indicate $\beta$ linkages. ${ }^{1} J_{\mathrm{C} 1, \mathrm{H} 1}$ coupling constants around $170 \mathrm{~Hz}$ suggest $\alpha$ linkages, whereas values around $160 \mathrm{~Hz}$ imply $\beta$ linkages. ${ }^{48}$

General Procedure for Preactivation Based Glycosylation. A solution of donor $(60 \mu \mathrm{mol})$ and freshly activated $4 \AA$ molecular sieves $\left(200 \mathrm{mg}\right.$ ) in $\mathrm{CH}_{2} \mathrm{Cl}_{2}$ was stirred at room temperature for $30 \mathrm{~min}$ and then cooled to $-78^{\circ} \mathrm{C}$. $\operatorname{AgOTf}(31 \mathrm{mg}, 120 \mu \mathrm{mol})$ dissolved in $\mathrm{Et}_{2} \mathrm{O}$ was added directly to the solution making sure the solution did not touch the walls of the flask. After $5 \mathrm{~min}$, orange-colored $p$-TolSCl $(9.5 \mu \mathrm{L}$, $60 \mu \mathrm{mol}$ ) was added via a microsyringe directly to the flask, as the reaction temperature was lower than the freezing point of $p$-TolSCl and it would freeze on the walls of the flask. The color of $p$-TolSCl disappeared rapidly, indicating the consumption of $p$-TolSCl. After the donor was completely consumed, as verified by TLC analysis (about $5 \mathrm{~min}$ at $-78^{\circ} \mathrm{C}$ ), a solution of acceptor $(54 \mu \mathrm{mol})$ in $\mathrm{CH}_{2} \mathrm{Cl}_{2}$ $(1 \mathrm{~mL})$ along with 1 equiv of TTBP was slowly added dropwise along the walls of the flask. This was done to allow the acceptor solution to cool before mixing with the activated donor. The reaction mixture was warmed to $0{ }^{\circ} \mathrm{C}$ under stirring in around $2 \mathrm{~h}$. The mixture was diluted with $\mathrm{CH}_{2} \mathrm{Cl}_{2}$ and filtered through Celite. After washing the Celite with $\mathrm{CH}_{2} \mathrm{Cl}_{2}$ until all organic compounds were removed, as verified by TLC, the $\mathrm{CH}_{2} \mathrm{Cl}_{2}$ fractions were combined and washed twice with a saturated aqueous solution of $\mathrm{NaHCO}_{3}(20 \mathrm{~mL})$, and twice with water $(10 \mathrm{~mL})$. The organic layer was collected and dried over $\mathrm{Na}_{2} \mathrm{SO}_{4}$. After removal of the solvent, the product was purified by silica gel flash chromatography unless noted.

General Procedure for TBS Removal. The TBS-containing oligosaccharide $(0.54 \mathrm{mmol})$ was transferred to a $50 \mathrm{~mL}$ plastic centrifuge tube by three portions of $3.33 \mathrm{~mL}$ of pyridine. While stirring, the pyridine solution was cooled to $0{ }^{\circ} \mathrm{C}$. Then, $5 \mathrm{~mL}$ of HF.pyridine was added dropwise to the stirring solution. The reaction was then allowed to warm to room temperature and kept overnight. After verifying that the reaction was complete by TLC, the reaction was diluted with $\mathrm{CH}_{2} \mathrm{Cl}_{2}$ and washed sequentially with sat. $\mathrm{CuSO}_{4}$, sat. $\mathrm{NaHCO}_{3}$, and $10 \% \mathrm{HCl}$. The organic layer was dried over $\mathrm{Na}_{2} \mathrm{SO}_{4}$, concentrated, and purified by silica gel flash chromatography.

General Procedure for Benzylation. The oligosaccharide to be protected $(15 \mu \mathrm{mol})$ was dissolved in $5 \mathrm{~mL}$ of $\mathrm{CH}_{2} \mathrm{Cl}_{2}$. To this solution were added TBAI (1 equiv), benzyl bromide (40 equiv), and freshly prepared $\mathrm{Ag}_{2} \mathrm{O}$ (20 equiv). The reaction was stirred at room temperature until TLC indicated that the reaction was no longer progressing (30 min). The reaction was quenched by diluting with $\mathrm{CH}_{2} \mathrm{Cl}_{2}$ and filtering through Celite to remove $\mathrm{Ag}_{2} \mathrm{O}$. The reaction was concentrated and purified by silica gel chromatography.

General Procedure for Levulinoyl Ester Formation. A mixture of the oligosaccharide (1 mmol), 1-ethyl-3-(3-(dimethylamino)propyl)carbodiimide hydrochloride (EDC. $\mathrm{HCl} 3.3$ equiv per $\mathrm{OH}$ ), and $\mathrm{N}, \mathrm{N}$-dimethylaminopyridine (DMAP, 0.1 equiv per $\mathrm{OH}$ ) was dissolved in dichloromethane (DCM, $30 \mathrm{~mL})$. To this solution was added levulinic acid (3 equiv per $\mathrm{OH}$ ), and the reaction was stirred at room temperature overnight. The mixture was then diluted with DCM, washed with sat. $\mathrm{NaHCO}_{3}$, dried over $\mathrm{Na}_{2} \mathrm{SO}_{4}$, concentrated, and purified by flash silica gel chromatography.

General Procedure for Removal of Levulinoyl Esters. A solution of the oligosaccharide containing Lev esters $(56 \mu \mathrm{mol})$ in $2.4 \mathrm{~mL}$ of pyridine and $1.6 \mathrm{~mL}$ of glacial acetic acid was cooled to $0{ }^{\circ} \mathrm{C}$. To this was added $27 \mu \mathrm{L}$ of hydrazine hydrate $(560 \mu \mathrm{mol}$ or 5 equiv per Lev ester). The reaction was stirred at $0{ }^{\circ} \mathrm{C}$ for $3 \mathrm{~h}$ or until TLC shows that the reaction is complete. To quench the reaction, $1 \mathrm{~mL}$ of acetone was added and the reaction was stirred at room temperature for $30 \mathrm{~min}$. The reaction mixture was then diluted with ethyl acetate and washed with $25 \mathrm{~mL}$ each of the following solutions: sat. $\mathrm{NaHCO}_{3}, 10 \% \mathrm{HCl}$, $\mathrm{H}_{2} \mathrm{O}$, and brine. The resulting organic layer was then dried over $\mathrm{Na}_{2} \mathrm{SO}_{4}$, concentrated, and purified by silica gel flash chromatography.

General Procedure for Oxidation of $6-\mathrm{OH}$. The desired compound to be oxidized ( $45 \mu \mathrm{mol})$ was dissolved in a solution of $2 \mathrm{~mL}$ of DCM, $2 \mathrm{~mL}$ of $t \mathrm{BuOH}$, and $0.5 \mathrm{~mL}$ of $\mathrm{H}_{2} \mathrm{O}$. To this solution was added TEMPO ( $26.5 \mu \mathrm{mol}$ or 0.3 equiv per $6-\mathrm{OH})$, followed by BAIB (221 $\mu \mathrm{mol}$ or 2.5 equiv per $6-\mathrm{OH})$. The reaction was then stirred at room temperature overnight. After ensuring that the reaction was complete by TLC ( $1 \%$ acetic acid in ethyl acetate), the reaction was quenched by addition of $2 \mathrm{~mL}$ of $\mathrm{Na}_{2} \mathrm{~S}_{2} \mathrm{O}_{3}$ solution and allowed to stir at room temperature for $15 \mathrm{~min}$. The mixture was then diluted with $10 \mathrm{~mL}$ of DCM and $3 \mathrm{~mL}$ of $\mathrm{H}_{2} \mathrm{O}$ and separated. The aqueous layer was acidified with $1 \mathrm{M} \mathrm{HCl}$ solution and extracted three times with DCM. The organic layers were combined, dried over $\mathrm{Na}_{2} \mathrm{SO}_{4}$, and concentrated. The crude product could then be protected as a benzyl or methyl ester.

General Procedure for Benzyl Ester Formation after Oxidation. The crude product from oxidation was dissolved in $5 \mathrm{~mL}$ of DCM. To this was added phenyl diazomethane until a deep red color persisted. ${ }^{66}$ The reaction was allowed to stir overnight. After TLC indicated that the reaction was complete, the mixture was concentrated and purified by column chromatography. 
General Procedure for Methyl Ester Formation after Oxidation. The crude product from oxidation was dissolved in DMF ( $2 \mathrm{~mL}$ for $15 \mu \mathrm{mol}$ ). To this solution was added $\mathrm{K}_{2} \mathrm{CO}_{3}$ ( 5 equiv per $\mathrm{COOH})$, followed by $\mathrm{CH}_{3} \mathrm{I}(2.5$ equiv per $\mathrm{COOH}$ ), and the reaction was allowed to stir overnight at room temperature. After verifying that the reaction was complete by TLC, the reaction was diluted with ethyl acetate and water. The mixture was then washed with $0.1 \mathrm{M} \mathrm{HCl}$, followed by sat. $\mathrm{NaHCO}_{3}$, dried over $\mathrm{Na}_{2} \mathrm{SO}_{4}$, concentrated, and purified by flash silica gel chromatography.

General Procedure for Saponification. The mixture of compound (for $100 \mathrm{mg}$ of compound, 1 equiv), THF $(2.5 \mathrm{~mL})$, and $1 \mathrm{M} \mathrm{LiOH}$ (13 equiv per COOBn) was cooled to $0{ }^{\circ} \mathrm{C}$, followed by addition of $\mathrm{H}_{2} \mathrm{O}_{2}$ (150 equiv per $\mathrm{COOBn}, 30 \%$ ). The mixture was stirred at room temperature for $16 \mathrm{~h}$, and then methanol $(6 \mathrm{~mL})$ and $3 \mathrm{M}$ potassium hydroxide ( 80 equiv per $\mathrm{COOBn}$ ) were added to the solution. The mixture was stirred for another $24 \mathrm{~h}$, then acidified with $10 \% \mathrm{HCl}$, and concentrated to dryness. The resulting residue was purified by quickly passing through a short silica gel column (4:1, DCM:MeOH).

General Procedure for Transesterification. The methyl ester containing oligosaccharide $(10 \mu \mathrm{mol})$ was dissolved in $2 \mathrm{~mL}$ of dry DCM and $2 \mathrm{~mL}$ of anhydrous methanol. The two solvents were dried over $4 \AA$ molecular sieves for $24 \mathrm{~h}$. A sodium methoxide solution was made by adding sodium to a portion of anhydrous methanol. This fresh sodium methoxide solution was added to the oligosaccharide solution until the $\mathrm{pH}$ reached 12 . The reaction was maintained at $\mathrm{pH}=12$ and stirred at room temperature for $2 \mathrm{~h}$. After the reaction was confirmed complete by TLC, it was quenched to $\mathrm{pH}=7$ by a $1 \mathrm{M}$ acetic acid solution in dry methanol. The quenched reaction was concentrated and purified by silica gel chromatography.

General Procedure for Staudinger Reduction. $1 \mathrm{M} \mathrm{PMe}_{3}$ solution in THF (5 equiv per $\mathrm{N}_{3}$ ), $0.1 \mathrm{M}$ aqueous solution of $\mathrm{NaOH}$ ( 3 equiv per $\mathrm{N}_{3}$ ), and $\mathrm{H}_{2} \mathrm{O}(2 \mathrm{~mL})$ were added consecutively to a solution of azide-containing compound (for $50 \mathrm{mg}$ of compound, 1 equiv) in THF $(7 \mathrm{~mL})$. The mixture was stirred at room temperature overnight and neutralized with $0.1 \mathrm{M} \mathrm{HCl}$ until $\mathrm{pH}=7$. The mixture was concentrated to dryness, and the resulting residue was purified with Sephadex LH-20 (50/50 DCM/MeOH).

General Procedure for 1,3-Dithiopropane Mediated Azide Reduction. The starting oligosaccharide was dissolved in anhydrous $\mathrm{MeOH}$ (dried over $4 \AA$ molecular sieves) and protected from light. To this solution were added triethylamine $\left(6.7\right.$ equiv per $\mathrm{N}_{3}$ ) and 1,3-dithiopropane (6.7 equiv per $\mathrm{N}_{3}$ ), and the reaction was stirred at room temperature for $24 \mathrm{~h}$. After 1 day, additional portions of triethylamine and 1,3-dithiopropane (6.7 equiv per $\mathrm{N}_{3}$ of each) were added, and the reaction was stirred for another $72 \mathrm{~h}$. The reaction was diluted with a 1:1 mixture of $\mathrm{DCM}: \mathrm{MeOH}$ and was layered onto a Sephadex LH-20 column and eluted with 1:1 DCM:MeOH.

General Procedure for $\mathbf{O}$-Sulfation. The mixture of $\mathrm{OH}$ containing compound (for $5 \mathrm{mg}$ of compound, 1 equiv), DMF ( $1 \mathrm{~mL}$ dried over $4 \AA$ molecular sieves), and $\mathrm{SO}_{3} \cdot \mathrm{NEt}_{3}$ (5 equiv per $\mathrm{OH}$ ) was stirred at $55{ }^{\circ} \mathrm{C}$ for $24 \mathrm{~h}$. The mixture was quenched by adding $\mathrm{NEt}_{3}(0.2 \mathrm{~mL})$ and then diluted with $\mathrm{DCM} / \mathrm{MeOH}(1 \mathrm{~mL}: 1 \mathrm{~mL})$. The resulting solution was layered on the top of a Sephadex LH-20 chromatography column that was eluted with DCM/MeOH $(1: 1)$.

General Procedure for $\mathrm{N}$-Sulfation. A mixture of $\mathrm{NH}_{2}$-containing compound (for $5 \mathrm{mg}$ of compound, 1 equiv), pyridine ( $1 \mathrm{~mL}$ dried over $4 \AA$ molecular sieves), $\mathrm{Et}_{3} \mathrm{~N}\left(0.2 \mathrm{~mL}\right.$ ), and $\mathrm{SO}_{3}$.pyridine (5 equiv per $\mathrm{NH}_{2}$ ) was stirred at room temperature for $3 \mathrm{~h}$. The mixture was diluted with $\mathrm{DCM} / \mathrm{MeOH}(1 \mathrm{~mL} / 1 \mathrm{~mL})$, and the resulting solution was layered on the top of a Sephadex LH-20 chromatography column that was eluted with $\mathrm{DCM} / \mathrm{MeOH}(1 / 1)$.

General Procedure for Global Debenzylation. A mixture of the Bn-containing compound (for $6 \mathrm{mg}$ of compound, 1 equiv), $\mathrm{MeOH} /$ $\mathrm{H}_{2} \mathrm{O}(4 \mathrm{~mL} / 2 \mathrm{~mL})$, and $\mathrm{Pd}(\mathrm{OH})_{2}$ on carbon $(100 \mathrm{mg})$ was stirred under $\mathrm{H}_{2}$ at room temperature overnight and then filtered. The filtrate was concentrated to dryness under vacuum and then diluted with $\mathrm{H}_{2} \mathrm{O}(15 \mathrm{~mL})$. The aqueous phase was further washed with $\mathrm{CH}_{2} \mathrm{Cl}_{2}$ $(3 \times 5 \mathrm{~mL})$ and EtOAc $(3 \times 5 \mathrm{~mL})$, and then the aqueous phase was dried under vacuum. The crude product was further purified by size exclusion chromatography (G-15) and, for final compounds, then eluted from a column of Dowex 50WX4- $\mathrm{Na}^{+}$to convert the compound into the sodium salt form.

General Procedure for Selective $\mathrm{O}$-Sulfation. A compound ( $8 \mathrm{mg}$ or $4 \mu \mathrm{mol}$ ) containing both free $\mathrm{OH}$ and $\mathrm{NH}_{2}$ groups was dissolved in $1 \mathrm{~mL}$ of dry pyridine (dried over $4 \AA$ molecular sieves). To this mixture was added $20 \mathrm{mg}$ of $\mathrm{SO}_{3} \cdot$ pyridine $(120 \mathrm{mM})$. The sulfating agent had been previously washed with $\mathrm{H}_{2} \mathrm{O}, \mathrm{MeOH}$, and DCM and dried under vacuum. The reaction was protected from light and stirred for $24 \mathrm{~h}$ at $55{ }^{\circ} \mathrm{C}$. The reaction was diluted with $1: 1$ DCM:MeOH and eluted from a Sephadex LH-20 column, ensuring that all pyridine was removed. The fractions containing sugar were concentrated and further purified by prep TLC (3:1:1 EtOAC:MeOH: $\mathrm{H}_{2} \mathrm{O}$ $1 \% \mathrm{AcOH}$ ).

General Procedure for Simultaneous $\mathrm{O}, \mathrm{N}$-Sulfation. A compound ( $8 \mathrm{mg}$ or $4 \mu \mathrm{mol}$ ) containing both free $\mathrm{OH}$ and $\mathrm{NH}_{2}$ groups was dissolved in $1 \mathrm{~mL}$ of dry pyridine (dried over $4 \AA$ molecular sieves). To this mixture was added $100 \mathrm{mg}$ of $\mathrm{SO}_{3}$.pyridine $(600 \mathrm{mM})$. The sulfating agent had been previously washed with $\mathrm{H}_{2} \mathrm{O}, \mathrm{MeOH}$, and DCM and dried under vacuum. The reaction was protected from light and stirred for $24 \mathrm{~h}$ at $55{ }^{\circ} \mathrm{C}$. The reaction was diluted with $1: 1$ DCM:MeOH and eluted from a Sephadex LH-20 column, ensuring that all pyridine was removed. The fractions containing sugar were concentrated and further purified by prep TLC (3:1:1 EtOAC:MeOH: $\mathrm{H}_{2} \mathrm{O}$ $1 \% \mathrm{AcOH}$ )

General Procedure for Methyl Ester Saponification. The compound to be saponified was dissolved in $\mathrm{H}_{2} \mathrm{O}(1 \mathrm{~mL}$ for $5 \mathrm{mg}$ ), and $1 \mathrm{M} \mathrm{LiOH}$ (15 equiv per ester) was added. The mixture was cooled to $0{ }^{\circ} \mathrm{C}$. This was followed by addition of $\mathrm{H}_{2} \mathrm{O}_{2}$ ( 150 equiv per ester, $30 \%$ ), and the reaction was allowed to warm to room temperature and stir overnight. The reaction was neutralized with $1 \mathrm{M} \mathrm{AcOH}$ and eluted from a Sephadex G-15 column with $\mathrm{H}_{2} \mathrm{O}$. To simplify mass spectrometry analysis, the product was then eluted from a column of Dowex 50WX4- $\mathrm{Na}^{+}$to convert the compound into the sodium salt form.

General Procedure for Enzymatic Sulfation. The oligosaccharide to be sulfated $(500 \mu \mathrm{g}$ or $0.4 \mu \mathrm{mol})$ was mixed with $1 \mathrm{mg}$ of the needed enzyme(s) in $12.5 \mathrm{~mL}$ of solution. This solution had a concentration of $20 \mathrm{mM} 2$-( $\mathrm{N}$-morpholino)ethanesulfonic acid (MES) and $0.05 \mathrm{mg} / \mathrm{mL}$ of PAPS. This reaction was stirred at $37^{\circ} \mathrm{C}$ overnight. Another $1 \mathrm{mg}$ of the needed enzyme(s) was added, and the reaction was diluted to $25 \mathrm{~mL}$, keeping the concentration of MES at $20 \mathrm{mM}$ and PAPS at $0.05 \mathrm{mg} / \mathrm{mL}$, respectively. After another $24 \mathrm{~h}$ at $37^{\circ} \mathrm{C}$, the reaction was stopped. It was concentrated by utilizing a Q-Sepharose Fast Flow column. The mixture was passed through the column, which was then washed with $20 \mathrm{~mL}$ of $25 \mathrm{mM} \mathrm{NaOAc}$. The product was then eluted from the column with a solution of $1 \mathrm{M} \mathrm{NaCl}$ and $25 \mathrm{mM}$ $\mathrm{NaOAc}$. The product eluted within the first $2 \mathrm{~mL}$, and the column was further washed with $10 \mathrm{~mL}$ of the elution solution and $25 \mathrm{~mL}$ of the $25 \mathrm{mM} \mathrm{NaOAc}$ solution. The fractions containing sugar were lyophilized and loaded onto a P-2 column $(2 \mathrm{~m} \times 0.75 \mathrm{~cm}$ diameter $)$ with $1 \mathrm{~mL}$ of $0.1 \mathrm{M} \mathrm{NH}_{4} \mathrm{HCO}_{3}$. Additional $\mathrm{NH}_{4} \mathrm{HCO}_{3}$ was added until the loading solution was neutralized. An indicator, Phenol red $(5 \mu \mathrm{L})$, was added to monitor the column, and the product was eluted with $0.1 \mathrm{M} \mathrm{NH}_{4} \mathrm{HCO}_{3}$. Tubes containing product were lyophilized at least 3 times to remove any residual $\mathrm{NH}_{4} \mathrm{HCO}_{3}$ to allow for mass spectrometry analysis.

General Procedure for Microarray Preparation. All solutions were prepared with nanopure water. Recombinant human basic Fibroblast Growth Factor (FGF-2) and rabbit antihuman FGF-2 were purchased from PeproTech (Rocky Hill, NJ), and Cy5 conjugated goat ant-rabbit IgG $(\mathrm{H}+\mathrm{L})$ was purchased from Life Technologies (Grand Island, NY). NHS coated slides (SL HCX) were purchased from Xantec Bioanalytics $\mathrm{GmbH}$ (Germany). Microarrays were produced using a PixSys 5500 robotic printer (Cartesian Technologies Inc., California). Oligosaccharides were dissolved in $50 \mathrm{mM}$ sodium phosphate buffer $(\mathrm{pH}=9)$ and mechanically printed onto the NHS coated slides at $50 \%$ relative humidity and room temperature. After printing, slides were incubated at $75 \%$ humidity and room temperature overnight. Oligosaccharides were printed in four concentrations $(400,80,16$, and $3.2 \mathrm{nM}$ ), and each spot was replicated four times. Two natural sources 
were printed alongside the synthesized oligosaccharides. Heparin (HP, sodium salt, average molecular weight $18 \mathrm{kDa}, 177 \mathrm{USP}$ unit/mg) and Chondroitin sulfate A (sodium salt from bovine trachea average molecular weight $50 \mathrm{kDa}$ ) were both purchased from Sigma-Aldrich and printed in the same concentration as synthesized oligosaccharides using their average molecular weights. Slides were washed three times with water. To quench unreacted NHS groups, the slides were then incubated in a preheated $50{ }^{\circ} \mathrm{C}$ solution of $100 \mathrm{nM}$ ethanolamine in sodium phosphate buffer $(50 \mathrm{mM}, \mathrm{pH}=9)$ for $1 \mathrm{~h}$. After quenching, the slides were washed three times with water, dried by centrifugation $(2000 \mathrm{rpm}$ for $2 \mathrm{~min}$ ), and stored in a desiccator at $-5{ }^{\circ} \mathrm{C}$ until use. For all protein incubations, Lifterslips from Thermo Scientific were used in concert with $20 \mu \mathrm{L}$ of solution. Analysis of slides was done on an Agilent G2565AA Array Scanner.

General Procedure for Microarray Binding Assay. Slides to be used were warmed to room temperature before removing from the desiccator. Protein solutions were prepared by diluting stock solutions to concentrations of $8 \mu \mathrm{g} / \mathrm{mL}$ with PBS buffer $(10 \mathrm{mM} \mathrm{pH}=7.5)$ containing $1 \%$ BSA. An assay was run as follows. Slides were incubated with $20 \mu \mathrm{L}$ of FGF-2 solution (placed between Lifterslip and slide) and incubated in a microarray cassette at room temperature protected from light for $1 \mathrm{~h}$. After $1 \mathrm{~h}$, the slide was washed once with a solution of PBS $(10 \mathrm{mM} \mathrm{pH}=7.5)$ with $1 \%$ Tween-20 and $0.1 \%$ BSA and twice with water. The slide was dried by centrifugation, then incubated with $20 \mu \mathrm{L}$ of rabbit anti-Human FGF-2 for $1 \mathrm{~h}$ as done previously. The slide was then washed in the same way and finally incubated with $20 \mu \mathrm{L}$ of the secondary antibody Cy5 goat antirabbit IgG for $1 \mathrm{~h}$ and washed. After drying by centrifugation, the slide was imaged on an Agilent G2565AA Array Scanner. The intensities of the bands were quantified using ImageJ software.

p-Tolyl 6-O-Acetyl-2-azido-3-O-benzyl-4-O-tert-butyldimethylsilyl-2-deoxy- $\alpha$-D-glucopyranosyl- $(1 \rightarrow 4)$-2-O-benzoyl-3-O-benzyl-6levulinoyl-1-thio- $\alpha$-L-idopyranoside (1). Compound 1 was synthesized from 6 in two steps. First, $6(1.982 \mathrm{~g}, 1.89 \mathrm{mmol})$ was dissolved in $144 \mathrm{~mL}$ of DCM and $16 \mathrm{~mL}$ of water and cooled to $0{ }^{\circ} \mathrm{C}$. To this solution was added 2,3-dichloro-5,6-dicyano-1,4-benzoquinone (DDQ, $0.645 \mathrm{~g}, 2.84 \mathrm{mmol}$ ), and the reaction as allowed to warm to room temperature and stir overnight. The reaction was then diluted with DCM and washed with sat. $\mathrm{NaHCO}_{3}$ and water until the wash was colorless. After concentration and purification by silica gel chromatography (4:1:1 hexanes:DCM:ethyl acetate (EtOAC)), $1.695 \mathrm{~g}$ of $p$-tolyl 6-O-acetyl-2-azido-3-O-benzyl-4-O-tert-butyldimethylsilyl-2-deoxy- $\alpha$-Dglucopyranosyl-( $1 \rightarrow 4)$-2-O-benzoyl-3-O-benzyl-1-thio- $\alpha$-L-idopyranoside was isolated in $98 \%$ yield. ${ }^{1} \mathrm{H}$ NMR $\delta_{\mathrm{H}}\left(500 \mathrm{MHz}, \mathrm{CDCl}_{3}\right) 8.07$ $(2 \mathrm{H}, \mathrm{dd}, J 7.1,1.3), 7.45-7.12(14 \mathrm{H}, \mathrm{m}), 7.06(2 \mathrm{H}, \mathrm{d}, J 7.9), 7.00(2 \mathrm{H}$, d, J 7.5), $5.52(1 \mathrm{H}, \mathrm{s}, \mathrm{H}-1 \mathrm{~A}), 5.31(1 \mathrm{H}, \mathrm{d}, J 1.3, \mathrm{H}-2 \mathrm{~A}), 4.92(1 \mathrm{H}, \mathrm{d}$, $J 11.8, \mathrm{Bn}), 4.78(1 \mathrm{H}, \mathrm{t}, J 6.8, \mathrm{H}-5 \mathrm{~A}), 4.69(1 \mathrm{H}, \mathrm{d}, J 11.8, \mathrm{Bn}), 4.48(1 \mathrm{H}$, d, J 1.8, H-1B ), 4.33 (1 H, dd, J 11.8, 1.7), $4.10(1 \mathrm{H}, \mathrm{s}, \mathrm{H}-3 \mathrm{~A}), 4.08-3.99$ $(2 \mathrm{H}, \mathrm{m}), 3.91(1 \mathrm{H}, \mathrm{dd}, J 11.8,6.6), 3.88-3.78(2 \mathrm{H}, \mathrm{m}, \mathrm{H}-6 \mathrm{~A}, \mathrm{H}-4 \mathrm{~B})$, $3.74(2 \mathrm{H}, \mathrm{d}, J 11.2, \mathrm{H}-6 \mathrm{~A}), 3.62(1 \mathrm{H}, \mathrm{s}, \mathrm{H}-4 \mathrm{~A}), 3.39-3.31(1 \mathrm{H}, \mathrm{m}$, $\mathrm{H}-3 \mathrm{~B}), 3.19$ (2 H, d, J 4.8, H-2B), $2.26\left(3 \mathrm{H}, \mathrm{s}, \mathrm{S}-\mathrm{Ph}-\mathrm{CH}_{3}\right), 2.02(3 \mathrm{H}, \mathrm{s}$, Ac), $0.80\left(9 \mathrm{H}, \mathrm{s},\left(\mathrm{CH}_{3}\right)_{3} \mathrm{CSi}\right),-0.08\left(3 \mathrm{H}, \mathrm{s}, \mathrm{CH}_{3} \mathrm{Si}\right),-0.21(3 \mathrm{H}, \mathrm{s}$, $\left.\mathrm{CH}_{3} \mathrm{Si}\right) \cdot{ }^{13} \mathrm{C}$ NMR $\delta_{\mathrm{C}}\left(125 \mathrm{MHz}, \mathrm{CDCl}_{3}\right) 170.6,165.6,137.9,137.7$, $137.3,133.2,132.4,131.7,130.2,129.83,129.79,128.5,128.4,128.3$, $128.05,128.03,127.3,126.9,99.5,86.5,80.6,76.2,74.4,72.6,71.8,71.3$, $71.2,69.9,68.0,64.6,63.4,61.5,25.93,25.88,21.1,20.7,18.0,14.2,-3.8$, -4.8. HRMS $[\mathrm{M}+\mathrm{H}]^{+} \mathrm{C}_{48} \mathrm{H}_{60} \mathrm{~N}_{3} \mathrm{O}_{11} \mathrm{SSi}^{+}$calcd. 914.3712, obsd. 914.3800. $1.695 \mathrm{~g}(1.85 \mathrm{mmol})$ of $p$-tolyl 6-O-acetyl-2-azido-3-Obenzyl-4-O-tert-butyldimethylsilyl-2-deoxy- $\alpha$-D-glucopyranosyl-( $1 \rightarrow 4)$ 2-O-benzoyl-3-O-benzyl-1-thio- $\alpha$-L-idopyranoside was then protected using the general procedure for levlinoyl ester protection and purified by silica gel chromatography (2:1 hexanes:EtOAc), providing $1.747 \mathrm{~g}$ of the product 1 in $92 \%$ yield ( $88 \%$ over the two steps from compound 6 ). ${ }^{1} \mathrm{H}$ NMR $\delta_{\mathrm{H}}\left(500 \mathrm{MHz}, \mathrm{CDCl}_{3}\right) 8.13(2 \mathrm{H}, \mathrm{d}, J 7.3), 7.48(4 \mathrm{H}, \mathrm{d}, J 8.0)$, 7.45-7.20 (9 H, m), $7.13(2 \mathrm{H}, \mathrm{d}, J 7.8), 7.09(2 \mathrm{H}, \mathrm{d}, J 7.7), 5.58(1 \mathrm{H}, \mathrm{s}$, H-1A), 5.35 (1 H, s, H-2A), $4.97(1 \mathrm{H}, \mathrm{d}, J 11.7, \mathrm{Bn}), 4.95(1 \mathrm{H}, \mathrm{m}$, H-5A), 4.76 (1 H, d, J 11.7, Bn), 4.56 (1 H, d, J 3.3, H-1B), 4.45-4.39 $(1 \mathrm{H}, \mathrm{m}, \mathrm{H}-6 \mathrm{~A}), 4.35(2 \mathrm{H}, \mathrm{d}, J 11.9, \mathrm{H}-6 \mathrm{~A}, \mathrm{H}-6 \mathrm{~B}), 4.16(2 \mathrm{H}, \mathrm{d}, J 11.4, \mathrm{Bn}$, H-3A), 4.03 (1 H, dd, J 12.0, 5.3, H-6B), 3.90 (1 H, d, J 11.5, Bn), 3.84$3.80(1 \mathrm{H}, \mathrm{m}, \mathrm{H}-5 \mathrm{~B}), 3.63(1 \mathrm{H}, \mathrm{s}, \mathrm{H}-4 \mathrm{~A}), 3.48(1 \mathrm{H}, \mathrm{t}, J 8.5, \mathrm{H}-4 \mathrm{~B})$,
$3.32-3.23$ (2 H, m, H-2B, H-3B), 2.79-2.67 (2 H, m, CH $\mathrm{CH}_{2} \mathrm{Lev}$ ), 2.64$2.53\left(2 \mathrm{H}, \mathrm{m}, \mathrm{CH}_{2} \mathrm{Lev}\right), 2.33\left(3 \mathrm{H}, \mathrm{s}, \mathrm{S}-\mathrm{Ph}-\mathrm{CH}_{3}\right), 2.16(3 \mathrm{H}, \mathrm{s}), 2.04$ $(3 \mathrm{H}, \mathrm{s}), 0.86\left(9 \mathrm{H}, \mathrm{s},\left(\mathrm{CH}_{3}\right)_{3} \mathrm{CSi}\right),-0.03\left(3 \mathrm{H}, \mathrm{s}, \mathrm{CH}_{3} \mathrm{Si}\right),-0.14(3 \mathrm{H}, \mathrm{s}$, $\left.\mathrm{CH}_{3} \mathrm{Si}\right) .{ }^{13} \mathrm{C}$ NMR $\delta_{\mathrm{C}}\left(125 \mathrm{MHz}, \mathrm{CDCl}_{3}\right) 206.2,172.2,170.6,165.6$, $137.8,137.6,137.2$, 133.2, 132.0, 131.9, 130.0, 129.8, 129.7, 128.5, 128.4, $128.3,128.1,128.0,127.2,126.9,99.2,86.3,80.6,75.9,74.4,72.6,71.6$, 71.2, 71.0, 69.7, 66.2, 64.6, 63.8, 63.0, 60.3, 37.8, 29.8, 27.8, 25.9, 21.1, 21.0, 20.8, 18.0, 14.2, -3.8, -4.9. HRMS $[\mathrm{M}+\mathrm{H}]^{+} \mathrm{C}_{53} \mathrm{H}_{66} \mathrm{~N}_{3} \mathrm{O}_{13} \mathrm{SSi}^{+}$ calcd. 1012.4080, obsd. 1012.4083.

p-Tolyl 6-O-Acetyl-2-azido-3-O-benzyl-2-deoxy- $\alpha$-D-glucopyranosyl-(1 $\rightarrow 4)-2-0$-benzoyl-3-O-benzyl-6-levulinoyl-1-thio- $\alpha-L$ idopyranoside (2). Compound $2(0.300 \mathrm{~g}, 0.33 \mathrm{mmol})$ was prepared from 1 by following the general procedure for TBS removal and subsequent purification by silica gel chromatography (2:1 hexanes:EtOAc then 1:1 hexanes:EtOAc), providing $0.260 \mathrm{~g}$ of 2 in $98 \%$ yield. ${ }^{1} \mathrm{H}$ NMR $\delta_{\mathrm{H}}\left(500 \mathrm{MHz}, \mathrm{CDCl}_{3}\right) 8.20-8.17(2 \mathrm{H}, \mathrm{m}), 7.53-7.25(13 \mathrm{H}$, m), $7.19(2 \mathrm{H}, \mathrm{dd}, J 9.1,2.6), 7.15(2 \mathrm{H}, \mathrm{d}, J 8.1), 5.60(1 \mathrm{H}, \mathrm{s}, \mathrm{H}-1 \mathrm{~A})$, $5.41(1 \mathrm{H}, \mathrm{s}, \mathrm{H}-2 \mathrm{~A}), 5.02-4.97(2 \mathrm{H}, \mathrm{m}, \mathrm{Bn}, \mathrm{H}-5), 4.78(1 \mathrm{H}, \mathrm{d}, J$ 11.7, $\mathrm{Bn}), 4.60(1 \mathrm{H}, \mathrm{d}, J 3.8, \mathrm{H}-1 \mathrm{~B}), 4.50(1 \mathrm{H}, \mathrm{dd}, J 12.4,4.4, \mathrm{H}-6 \mathrm{~B}), 4.42$ $(1 \mathrm{H}, \mathrm{dd}, J$ 11.6, 8.0, H-6A), $4.37(1 \mathrm{H}, \mathrm{d}, J 10.6, \mathrm{Bn}), 4.34(1 \mathrm{H}, \mathrm{dd}$, $J$ 11.6, 4.4, H-6A), 4.22 (1 H, dt, J 6.0, 3.0, H-6B), 4.19 (1 H, t, J 2.4, H-3A), 4.07 (1 H, d, J 10.6, Bn), 3.86 (1 H, ddd, J 10.0, 4.2, 2.0, H-5B), $3.67(1 \mathrm{H}, \mathrm{t}, J 2.3, \mathrm{H}-4 \mathrm{~A}), 3.47(1 \mathrm{H}, \mathrm{dd}, J 10.1,9.0, \mathrm{H}-3 \mathrm{~B}), 3.35(1 \mathrm{H}, \mathrm{t}, J$ 9.5, H-4B), 3.24 (1 H, dd, J 10.1, 3.8, H-2B), $3.02(1 \mathrm{H}, \mathrm{br}, \mathrm{OH}), 2.75$ $\left(2 \mathrm{H}, \mathrm{t}, J 6.6, \mathrm{CH}_{2} \mathrm{Lev}\right), 2.60\left(2 \mathrm{H}, \mathrm{t}, J 6.6, \mathrm{CH}_{2} \mathrm{Lev}\right), 2.36$ (3 H, s, S-Ph$\left.\mathrm{CH}_{3}\right), 2.17\left(3 \mathrm{H}, \mathrm{s}, \mathrm{CH}_{3}, \mathrm{Lev}\right), 2.08(3 \mathrm{H}, \mathrm{s}, \mathrm{Ac}) .{ }^{13} \mathrm{C} \mathrm{NMR} \delta_{\mathrm{C}}(125 \mathrm{MHz}$,

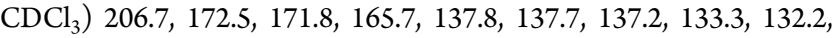
$131.8,129.94,129.86,129.7,128.6,128.48,128.46,128.33,128.26$, $128.12,128.10,127.9,98.9,86.4,80.1,75.3,75.1,72.6,71.3,71.2,70.5$, $69.5,66.1,63.8,63.3,63.0,37.9,29.8,27.8,21.2,20.8,14.2$. HRMS $[\mathrm{M}+\mathrm{Na}]^{+} \mathrm{C}_{47} \mathrm{H}_{51} \mathrm{~N}_{3} \mathrm{NaO}_{13} \mathrm{~S}^{+}$calcd. 920.3040, obsd. 920.3034 .

$\mathrm{N}$-(Benzyl)-benzyloxycarbonyl-3-aminopropyl 6-O-Acetyl-2azido-3-O-benzyl-2-deoxy- $\alpha$-D-glucopyranosyl- $(1 \rightarrow 4)-2-0$-benzoyl3-O-benzyl-6-levulinoyl- $\alpha$-L-idopyranoside (3). Compound 3 was prepared from $8(549 \mathrm{mg}, 0.46 \mathrm{mmol})$ using the general procedure for TBS removal, followed by silica gel chromatography (1:1 hexanes:EtOAc) to yield $95 \%$ of compound $3(470 \mathrm{mg}) .{ }^{1} \mathrm{H}$ NMR $\delta_{\mathrm{H}}$ $\left(500 \mathrm{MHz}, \mathrm{CDCl}_{3}\right) 8.17(2 \mathrm{H}, \mathrm{d}, J 7.1), 7.51(1 \mathrm{H}, \mathrm{t}, J 7.3), 7.45(2 \mathrm{H}, \mathrm{t}$, J 7.5), 7.41-7.14 (20 H, m), 5.22-5.12 (3 H, m, H-2A, $\left.\mathrm{CH}_{2}-\mathrm{CBz}\right), 4.96$ $(1 \mathrm{H}, \mathrm{d}, \mathrm{H}-1 \mathrm{~A}), 4.85(1 \mathrm{H}, \mathrm{t}, J$ J 10.6, Bn $), 4.77-4.72(1 \mathrm{H}, \mathrm{m}, \mathrm{Bn}), 4.71$ (1 H, d, J 3.5, H-1B), 4.56-4.45 (4 H, m, H-6A, H-6B, 2Bn), 4.444,37 ( $2 \mathrm{H}, \mathrm{d}, J$ 9.5, H-5A, Bn), 4.32-4.22 (3 H, m, H-6B, H-6A, Bn), 4.10 ( $1 \mathrm{H}, \mathrm{s}, J$ 10.4, H-3A), 3.86 (1 H, s, H-5B), 3.79 (1 H, s, H-linker), 3.71 (1 H, s, H-4A), 3.59 (1 H, t, J 9.5, H-3B), 3.56-3.32 (4 H, m, H-4B, H-linker, $\mathrm{CH}_{2}$-linker), $3.24(1 \mathrm{H}, \mathrm{dd}, J$ 10.1, 3.5, H-2B), $2.73(2 \mathrm{H}, \mathrm{s}$, $\mathrm{CH}_{2}$ Lev), 2.58 ( $2 \mathrm{H}, \mathrm{d}, J$ 13.9, $\mathrm{CH}_{2}$ Lev $), 2.17$ ( $\left.3 \mathrm{H}, \mathrm{s}, \mathrm{CH}_{3} \mathrm{Lev}\right), 2.07$ $(3 \mathrm{H}, \mathrm{s}, \mathrm{Ac}), 1.89\left(2 \mathrm{H}, \mathrm{d}, J 23.2, \mathrm{CH}_{2}\right.$-linker). ${ }^{13} \mathrm{C}$ NMR $\delta_{\mathrm{C}}(125 \mathrm{MHz}$,

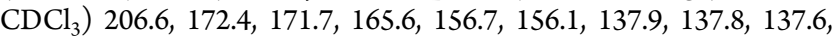
$136.7,133.3,129.9,129.8,128.61,128.56,128.53,128.45,128.3,128.2$, $128.1,128.0,127.92,127.86,127.78,127.5,127.3,98.4,98.3,80.0,75.1$, $74.5,72.4,72.3,71.2,70.7,68.8,67.2,65.6,63.6,63.2,63.0,60.4,51.0$, $50.8,44.9,43.9,37.8,30.9,29.8,28.4,27.8,21.0,20.8,14.2 .{ }^{1} J_{\mathrm{C} 1 \mathrm{BH} 1 \mathrm{~B}}=$ $171.5 \mathrm{~Hz},{ }^{1} J_{\mathrm{C} 1 \mathrm{AH} 1 \mathrm{~A}}=170 \mathrm{~Hz}$. HRMS $[\mathrm{M}+\mathrm{H}]^{+} \mathrm{C}_{58} \mathrm{H}_{65} \mathrm{~N}_{4} \mathrm{O}_{16}{ }^{+}$calcd. 1073.4390, obsd. 1073.4394.

p-Tolyl 6-O-Acetyl-2-azido-3-O-benzyl-4-O-tert-butyldimethylsilyl-2-deoxy-1-thio- $\beta$-D-glucopyranoside (4). Compound 4 was prepared as previously described. ${ }^{17}{ }^{1} \mathrm{H}$ NMR $\delta_{\mathrm{H}}\left(500 \mathrm{MHz}, \mathrm{CDCl}_{3}\right)$ $7.50(2 \mathrm{H}, \mathrm{m}), 7.36(4 \mathrm{H}, \mathrm{m}), 7.30(1 \mathrm{H}, \mathrm{m}), 7.15(2 \mathrm{H}, \mathrm{m}), 4.91(1 \mathrm{H}, \mathrm{d}$, $J 11.0, \mathrm{Bn}), 4.79(1 \mathrm{H}, \mathrm{d}, J 11.0, \mathrm{Bn}), 4.50(1 \mathrm{H}, \mathrm{dd}, J 11.8,2.3, \mathrm{H}-6), 4.42$ $(1 \mathrm{H}, \mathrm{m}, J$ 9.9, H-1), 4.08 (1 H, dd, J 11.8, 5.6, H-6), $3.57(1 \mathrm{H}, \mathrm{m}, \mathrm{H}-4)$, 3.46 ( $1 \mathrm{H}$, ddd, $J$ 9.4, 5.6, 2.3, H-5), $3.32(2 \mathrm{H}, \mathrm{m}, \mathrm{H}-2, \mathrm{H}-3), 2.38(3 \mathrm{H}, \mathrm{s}$, $\left.\mathrm{SPhCH}_{3}\right), 2.11(3 \mathrm{H}, \mathrm{s}, \mathrm{Ac}), 0.92\left(9 \mathrm{H}, \mathrm{s}, J 7.8,\left(\mathrm{CH}_{3}\right)_{3} \mathrm{CSi}\right), 0.05(3 \mathrm{H}, \mathrm{s}$, $\left.\mathrm{CH}_{3} \mathrm{Si}\right), 0.04\left(3 \mathrm{H}, \mathrm{s}, \mathrm{CH}_{3} \mathrm{Si}\right) .{ }^{13} \mathrm{C}$ NMR $\left(125 \mathrm{MHz}, \mathrm{CDCl}_{3}\right): 170.8$, 138.9, 138.1, 134.3, 130.0, 128.6, 128.0, 127.8, 127.5, 86.6, 85.4, 78.7, $76.0,70.7,65.7,63.3,26.1,21.5,21.2,18.2,-3.4,-4.6$. HRMS $[\mathrm{M}+\mathrm{H}]^{+}$ $\mathrm{C}_{28} \mathrm{H}_{40} \mathrm{~N}_{3} \mathrm{O}_{5} \mathrm{SSi}^{+}$calcd. 558.2452, obsd. 558.2461.

p-Tolyl 2-O-Benzoyl-3-O-benzyl-6-O-p-methoxybenzyl-1-thio- $\alpha$ L-idopyranoside (5). Compound 5 was prepared as previously described. ${ }^{17}{ }^{1} \mathrm{H}$ NMR $\delta_{\mathrm{H}}\left(500 \mathrm{MHz}, \mathrm{CDCl}_{3}\right) 8.02(2 \mathrm{H}, \mathrm{m}), 7.59$ $(1 \mathrm{H}, \mathrm{m}), 7.39(11 \mathrm{H}, \mathrm{m}), 7.06(2 \mathrm{H}, \mathrm{m}), 6.91(2 \mathrm{H}, \mathrm{m}), 5.56(1 \mathrm{H}, \mathrm{s}, \mathrm{H}-1)$, 
$5.52(1 \mathrm{H}, \mathrm{dt}, J 2.4,1.0, \mathrm{H}-2), 5.00(1 \mathrm{H}, \mathrm{t}, J 4.9, \mathrm{H}-5), 4.93$ (1 H, d, J 11.8, $\mathrm{Bn}), 4.69(1 \mathrm{H}, \mathrm{d}, J 11.9, \mathrm{Bn}), 4.56(2 \mathrm{H}, \mathrm{q}, J 11.5, \mathrm{Bn}), 3.90(1 \mathrm{H}, \mathrm{td}$, $J 2.9,1.3, \mathrm{H}-3), 3.83\left(6 \mathrm{H}, \mathrm{m}, \mathrm{H}-4, \mathrm{H}-6, \mathrm{OCH}_{3}\right), 2.85(1 \mathrm{H}, \mathrm{d}, J 9.7, \mathrm{OH})$, $2.33\left(3 \mathrm{H}, \mathrm{s}, \mathrm{SPhCH}_{3}\right) .{ }^{13} \mathrm{C} \mathrm{NMR}\left(125 \mathrm{MHz}, \mathrm{CDCl}_{3}\right): \delta 164.9,159.1$, $137.5,137.3,133.4,132.4,131.9,130.0,129.6,113.6,129.5,129.2,129.1$, 128.4, 128.3, 127.8, 127.6, 86.9, 74.0, 73.0, 72.1, 69.9, 69.7, 67.9, 67.1, 60.2, 55.1, 21.0,14.0. HRMS $[\mathrm{M}+\mathrm{H}]^{+} \mathrm{C}_{35} \mathrm{H}_{37} \mathrm{O}_{7} \mathrm{~S}^{+}$calcd. 601.2255, obsd. 601.2260 .

p-Tolyl 6-O-Acetyl-2-azido-3-O-benzyl-4-O-tert-butyldimethylsilyl-2-deoxy- $\alpha$-D-glucopyranosyl-(1 $\rightarrow 4)-2-0$-benzoyl-3-O-benzyl-60 -p-methoxybenzyl-1-thio- $\alpha$-L-idopyranoside (6). Compound 6 was synthesized from donor $4(0.45 \mathrm{~g}, 0.81 \mathrm{mmol})$ and $5(0.533 \mathrm{~g}$, $0.9 \mathrm{mmol})$ in $85 \%$ yield $(0.719 \mathrm{~g}$ of 6$)$ following the general procedure of a single-step glycosylation with one alteration. The reaction solvent used contained more than $50 \% \mathrm{Et}_{2} \mathrm{O}$ at all times. The lower fraction of $\mathrm{Et}_{2} \mathrm{O}$ led to the activation of product and the formation of a 1,6-anhydro glycan. ${ }^{17,49}$ Purification was performed by silica gel chromatography (6:1:1 hexanes:DCM:EtOAc). ${ }^{1} \mathrm{H}$ NMR $\left(500 \mathrm{MHz}, \mathrm{CDCl}_{3}\right) \delta_{\mathrm{H}} 8.14$ $(2 \mathrm{H}, \mathrm{dd}, J$ J 8.4 1.3), 7.52-7.22 (15 H, m), 7.15 (2 H, d, J 6.9), 7.07-7.03 $(2 \mathrm{H}, \mathrm{m}), 6.93-6.89(2 \mathrm{H}, \mathrm{m}), 5.58(1 \mathrm{H}, \mathrm{s}, \mathrm{H}-1 \mathrm{~A}), 5.38(1 \mathrm{H}, \mathrm{t}, J$ 2.1, H-2A), 5.00-4.94 (2 H, m, H-5A, Bn), $4.76(1 \mathrm{H}, \mathrm{d}, J 11.7, \mathrm{Bn}), 4.69(1 \mathrm{H}$, d, J 3.7, H-1B), 4.57-4.49 (2 H, m, Bn), 4.31-4.22 (2 H, m, H-6B, Bn), $4.18(1 \mathrm{H}, \mathrm{t}, J 3.2, \mathrm{H}-3 \mathrm{~A}), 4.08(1 \mathrm{H}, \mathrm{d}, J 11.3, \mathrm{Bn}), 4.06-4.02(1 \mathrm{H}, \mathrm{m}$, H-6B), 3.87-3.80 (5 H, m, PhOCH $\left.{ }_{3}, \mathrm{H}-5 \mathrm{~B}, \mathrm{H}-6 \mathrm{~A}\right) 3.77$ (1 H, dd, J 10.2, 5.0, H-6A), $3.71(1 \mathrm{H}, \mathrm{s}, \mathrm{H}-4 \mathrm{~A}), 3.55(1 \mathrm{H}, \mathrm{t}, J$ 9.1, H-4B $), 3.40-3.35$ $(1 \mathrm{H}, \mathrm{m}, \mathrm{H}-3 \mathrm{~B}), 3.29$ (1 H, dd, J 10.2, 3.7, H-2B), 2.33 (3 H, s, S-Ph$\left.\mathrm{CH}_{3}\right), 2.06(3 \mathrm{H}, \mathrm{s}, \mathrm{Ac}), 0.90\left(9 \mathrm{H}, \mathrm{s},\left(\mathrm{CH}_{3}\right)_{3} \mathrm{CSi}\right),-0.00\left(3 \mathrm{H}, \mathrm{s} \mathrm{CH} \mathrm{CH}_{3}\right)$, $-0.10\left(3 \mathrm{H}, \mathrm{s}, \mathrm{CH}_{3} \mathrm{Si}\right) .{ }^{13} \mathrm{C} \mathrm{NMR}\left(125 \mathrm{MHz}, \mathrm{CDCl}_{3}\right) \delta_{\mathrm{C}} 170.8,165.9$, 159.5, 138.0, 137.8, 137.6, 133.4, 132.7, 132.0, 130.4, 130.2, 130.1, 129.8, $129.5,128.7,128.6,128.4,128.3,128.2,127.5,127.3,114.0,98.7,86.7$, 80.8, 75.2, 74.8, 73.2, 72.9, 72.2, 71.6, 71.2, 70.4, 69.4, 67.6, 64.9, 63.2, 55.5, 26.2, 21.4, 21.1, 18.2, -3.5, -4.7. gHSQCAD (without ${ }^{1} \mathrm{H}$ decoupling ${ }^{1} J_{\mathrm{C} 1 \mathrm{BH} 1 \mathrm{~B}}=171 \mathrm{~Hz},{ }^{1} J_{\mathrm{C} 1 \mathrm{AH} 1 \mathrm{~A}}=167.5 \mathrm{~Hz}$; HRMS $[\mathrm{M}+\mathrm{Li}]^{+}$ $\mathrm{C}_{56} \mathrm{H}_{6} \mathrm{LiN}_{3} \mathrm{O}_{12} \mathrm{SSi}^{+}$calcd. 1040.4369, obsd. 1040.4373.

$\mathrm{N}$-(Benzyl)-benzyloxycarbonyl-3-aminopropyl 6-O-Acetyl-2azido-3-O-benzyl-4-O-tert-butyldimethylsilyl-2-deoxy- $\alpha$-D-glucopyranosyl-(1 $\rightarrow 4)-2-0$-benzoyl-3-O-benzyl-6-levulinoyl- $\alpha$-L-idopyranoside (8). Compound $\mathbf{8}$ was prepared by glycosylation of donor $\mathbf{1}$ (307 mg, $0.3 \mathrm{mmol})$ with $7^{25}(118 \mathrm{mg}, 0.394 \mathrm{mmol})$ in $81 \%$ yield following the procedure for glycosylation. Purification was performed by silica gel chromatography ( 2 fractions 2:1 hexanes:EtOAC, then 1:1 hexanes:EtOAC), providing $290 \mathrm{mg}$ of $8 .{ }^{1} \mathrm{H}$ NMR $\delta_{\mathrm{H}}(500 \mathrm{MHz}$, $\left.\mathrm{CDCl}_{3}\right) 8.14(2 \mathrm{H}, \mathrm{d}, J$ 7.2), 7.52-7.08 $(23 \mathrm{H}, \mathrm{m}), 5.17(2 \mathrm{H}, \mathrm{d}, J$ 8 8.5 , $\left.\mathrm{CH}_{2}-\mathrm{Cbz}\right), 5.11(1 \mathrm{H}, \mathrm{s}, \mathrm{H}-2 \mathrm{~A}), 4.99(0.5 \mathrm{H}$ due to restricted rotation around $\mathrm{N}, \mathrm{bs}, \mathrm{H}-1 \mathrm{~A}), 4.94(0.5 \mathrm{H}$ due to restricted rotation around $\mathrm{N}$, bs, H-1A), 4.87 (0.5 H, d, J 11.4, Bn), 4.83 (0.5 H, d, J 11.4, Bn), 4.74 $(1 \mathrm{H}, \mathrm{d}, J 11.4, \mathrm{Bn}), 4.67(1 \mathrm{H}, \mathrm{d}, J 3.5, \mathrm{H}-1 \mathrm{~B}), 4.56-4.40(4 \mathrm{H}, \mathrm{m}, \mathrm{H}-5 \mathrm{~A}$, $\left.\mathrm{H}-6 \mathrm{~A}, \mathrm{CH}_{2}-\mathrm{Bn}\right), 4.40-4.34(2 \mathrm{H}, \mathrm{m}, \mathrm{H}-6 \mathrm{~B}, \mathrm{Bn}), 4.30(1 \mathrm{H}, \mathrm{s}, \mathrm{H}-6 \mathrm{~A})$, $4.14(1 \mathrm{H}, \mathrm{d}, J$ 9.0, Bn $), 4.11-4.04(2 \mathrm{H}, \mathrm{m}, \mathrm{H}-3 \mathrm{~A}, \mathrm{H}-6 \mathrm{~B}), 3.89-3.75$ (2 H, m, H-5B, H-linker), 3.68 ( $1 \mathrm{H}, \mathrm{s}, \mathrm{H}-4 \mathrm{~A}), 3.57-3.46$ (2 H, m, H-4B, H-linker), 3.45-3.32 ( $3 \mathrm{H}, \mathrm{m}, J$ 10.1, $\mathrm{H}-3 \mathrm{~B}, \mathrm{CH}_{2}$-linker), 3.27 ( $1 \mathrm{H}, \mathrm{dd}$, $J$ 10.1, 3.5, H-2B), $2.74\left(2 \mathrm{H}, \mathrm{s}, \mathrm{CH}_{2} \mathrm{Lev}\right), 2.60\left(2 \mathrm{H}, \mathrm{d}, J 16.9, \mathrm{CH}_{2} \mathrm{Lev}\right)$, $2.17\left(3 \mathrm{H}, \mathrm{s}, \mathrm{CH}_{3} \mathrm{Lev}\right), 2.06(3 \mathrm{H}, \mathrm{s}, \mathrm{Ac}), 1.89\left(2 \mathrm{H}, \mathrm{d}, J 21.0, \mathrm{CH}_{2}-\right.$ linker), $0.90\left(9 \mathrm{H}, \mathrm{s},\left(\mathrm{CH}_{3}\right)_{3} \mathrm{CSi}\right), 0.01\left(1 \mathrm{H}, \mathrm{s}, \mathrm{CH}_{3} \mathrm{Si}\right),-0.08(2 \mathrm{H}, \mathrm{s}$, $\left.\mathrm{CH}_{3} \mathrm{Si}\right) .{ }^{13} \mathrm{C}$ NMR $\delta_{\mathrm{C}}\left(125 \mathrm{MHz}, \mathrm{CDCl}_{3}\right) 206.2,172.3,170.6,165.6$, 156.6, 156.1, 138.0, 137.8, 137.6, 133.2, 130.0, 129.8, 128.51, 128.48, $128.3,128.09,128.06,127.90,127.85,127.78,127.3,127.0,98.6,98.3$, $80.5,75.0,74.6,72.5,72.3,71.5,71.1,68.9,67.1,65.7,64.5,63.6,63.0$, 60.4, 50. 8, 44.9, 43.9, 37.8, 29.8, 28.4, 27.8, 25.9, 21.0, 20.8, 18.0, 14.2, $-3.8,-4.9$. HRMS $[\mathrm{M}+\mathrm{H}]^{+} \mathrm{C}_{64} \mathrm{H}_{79} \mathrm{~N}_{4} \mathrm{O}_{16} \mathrm{Si}^{+}$calcd. 1187.5255, obsd. 1187.5254

p-Tolyl 6-O-Acetyl-2-azido-3-O-benzyl-4-O-tert-butyldimethylsilyl-2-deoxy- $\alpha$-D-glucopyranosyl-(1 $\rightarrow 4)-2-0$-benzoyl-3-O-benzyl-6levulinoyl- $\alpha$-L-idopyranoside-(1 $\rightarrow 4)-6-0$-acetyl-2-azido-3-O-benzyl2-deoxy- $\alpha$-D-glucopyranosyl-(1 $\rightarrow 4)$-2-O-benzoyl-3-O-benzyl-6-levulinoyl-1-thio- $\alpha$-L-idopyranoside (9). Compound 9 was synthesized according to the general procedure of glycosylation with donor $\mathbf{1}$ (200 mg, $197 \mu \mathrm{mol}$ ) and acceptor $2(177 \mathrm{mg}, 197 \mu \mathrm{mol})$ in $81 \%$ yield and purified by silica gel chromatography (1:1 hexanes:EtOAc), providing $285 \mathrm{mg}$ of $9 .{ }^{1} \mathrm{H}$ NMR $\delta_{\mathrm{H}}\left(500 \mathrm{MHz}, \mathrm{CDCl}_{3}\right) 8.31-8.26$ $(2 \mathrm{H}, \mathrm{m}), 8.22(2 \mathrm{H}, \mathrm{t}, J 9.0), 7.66-7.25(30 \mathrm{H}, \mathrm{m}), 5.70(1 \mathrm{H}, \mathrm{s}, \mathrm{H}-1 \mathrm{~A})$,
$5.51(1 \mathrm{H}, \mathrm{s}, \mathrm{H}-2 \mathrm{~A}), 5.28(1 \mathrm{H}, \mathrm{t}, J 4.1, \mathrm{H}-2 \mathrm{C}), 5.21(1 \mathrm{H}, \mathrm{d}, J 3.0, \mathrm{H}-1 \mathrm{C})$, $5.10(1 \mathrm{H}, \mathrm{d}, J 11.7, \mathrm{Bn}), 5.08-5.02(1 \mathrm{H}, \mathrm{m}, \mathrm{H}-5 \mathrm{~A}), 4.95(1 \mathrm{H}, \mathrm{d}, J 2.4$, H-1D), $4.91(3 \mathrm{H}, \mathrm{t}, J 11.0,3 \mathrm{Bn}), 4.69(1 \mathrm{H}, \mathrm{d}, J 3.4, \mathrm{H}-1 \mathrm{~B}), 4.65(2 \mathrm{H}, \mathrm{t}$, J 9.9, Bn ), 4.58-4.51 (2 H, m, Bn), 4.50-4.42 (4 H, m, H-6A), 4.42-4.34 (2 H, m, H-6A, H-6D), 4.30-4.27 (1 H, m, H-3A), 4.26-4.16 (3 H, m, H-3C, H-6D), 3.98 (1 H, d, J 8.9, H-5B), 3.88 (3 H, d, J 10.3, Bn, H-5D), $3.81(1 \mathrm{H}, \mathrm{t}, J$ 9.4, H-4B), $3.75(1 \mathrm{H}, \mathrm{s}, \mathrm{H}-4 \mathrm{~A}), 3.71(1 \mathrm{H}, \mathrm{t}$, J 9.0, H-4D), $3.62(2 \mathrm{H}, \mathrm{dt}, J$ 12.2, 9.5, H-3B, H-3D), 3.39 (2 H, td, J 9.8, 2.8, H-2B, H-2D), 2.90-2.60 ( $\left.8 \mathrm{H}, \mathrm{m}, 4-\mathrm{CH}_{2} \mathrm{Lev}\right), 2.48$ ( $\left.3 \mathrm{H}, \mathrm{s}, \mathrm{S}-\mathrm{Ph}-\mathrm{CH}_{3}\right), 2.28$ $\left(3 \mathrm{H}, \mathrm{s}, \mathrm{CH}_{3} \mathrm{Lev}\right), 2.26\left(3 \mathrm{H}, \mathrm{s}, \mathrm{CH}_{3} \mathrm{Lev}\right), 2.16(3 \mathrm{H}, \mathrm{s}, \mathrm{Ac}), 2.14(3 \mathrm{H}, \mathrm{s}$, $\mathrm{Ac}), 1.03\left(9 \mathrm{H}, \mathrm{s},\left(\mathrm{CH}_{3}\right)_{3} \mathrm{CSi}\right), 0.15\left(3 \mathrm{H}, \mathrm{s}, \mathrm{CH}_{3} \mathrm{Si}\right), 0.08(3 \mathrm{H}, \mathrm{s}$, $\left.\mathrm{CH}_{3} \mathrm{Si}\right) .{ }^{13} \mathrm{C}$ NMR $\delta_{\mathrm{C}}\left(125 \mathrm{MHz}, \mathrm{CDCl}_{3}\right) 206.2,172.17,172.16,170.64$, $170.58,165.7,165.4,137.8,137.7,137.32,137.26,133.4,133.3,132.2$, $131.9,129.9,129.8,129.7,129.6,128.7,128.6,128.45,128.40,128.29$, $128.26,128.15,128.10,128.05,128.01,127.98,127.5,127.4,127.1,98.9$, 98.6, 97.7, 86.4, 80.3, 79.0, 75.8, 75.5, 74.8, 74.7, 74.6, 73.6, 72.6, 71.5, $71.4,71.1,70.8,70.3,69.6,68.2,66.0,64.2,63.9,63.5,62.8,62.4,62.0$, $37.9,37.8,29.78,29.77,27.8,25.9,21.1,20.74,20.71,18.0,-3.7,-4.9$. ${ }^{1} J_{\mathrm{C} 1 \mathrm{AH} 1 \mathrm{~A}}=168 \mathrm{~Hz},{ }^{1} J_{\mathrm{C} 1 \mathrm{BH} 1 \mathrm{~B}}=171.5 \mathrm{~Hz},{ }^{1} J_{\mathrm{C} 1 \mathrm{CH} 1 \mathrm{C}}=169.5 \mathrm{~Hz},{ }^{1} J_{\mathrm{C} 1 \mathrm{DH} 1 \mathrm{D}}=$ $173 \mathrm{~Hz}$. HRMS $[\mathrm{M}+\mathrm{H}]^{+} \mathrm{C}_{93} \mathrm{H}_{109} \mathrm{~N}_{6} \mathrm{O}_{26} \mathrm{SSi}^{+}$calcd. 1785.6876, obsd. 1785.6873.

$\mathrm{N}$-(Benzyl)-benzyloxycarbonyl-3-aminopropyl 6-O-Acetyl-2azido-3-O-benzyl-4-O-tert-butyldimethylsilyl-2-deoxy- $\alpha$-D-glucopyranosyl- $(1 \rightarrow 4)-2-0$-benzoyl-3-O-benzyl-6-levulinoyl- $\alpha-L$ idopyranoside-(1 $\rightarrow 4)-6-O$-acetyl-2-azido-3-O-benzyl-2-deoxy- $\alpha$ - $D$ glucopyranosyl-(1 $\rightarrow 4$ )-2-O-benzoyl-3-O-benzyl-6-levulinoyl-1-thio$\alpha$-L-idopyranoside- $(1 \rightarrow 4)$-6-O-acetyl-2-azido-3-O-benzyl-2-deoxy$\alpha$-D-glucopyranosyl-(1 $\rightarrow 4)-2-0$-benzoyl-3-O-benzyl-6-levulinoyl- $\alpha$ L-idopyranoside (10). Compound 10 was synthesized in $61 \%$ yield from donor 9 (346 mg, $190 \mu \mathrm{mol})$ and acceptor $3(208 \mathrm{mg}, 190 \mu \mathrm{mol})$ following the general procedure for glycosylation and was purified by silica gel flash chromatography (1:1:1 hexanes:DCM:EtOAc), providing $384 \mathrm{mg}$ of 10 (72\% yield). ${ }^{1} \mathrm{H}$ NMR $\delta_{\mathrm{H}}\left(600 \mathrm{MHz}, \mathrm{CDCl}_{3}\right) 8.09(2 \mathrm{H}, \mathrm{d}$, $J$ 7.1), $8.06(4 \mathrm{H}$, ddd, J 8.5, 2.2, 1.3), 7.50-7.07 $(49 \mathrm{H}, \mathrm{m}), 5.15-5.09$ $(4 \mathrm{H}, \mathrm{m}), 5.06(1 \mathrm{H}, \mathrm{d}, J 3.9), 5.03(1 \mathrm{H}, \mathrm{s}), 5.02(1 \mathrm{H}, \mathrm{d}, J 4.0), 4.88(1 \mathrm{H}$, m), 4.81-4.70 (8 H, m), $4.68(1 \mathrm{H}, \mathrm{s}), 4.58(2 \mathrm{H}, \mathrm{dd}, J 12.9,7.0), 4.49-$ $4.39(3 \mathrm{H}, \mathrm{m}), 4.39-4.27$ (9 H, m), 4.26-4.22 (2 H, m), 4.20-4.12 $(4 \mathrm{H}, \mathrm{m}), 4.08-3.96(6 \mathrm{H}, \mathrm{m}), 3.90(1 \mathrm{H}, \mathrm{d}, J 10.2), 3.81-3.76(1 \mathrm{H}, \mathrm{m})$, 3.75-3.67 (5 H, m), 3.67-3.63 (2 H, m), 3.62-3.56 (2 H, m), 3.52 $(2 \mathrm{H}, \mathrm{dd}, J 18.7,9.6), 3.44(1 \mathrm{H}, \mathrm{dd}, J 10.0,8.6), 3.41-3.26(2 \mathrm{H}, \mathrm{m})$, 3.24-3.19 (3 H, m), 2.69-2.34 (12 H, m, 4-CH $\left.\mathrm{CH}_{2} \mathrm{Lev}\right), 2.10\left(3 \mathrm{H}, \mathrm{s}, \mathrm{CH}_{3}\right.$ Lev), 2.09 ( $3 \mathrm{H}, \mathrm{s}, \mathrm{CH}_{3} \mathrm{Lev}$ ), 2.07 ( $\left.3 \mathrm{H}, \mathrm{s}, \mathrm{CH}_{3} \mathrm{Lev}\right), 1.98$ (3 H, s, Ac), $1.97(3 \mathrm{H}, \mathrm{s}, \mathrm{Ac}), 1.97(3 \mathrm{H}, \mathrm{s}, \mathrm{Ac}), 1.88-1.76(2 \mathrm{H}, \mathrm{m}), 0.86(9 \mathrm{H}, \mathrm{s}$, $\left.\left(\mathrm{CH}_{3}\right)_{3} \mathrm{CSi}\right),-0.03\left(3 \mathrm{H}, \mathrm{s}, \mathrm{CH}_{3} \mathrm{Si}\right),-0.10\left(3 \mathrm{H}, \mathrm{s}, \mathrm{CH}_{3} \mathrm{Si}\right) .{ }^{13} \mathrm{C} \mathrm{NMR} \delta_{\mathrm{C}}$ $\left(125 \mathrm{MHz} \mathrm{CDCl}_{3}\right) 206.5,172.5,172.43,172.39,170.9,170.8,165.9$, $165.67,165.65,138.1,138.0,137.9,137.6,137.5,133.6,130.07,130.04$, $129.78,129.75,128.87,128.84,128.75,128.63,128.59,128.55,128.39$, $128.36,128.34,128.29,128.25,128.15,128.1,127.9,127.8,127.6,127.5$, $127.3,98.8,98.6,98.1,98.0,80.6,79.2,79.0,75.6,75.2,75.1,75.0,74.8$, $74.5,73.7,72.5,71.7,71.3,70.7,70.4,68.9,68.2,67.4,65.6,64.5,64.0$, 63.9, 63.6, 63.1, 62.4, 62.2, 38.02, 37.99, 30.03, 30.01, 28.04, 28.00, 26.2, $21.3,21.0,18.3,14.5,-3.5,-4.7 .{ }^{1} J_{\mathrm{C} 1 \mathrm{AH} 1 \mathrm{~A}}=170.4 \mathrm{~Hz},{ }^{1} J_{\mathrm{C} 1 \mathrm{BH} 1 \mathrm{~B}}=169.2$ $\mathrm{Hz},{ }^{1} J_{\mathrm{C} 1 \mathrm{CH} 1 \mathrm{C}}=168.4 \mathrm{~Hz},{ }^{1} J_{\mathrm{C} 1 \mathrm{DH} 1 \mathrm{D}}=171.6 \mathrm{~Hz},{ }^{1} J_{\mathrm{C} 1 \mathrm{EH} I \mathrm{E}}=172.8 \mathrm{~Hz}$, ${ }^{1} J_{\mathrm{ClFH} 1 \mathrm{~F}}=168.6 \mathrm{~Hz}$. HRMS $[\mathrm{M}+\mathrm{H}]^{+} \mathrm{C}_{144} \mathrm{H}_{165} \mathrm{~N}_{10} \mathrm{O}_{42} \mathrm{Si}^{+}$calcd. 2735.0880, obsd. 2735.0883.

Procedure for One-Pot Synthesis of Hexasaccharide 10. A solution of donor $1(60 \mu \mathrm{mol})$ and freshly activated $4 \AA$ molecular sieves (200 mg) in $\mathrm{CH}_{2} \mathrm{Cl}_{2}(1.5 \mathrm{~mL})$ was stirred at room temperature for $10 \mathrm{~min}$, and cooled to $-78^{\circ} \mathrm{C}$, which was followed by addition of AgOTf (47 mg, $180 \mu \mathrm{mol}$ ) dissolved in $\mathrm{MeCN}(47 \mu \mathrm{L})$ without touching the wall of the flask. After $20 \mathrm{~min}$, orange-colored $p$-TolSCl $(9.5 \mu \mathrm{L}$, $60 \mu \mathrm{mol}$ ) was added to the solution through a microsyringe. Since the reaction temperature was lower than the freezing point of $p$-TolSCl, $p$-TolSCl was added directly into the reaction mixture to prevent it from freezing on the flask wall. The characteristic yellow color of $p$-TolSCl in the reaction solution dissipated within a few seconds, indicating depletion of $p$-TolSCl. After the donor was completely consumed, according to TLC analysis (about $5 \mathrm{~min}$ at $-78{ }^{\circ} \mathrm{C}$ ), a solution of acceptor $2(42 \mu \mathrm{mol})$ in $\mathrm{CH}_{2} \mathrm{Cl}_{2}(1 \mathrm{~mL})$ was slowly added along the wall by using a syringe. The reaction mixture was warmed to $-30{ }^{\circ} \mathrm{C}$ under 
stirring in $2 \mathrm{~h}$ and then room temperature. The second acceptor 3 (30 $\mu \mathrm{mol})$ in $\mathrm{CH}_{2} \mathrm{Cl}_{2}(1 \mathrm{~mL})$ was added, and the mixture was stirred for $5 \mathrm{~min}$ at room temperature. The mixture was then cooled to $-78^{\circ} \mathrm{C}$, followed by addition of $\operatorname{AgOTf}(37 \mathrm{mg}, 144 \mu \mathrm{mol})$ in $\mathrm{MeCN}(37 \mu \mathrm{L})$. The mixture was stirred for $20 \mathrm{~min}$, and then $p$-TolSCl $(6.7 \mu \mathrm{L}$, $42 \mu \mathrm{mol}$ ) was added to the solution. The reaction mixture was warmed to $-30{ }^{\circ} \mathrm{C}$ under stirring in $2 \mathrm{~h}$. Then, the mixture was diluted with $\mathrm{CH}_{2} \mathrm{Cl}_{2}(20 \mathrm{~mL})$ and filtered over Celite. The Celite was further washed with $\mathrm{CH}_{2} \mathrm{Cl}_{2}$ until no organic compounds were observed in the filtrate by TLC analysis. All solutions in $\mathrm{CH}_{2} \mathrm{Cl}_{2}$ were combined and washed twice with a saturated aqueous solution of $\mathrm{NaHCO}_{3}(20 \mathrm{~mL})$ and twice with water $(10 \mathrm{~mL})$. The organic layer was collected and dried over $\mathrm{Na}_{2} \mathrm{SO}_{4}$. After removal of the solvent, the desired oligosaccharide 10 was purified from the reaction mixture in a yield of $67 \%$ by silica gel flash chromatography.

$\mathrm{N}$-(Benzyl)-benzyloxycarbonyl-3-aminopropyl 6-O-Acetyl-2azido-3-O-benzyl-4-O-tert-butyldimethylsilyl-2-deoxy- $\alpha$-D-glucopyranosyl-(1 $\rightarrow 4)-2-0$-benzoyl-3-O-benzyl-6-levulinoyl- $\alpha-L-$ idopyranoside-(1 $\rightarrow 4)-6-O-a c e t y l-2-a z i d o-3-O-b e n z y l-2-d e o x y-\alpha-D-$ glucopyranosyl-(1 $\rightarrow 4)-2-0-$ benzoyl-3-O-benzyl-6-levulinoyl-1-thio$\alpha$-L-idopyranoside (11). Compound 11 was synthesized in $75 \%$ yield from $403 \mathrm{mg}(0.4 \mathrm{mmol})$ of donor 1 and $403 \mathrm{mg}(0.38 \mathrm{mmol})$ of acceptor 3 following the general procedure for glycosylation and was purified by silica gel flash chromatography (1:1:1 hexanes:DCM:EtOAc). This provided $548 \mathrm{mg}$ of $11 .{ }^{1} \mathrm{H}$ NMR $\delta_{\mathrm{H}}\left(500 \mathrm{MHz}, \mathrm{CDCl}_{3}\right)$ 8.15-8.11 (4 H, m), 7.39-7.32 (36 H, m), 5.17 (3 H, d, J 4.2), 5.13 $(2 \mathrm{H}, \mathrm{s}), 4.97-4.93(1 \mathrm{H}, \mathrm{m}), 4.79-4.71(7 \mathrm{H}, \mathrm{m}), 4.51(3 \mathrm{H}, \mathrm{t}, J 12.1)$, 4.42-4.36 (7 H, m), 4.27-4.23 (2 H, m), 4.15-4.09 (4 H, m), 3.98 (1 H, d, J 10.2), 3.89-3.83 (1 H, m), 3.78-7.73 (3 H, m), $3.66(1 \mathrm{H}, \mathrm{s})$, $3.60(2 \mathrm{H}, \mathrm{td}, J 9.6,5.0), 3.51(2 \mathrm{H}, \mathrm{t}, J 9.3), 3.38-3.34(3 \mathrm{H}, \mathrm{m}), 3.31-$ $3.25(2 \mathrm{H}, \mathrm{m}), 2.72-2.68(4 \mathrm{H}, \mathrm{m}), 2.55-2.50(4 \mathrm{H}, \mathrm{m}), 2.14(6 \mathrm{H}, \mathrm{s})$, $2.05(3 \mathrm{H}, \mathrm{s}), 2.02(3 \mathrm{H}, \mathrm{s}), 1.91-1.88(2 \mathrm{H}, \mathrm{m}), 0.92(9 \mathrm{H}, \mathrm{s}), 0.04$ $(3 \mathrm{H}, \mathrm{s}),-0.03(3 \mathrm{H}, \mathrm{s}) .{ }^{13} \mathrm{C}$ NMR $\delta_{\mathrm{C}}\left(125 \mathrm{MHz}, \mathrm{CDCl}_{3}\right) 206.3,172.24$, $172.17,170.68,170.65,165.6,165.4,156.6,156.1,137.92,137.88$, 137.77, 137.76, 137.6, 137.2, 136.8, 136.7, 133.4, 129.8, 129.5, 128.6, $128.5,128.39,128.35,128.30,128.13,128.11,128.03,128.00,127.9$, 127.83, 127.79, 127.6, 127.4, 127.3, 127.1, 98.6, 98.3, 98.2, 97.7, 80.3, 79.0, 75.4, 75.0, 74.85, 74.76, 74.6, 74.3, 73.5, 72.3, 72.2, 71.4, 71.0, 70.5, 70.1, 68.6, 67.9, 67.1, 65.6, 65.4, 65.3, 64.2, 63.8, 63.4, 62.8, 62.3, 62.1, 51.0, 50.7, 44.8, 43.8, 37.8, 29.82, 29.80, 28.3, 27.8, 27.7, 25.9, 20.8, 20.7, $18.0,-3.8,-5.0 .{ }^{1} J_{\mathrm{C} 1 \mathrm{AH} 1 \mathrm{~A}}=169 \mathrm{~Hz},{ }^{1} J_{\mathrm{C} 1 \mathrm{BH} 1 \mathrm{~B}}=170.5 \mathrm{~Hz},{ }^{1} J_{\mathrm{C} 1 \mathrm{CH} 1 \mathrm{C}}=$ $171.5 \mathrm{~Hz},{ }^{1} J_{\mathrm{C} 1 \mathrm{DH} 1 \mathrm{D}}=174 \mathrm{~Hz}$. HRMS $[\mathrm{M}+\mathrm{H}]^{+} \mathrm{C}_{104} \mathrm{H}_{122} \mathrm{~N}_{7} \mathrm{O}_{29} \mathrm{Si}^{+}$calcd. 1961.8084, obsd. 1961.8092 .

$\mathrm{N}$-(Benzyl)-benzyloxycarbonyl-3-aminopropyl 6-O-Acetyl-2azido-3-O-benzyl-4-O-tert-butyldimethylsilyl-2-deoxy- $\alpha$-D-glucopyranosyl-( $1 \rightarrow 4)$-benzyl 2-O-Benzoyl-3-O-benzyl- $\alpha$-L-idopyranosyluronate-(1 $\rightarrow 4)-6-O$-acetyl-2-azido-3-O-benzyl-2-deoxy- $\alpha$ - $D$ glucopyranosyl- $(1 \rightarrow 4)$-benzyl 2-O-Benzoyl-3-O-benzyl- $\alpha-L$ idopyranosyluronate- $(1 \rightarrow 4)-6$-O-acetyl-2-azido-3-O-benzyl-2deoxy- $\alpha$-D-glucopyranosyl-( $1 \rightarrow 4)$-benzyl 2-O-Benzoyl-3-O-benzyl$\alpha$-L-idopyranosyluronate (12). Compound 12 was prepared in two steps starting by treating compound $10(300 \mathrm{mg}, 110 \mu \mathrm{mol})$ to remove levulinoyl esters using the general procedure. This provided $239 \mathrm{mg}$ of $\mathrm{N}$-(benzyl)-benzyloxycarbonyl-3-aminopropyl 6-O-acetyl-2-azido-3-Obenzyl-4-O-tert-butyldimethylsilyl-2-deoxy- $\alpha$-D-glucopyranosyl-( $1 \rightarrow 4)$ 2-O-benzoyl-3-O-benzyl- $\alpha$-L-idopyranoside-( $(1 \rightarrow 4)$-6-O-acetyl-2-azido3-O-benzyl-2-deoxy- $\alpha$-D-glucopyranosyl-( $1 \rightarrow 4)$-2-O-benzoyl-3-O-benzyl- $\alpha$-L-idopyranoside-(1 $\rightarrow 4)-6-O$-acetyl-2-azido-3-O-benzyl-2-deoxy$\alpha$-D-glucopyranosyl-( $1 \rightarrow 4)$-2-O-benzoyl-3-O-benzyl- $\alpha$-L-idopyranoside in $87 \%$ yield after silica gel chromatography (1:1:2 hexanes:DCM:EtOAC then 1:1:3 hexanes:DCM:EtOAC). ${ }^{1} \mathrm{H}$ NMR $\delta_{\mathrm{H}}(600 \mathrm{MHz}$, $\left.\mathrm{CDCl}_{3}\right)$ 8.15-8.09 (6 H, m), 7.48-7.12 (49 H, m), 5.19-5.12 (4 H, m), 5.09 ( $1 \mathrm{H}, \mathrm{d}, J 14.8), 5.07-5.04(2 \mathrm{H}, \mathrm{m}), 5.03-4.91(1 \mathrm{H}, \mathrm{m}), 4.90-$ $4.80(3 \mathrm{H}, \mathrm{m}), 4.72(5 \mathrm{H}, \mathrm{ddd}, J 12.7,11.5,7.3), 4.57(1 \mathrm{H}, \mathrm{m}), 4.53-$ $4.27(9 \mathrm{H}, \mathrm{m}), 4.27-4.19(3 \mathrm{H}, \mathrm{m}), 4.19-4.13(3 \mathrm{H}, \mathrm{m}), 4.07-4.03$ $(3 \mathrm{H}, \mathrm{m}), 4.02-3.73(9 \mathrm{H}, \mathrm{m}), 3.72-3.47(11 \mathrm{H}, \mathrm{m}), 3.45-3.40(1 \mathrm{H}, \mathrm{m})$, $3.26(2 \mathrm{H}, \mathrm{dd}, J 10.1,3.7), 3.23(2 \mathrm{H}, \mathrm{dd}, J 11.3,5.3), 3.23(2 \mathrm{H}, \mathrm{dd}, J$ $11.3,5.3), 2.03(3 \mathrm{H}, \mathrm{s}), 2.02(3 \mathrm{H}, \mathrm{s}), 2.01(3 \mathrm{H}, \mathrm{s}), 1.95-1.80(2 \mathrm{H}, \mathrm{m})$, $0.87(9 \mathrm{H}, \mathrm{s}),-0.01(3 \mathrm{H}, \mathrm{s}),-0.09(3 \mathrm{H}, \mathrm{s})$. HRMS $[\mathrm{M}+\mathrm{H}]^{+}$ $\mathrm{C}_{129} \mathrm{H}_{147} \mathrm{~N}_{10} \mathrm{O}_{36} \mathrm{Si}^{+}$calcd. 2440.9777, obsd. 2440.9768. N-(Benzyl)benzyloxycarbonyl-3-aminopropyl 6-O-acetyl-2-azido-3-O-benzyl-4-O- tert-butyldimethylsilyl-2-deoxy- $\alpha$-D-glucopyranosyl-( $1 \rightarrow 4)$-2-O-benzoyl-3-O-benzyl- $\alpha$-L-idopyranoside- $(1 \rightarrow 4)$-6- $O$-acetyl-2-azido-3-O-benzyl-2-deoxy- $\alpha$-D-glucopyranosyl-( $1 \rightarrow 4)$-2-O-benzoyl-3-O-benzyl- $\alpha$-Lidopyranoside- $(1 \rightarrow 4)-6$ - $O$-acetyl-2-azido-3-O-benzyl-2-deoxy- $\alpha$-Dglucopyranosyl-( $1 \rightarrow 4)$-2-O-benzoyl-3-O-benzyl- $\alpha$-L-idopyranoside $(27 \mathrm{mg}, 11 \mu \mathrm{mol})$ was oxidized, and the resulting carboxylates were protected as benzyl esters according to the general procedures to produce $27 \mathrm{mg}$ of compound 12 in $80 \%$ yield after silica gel chromatography (3:1 hexanes:EtOAc). ${ }^{1} \mathrm{H}$ NMR $\delta_{\mathrm{H}}(500 \mathrm{MHz}$, $\left.\mathrm{CDCl}_{3}\right)$ 8.30-8.22 (6 H, m), 7.74-7.23 $(64 \mathrm{H}, \mathrm{m}), 5.69(1 \mathrm{H}, \mathrm{d}$, J 5.3), $5.62(1 \mathrm{H}, \mathrm{d}, J$ 5.4), 5.39-5.32 (3 H, m), 5.31-5.11 (10 H, m), 5.03-4.77 $(11 \mathrm{H}, \mathrm{m}), 4.63-4.36(11 \mathrm{H}, \mathrm{m}), 4.34-4.30(2 \mathrm{H}, \mathrm{m}), 4.27-$ $4.20(4 \mathrm{H}, \mathrm{m}), 4.10(2 \mathrm{H}, \mathrm{t}, J 5.6), 4.05(1 \mathrm{H}, \mathrm{d}, J 9.9), 4.02-3.98(3 \mathrm{H}$, m), 3.93-3.81 (3 H, m), $3.78(1 \mathrm{H}, \mathrm{t}, J 9.1), 3.66-3.61(1 \mathrm{H}, \mathrm{m}), 3.61-$ $3.53(3 \mathrm{H}, \mathrm{m}), 3.53-3.41(2 \mathrm{H}, \mathrm{m}), 3.38(1 \mathrm{H}, \mathrm{dd}, J 10.2,3.7), 3.33(1 \mathrm{H}$, dd, J 10.2, 3.7), 3.28 (1 H, dd, J 10.2, 3.6), $2.20(4 \mathrm{H}, \mathrm{s}, J 0.7), 2.18(3 \mathrm{H}$, $\mathrm{s}, J 5.0), 2.14(3 \mathrm{H}, \mathrm{s}), 2.00-1.87(2 \mathrm{H}, \mathrm{m}), 1.04(9 \mathrm{H}, \mathrm{s}), 0.17(3 \mathrm{H}, \mathrm{s})$, $0.10(3 \mathrm{H}, \mathrm{s}) .{ }^{13} \mathrm{C} \mathrm{NMR}\left(150 \mathrm{MHz}, \mathrm{CDCl}_{3}\right) \delta 172.0,171.3,171.0,170.8$, 169.2, 165.6, 165.4, 165.4, 138.1, 138.1, 138.0, 137.5, 137.4, 135.4, 135.3, 135.0, 133.9, 133.8, 130.23, 130.19, 130.1, 129.5, 129.4, 129.1, 129.04, $129.01,128.98,128.95,128.94,128.91,128.90,128.87,128.84,128.82$, $128.78,128.72,128.71,128.66,128.63,128.61,128.59,128.58,128.5$, $128.39,128.37,128.34,128.30,128.21,128.17,128.14,128.13,128.1$, $128.01,128.00,127.8,127.6,100.1,99.5,99.2,98.6,98.5,79.4,78.5$, 78.4, 76.2, 76.0, 75.3, 75.1, 75.0, 74.47, 74.45, 74.3, 73.4, 72.6, 71.8, 71.4, 71.3, 70.7, 70.2, 69.9, 68.1, 67.9, 67.2, 63.7, 63.4, 63.1, 62.7, 62.1, 60.6, 21.3, 21.0, 14.4. MALDI $[\mathrm{M}+\mathrm{Na}]^{+} \mathrm{C}_{129} \mathrm{H}_{146} \mathrm{~N}_{10} \mathrm{NaO}_{36} \mathrm{Si}^{+}$calcd. 2775.0, obsd. 2775.3.

$N$-(Benzyl)-benzyloxycarbonyl-3-aminopropyl 6-O-Acetyl-2azido-3-O-benzyl-4-O-tert-butyldimethylsilyl-2-deoxy- $\alpha$-D-glucopyranosyl-(1 $\rightarrow 4)$-methyl 2-O-Benzoyl-3-O-benzyl- $\alpha$-L-idopyranosyluronate- $(1 \rightarrow 4)$-6-O-acetyl-2-azido-3-O-benzyl-2-deoxy- $\alpha$ - $D$ glucopyranosyl-(1 $\rightarrow 4)$-methyl 2-O-Benzoyl-3-O-benzyl- $\alpha-L-$ idopyranosyluronate-(1 $\rightarrow 4)-6$-O-acetyl-2-azido-3-0-benzyl-2deoxy- $\alpha$-D-glucopyranosyl- $(1 \rightarrow 4)$-methyl 2-O-Benzoyl-3-O-benzyl$\alpha$-L-idopyranosyluronate (14). Compound 14 was prepared from $30 \mathrm{mg}(12 \mu \mathrm{mol})$ of $\mathrm{N}$-(benzyl)-benzyloxycarbonyl-3-aminopropyl 6-O-acetyl-2-azido-3-O-benzyl-4-O-tert-butyldimethylsilyl-2-deoxy- $\alpha$-Dglucopyranosyl-( $1 \rightarrow 4)$-2-O-benzoyl-3-O-benzyl- $\alpha$-L-idopyranoside$(1 \rightarrow 4)$-6-O-acetyl-2-azido-3-O-benzyl-2-deoxy- $\alpha$-D-glucopyranosyl$(1 \rightarrow 4)$-2-O-benzoyl-3-O-benzyl- $\alpha$-L-idopyranoside-( $1 \rightarrow 4)$-6-O-acetyl2-azido-3-O-benzyl-2-deoxy- $\alpha$-D-glucopyranosyl- $(1 \rightarrow 4)$-2-O-benzoyl3 -O-benzyl- $\alpha$-L-idopyranoside using the general procedure for oxidation and methyl ester formation. Compound $\mathbf{1 4}$ was isolated in $77 \%$ yield (24 mg) after silica gel chromatography (3:2 hexanes:EtOAc). ${ }^{1} \mathrm{H}$ NMR $\delta_{\mathrm{H}}\left(500 \mathrm{MHz}, \mathrm{CDCl}_{3}\right) 8.21-8.07(6 \mathrm{H}, \mathrm{m}), 7.61-7.05(49 \mathrm{H}, \mathrm{m}), 5.57$ (1 H, d, J 5.9), 5.47 (1 H, d, J 5.7), $5.24(1 \mathrm{H}, \mathrm{t}, J 6.3), 5.19$ (1 H, t, J 6.1), $5.15(2 \mathrm{H}, \mathrm{s}), 5.07(3 \mathrm{H}, \mathrm{d}, J 3.5), 4.92(1 \mathrm{H}, \mathrm{d}, J 3.6), 4.87-4.76(5 \mathrm{H}$, m), $4.73(4 \mathrm{H}, \mathrm{dd}, J 10.8,7.3), 4.69-4.60(4 \mathrm{H}, \mathrm{m}), 4.51-4.33(7 \mathrm{H}, \mathrm{m})$, 4.27 (3 H, dt, J 16.7, 11.4), 4.19-4.13 (2 H, m), 4.12-4.05 (4 H, m), $3.98(1 \mathrm{H}, \mathrm{s}), 3.96-3.92(1 \mathrm{H}, \mathrm{m}), 3.90(2 \mathrm{H}, \mathrm{d}, J 9.1), 3.87-3.83(1 \mathrm{H}$, m), 3.79 (4 H, dd, J 10.7, 7.4), 3.71 (3 H, d, J 5.4), 3.70-3.65 (1 H, m), 3.61-3.55 (4 H, m), 3.53-3.49 (1 H, m), 3.47-3.41 (4 H, m), 3.33$3.26(3 \mathrm{H}, \mathrm{m}), 3.21(1 \mathrm{H}, \mathrm{dd}, J 10.2,3.5), 2.12(3 \mathrm{H}, \mathrm{s}, J 3.3), 2.11(3 \mathrm{H}, \mathrm{s})$, $2.03(3 \mathrm{H}, \mathrm{s}), 1.82(2 \mathrm{H}, \mathrm{d}), 0.92(9 \mathrm{H}, \mathrm{s}), 0.03(3 \mathrm{H}, \mathrm{s}),-0.00(3 \mathrm{H}, \mathrm{s})$. ${ }^{13} \mathrm{C}$ NMR $\delta_{\mathrm{C}}\left(125 \mathrm{MHz}, \mathrm{CDCl}_{3}\right) 170.7,170.64,170.56,169.7,169.5$, 165.6 , 165.2, 165.1, 137.8, 137.7, 137.34, 137.30, 133.7, 133.6, 133.4, $130.0,129.9,129.8,129.2,129.1,128.8,128.7,128.52,128.45,128.36$, $128.3,128.2,128.01,127.98,127.92,127.88,127.84,127.76,127.7$, 127.6, 127.4, 127.2, 99.0, 98.72, 98.66, 98.1, 98.0, 80.2, 78.2, 78.1, 76.5, 76.2, 76.0, 75.0, 74.9, 74.7, 74.6, 74.5, 74.4, 74.1, 72.6, 72.2, 72.0, 71.6, $71.4,71.2,71.1,70.6,69.7,69.6,68.0,67.5,67.2,63.8,63.4,63.0,62.4$, 61.6, 52.1, 51.9, 51.7, 25.9, 20.81, 20.78, 18.0, -3.7, -5.1. HRMS $[\mathrm{M}+\mathrm{H}]^{+} \mathrm{C}_{132} \mathrm{H}_{147} \mathrm{~N}_{10} \mathrm{O}_{39} \mathrm{Si}^{+}$calcd. 2524.9624, obsd. 2524.9628 .

$\mathrm{N}$-(Benzyl)-benzyloxycarbonyl-3-aminopropyl 2-Azido-3-O-benzyl-4-O-tert-butyldimethylsilyl-2-deoxy- $\alpha$-D-glucopyranosyl-( $1 \rightarrow 4)$ methyl 3-O-Benzyl- $\alpha$-L-idopyranosyluronate- $(1 \rightarrow 4)-2$-azido-3-Obenzyl-2-deoxy- $\alpha$-D-glucopyranosyl- $(1 \rightarrow 4)$-methyl 3-O-Benzyl- $\alpha$ - Lidopyranosyluronate- $(1 \rightarrow 4)$-2-azido-3-O-benzyl-2-deoxy- $\alpha$-Dglucopyranosyl-(1 $\rightarrow 4)$-methyl 3-O-Benzyl- $\alpha$-L-idopyranosyluronate (15). Compound 15 was prepared from $24 \mathrm{mg}$ of 14 (9.5 $\mu \mathrm{mol})$ using 
the general procedure for transesterification, and $18 \mathrm{mg}$ of 15 was isolated (91\% yield) after elution from a Sephadex LH-20 column (1:1 DCM:MeOH). ${ }^{1} \mathrm{H}$ NMR $\delta_{\mathrm{H}}\left(500 \mathrm{MHz}, \mathrm{CDCl}_{3}\right) 7.45-7.09(40 \mathrm{H}, \mathrm{m})$, $5.28(1 \mathrm{H}, \mathrm{s}), 5.25(1 \mathrm{H}, \mathrm{d}, J 1.7), 5.17(2 \mathrm{H}, \mathrm{s}), 5.04-4.95(4 \mathrm{H}, \mathrm{m})$, 4.90-4.78 (6 H, m), 4.78-4.68 (5 H, m), $4.62(3 \mathrm{H}, \mathrm{dd}, J$ 11.2, 2.7), 4.60-4.49 (4 H, m), 4.49-4.43 (2 H, m), $4.15(1 \mathrm{H}, \mathrm{s}), 4.04(2 \mathrm{H}, \mathrm{d}$, J 2.9), 3.96-3.83 (6 H, m), 3.83-3.70 (12 H, m), 3.68-3.48 (10 H, m), $3.46(1 \mathrm{H}, \mathrm{dd}, J 9.8,3.7), 3.42(3 \mathrm{H}, \mathrm{s}), 3.40-3.35(2 \mathrm{H}, \mathrm{m}), 1.89-1.80$ $(2 \mathrm{H}, \mathrm{m}), 0.87(9 \mathrm{H}, \mathrm{s}), 0.07(3 \mathrm{H}, \mathrm{s}),-0.03(3 \mathrm{H}, \mathrm{s}) .{ }^{13} \mathrm{C}$ NMR $\delta_{\mathrm{C}}$ $\left(125 \mathrm{MHz}, \mathrm{CDCl}_{3}\right)$ 169.6, 169.4, 137.8, 137.6, 137.04, 137.01, 128.72, $128.69,128.5,128.45,128.39,128.35,128.27,128.26,128.2,128.1$, $128.0,127.8,127.7,127.4,127.3,127.24,127.23,127.1,101.8,100.92$, $100.88,95.6,95.4,80.8,79.3,79.1,75.5,75.1,75.0,74.2,74.0,73.4,73.1$, $73.0,72.81,72.75,72.6,72.5,72.2,71.8,70.4,68.1,67.9,67.7,67.4$ 67.25, 66.20, 64.4, 64.2, 64.0, 61.3, 61.2, 61.0, 52.4, 52.13, 52.07, 25.8, 17.9, -3.8, -4.8. HRMS $[\mathrm{M}+\mathrm{H}]^{+} \mathrm{C}_{105} \mathrm{H}_{129} \mathrm{~N}_{10} \mathrm{O}_{33} \mathrm{Si}^{+}$calcd. 2086.8521, obsd. 2086.8518.

$\mathrm{N}$-(Benzyl)-benzyloxycarbonyl-3-aminopropyl 6-O-Acetyl-2azido-3-O-benzyl-2-deoxy- $\alpha$-D-glucopyranosyl- $(1 \rightarrow 4)$-methyl 2-OBenzoyl-3-O-benzyl- $\alpha$-L-idopyranosyluronate- $(1 \rightarrow 4)-6$-O-acetyl-2azido-3-O-benzyl-2-deoxy- $\alpha$-D-glucopyranosyl- $(1 \rightarrow 4)$-methyl 2-OBenzoyl-3-O-benzyl- $\alpha$-L-idopyranosyluronate- $(1 \rightarrow 4)-6$-O-acetyl-2azido-3-O-benzyl-2-deoxy- $\alpha$-D-glucopyranosyl-( $1 \rightarrow 4)$-methyl 2-OBenzoyl-3-O-benzyl- $\alpha$-L-idopyranosyluronate (17). Compound 17 was prepared from compound $14(211 \mathrm{mg}, 83.6 \mu \mathrm{mol})$ by removing the TBS protecting group according to the general procedure furnishing $179 \mathrm{mg}$ of 17 , a $94 \%$ yield after silica gel chromatography (1:1 hexanes:EtOAc). ${ }^{1} \mathrm{H}$ NMR $\delta_{\mathrm{H}}\left(500 \mathrm{MHz}, \mathrm{CDCl}_{3}\right) 8.17-8.10(6 \mathrm{H})$, 7.60-7.09 (49 H, m), $5.52(1 \mathrm{H}, \mathrm{d}, J 5.3), 5.47(1 \mathrm{H}, \mathrm{d}, J 5.5), 5.24-5.21$ $(1 \mathrm{H}, \mathrm{m}), 5.21-5.17(1 \mathrm{H}, \mathrm{m}), 5.15(2 \mathrm{H}, \mathrm{s}), 5.07(2 \mathrm{H}, \mathrm{s}), 5.01(1 \mathrm{H}, \mathrm{d}$, J 3.5), $4.92(1 \mathrm{H}, \mathrm{d}, J 3.6), 4.84-4.61(11 \mathrm{H}, \mathrm{m}), 4.59-4.53(2 \mathrm{H}, \mathrm{m})$, 4.48-4.39 (5 H, m), 4.32-4.23 (3 H, m), 4.21-4.06 (7 H, m), 4.00$3.84(6 \mathrm{H}, \mathrm{m}), 3.83-3.76(3 \mathrm{H}, \mathrm{m}), 3.65(3 \mathrm{H}, \mathrm{s}), 3.62-3.55(5 \mathrm{H}, \mathrm{m})$, 3.51-3.41 (6 H, m), $3.31(2 \mathrm{H}, \mathrm{dd}, J 10.3,3.6), 3.22(2 \mathrm{H}$, ddd, J 10.3, 3.5, 1.6), $2.94(1 \mathrm{H}, \mathrm{s}), 2.11(3 \mathrm{H}, \mathrm{s}), 2.10(3 \mathrm{H}, \mathrm{s}), 2.08(3 \mathrm{H}, \mathrm{s}), 1.84$ $(2 \mathrm{H}, \mathrm{bs}) .{ }^{13} \mathrm{C}$ NMR $\delta_{\mathrm{C}}\left(125 \mathrm{MHz}, \mathrm{CDCl}_{3}\right) 171.9,170.8,170.7,169.6$, $169.5,165.6,165.2$, 137.8, 137.73, 137.70, 137.3, 137.2, 133.7, 133.6, $133.4,130.0,129.9,129.6,129.2,129.1,128.8,128.7,128.6,128.5$, $128.39,128.37,128.3,128.2,128.08,128.06,128.02,127.99,127.97$, $127.95,127.9,127.71,127.67,127.4,127.3,99.3,99.0,98.6,98.2,98.1$, 78.9, 78.3, 78.2, 76.2, 76.0, 75.9, 75.7, 75.0, 74.9, 74.7, 74.62, 74.57, 74.3, $74.1,72.7,72.2,71.4,71.1,71.0,70.4,69.8,69.6,68.0,67.5,67.2,63.4$, 63.1, 62.9, 62.5, 61.74, 61.66, 60.4, 52.1, 52.0, 51.7, 29.7, 20.80, 20.78, 20.77. HRMS $[\mathrm{M}+\mathrm{H}]^{+} \mathrm{C}_{126} \mathrm{H}_{133} \mathrm{~N}_{10} \mathrm{O}_{39}{ }^{+}$calcd. 2410.8759, obsd. 2410.8751

$\mathrm{N}$-(Benzyl)-benzyloxycarbonyl-3-aminopropyl 6-O-Acetyl-2azido-3,4-di-O-benzyl-2-deoxy- $\alpha$-D-glucopyranosyl-( $1 \rightarrow 4)$-methyl 2-O-Benzoyl-3-O-benzyl- $\alpha$-L-idopyranosyluronate- $(1 \rightarrow 4)-6$-O-acetyl-2-azido-3-O-benzyl-2-deoxy- $\alpha$-D-glucopyranosyl-( $1 \rightarrow 4)$-methyl 2-O-Benzoyl-3-O-benzyl- $\alpha$-L-idopyranosyluronate- $(1 \rightarrow 4)-6-O-a c e-$ tyl-2-azido-3-O-benzyl-2-deoxy- $\alpha$-D-glucopyranosyl- $(1 \rightarrow 4)$-methyl 2-O-Benzoyl-3-O-benzyl- $\alpha$-L-idopyranosyluronate (18). Compound 18 was prepared from compound $17(18 \mathrm{mg}, 7.5 \mu \mathrm{mol})$ using the general procedure for benzylation to provide $10 \mathrm{mg}$ of 18 in $50 \%$ yield (66\% BRSM with $3 \mathrm{mg}$ of 17 recovered) after silica gel chromatography (3:2 hexanes:EtOAc). ${ }^{1} \mathrm{H}$ NMR $\delta_{\mathrm{H}}\left(500 \mathrm{MHz}, \mathrm{CDCl}_{3}\right) 8.14-8.08$ $(6 \mathrm{H}), 7.58-7.07(54 \mathrm{H}, \mathrm{m}), 5.49(1 \mathrm{H}, \mathrm{d}, J 4.8), 5.45(1 \mathrm{H}, \mathrm{d}, J 5.5), 5.17$ $(2 \mathrm{H}$, ddd, $J$ 8.8, 5.9, 2.5), $5.13(2 \mathrm{H}, \mathrm{d}, J 3.0), 5.04(2 \mathrm{H}, \mathrm{s}), 4.96(1 \mathrm{H}, \mathrm{d}$, J3.5), $4.89(1 \mathrm{H}, \mathrm{d}, J 3.6), 4.83-4.75(6 \mathrm{H}, \mathrm{m}), 4.72(3 \mathrm{H}, \mathrm{dd}, J 17.9,7.0)$, $4.66(2 \mathrm{H}, \mathrm{dd}, J 6.2,4.2), 4.57(1 \mathrm{H}, \mathrm{d}, J 10.9), 4.48(1 \mathrm{H}, \mathrm{d}, J 10.6), 4.41$ ( $5 \mathrm{H}, \mathrm{dd}, J$ 18.2, 7.9), 4.32-4.18 (6 H, m), 4.16-4.11 (2 H, m), 4.06 ( $3 \mathrm{H}$, ddd, J 8.0, 5.8, 2.7), 3.98-3.92 (3 H, m), $3.88(2 \mathrm{H}, \mathrm{t}, J 9.5), 3.81-$ $3.72(4 \mathrm{H}, \mathrm{m}), 3.69-3.62(4 \mathrm{H}, \mathrm{m}), 3.61-3.54(4 \mathrm{H}, \mathrm{m}), 3.54-3.49$ $(1 \mathrm{H}, \mathrm{m}), 3.48-3.42(5 \mathrm{H}, \mathrm{m}), 3.37-3.26(3 \mathrm{H}, \mathrm{m}), 3.24(1 \mathrm{H}, \mathrm{dd}, J 10.3$, 3.5), $3.20(1 \mathrm{H}, \mathrm{dd}, J 10.2,3.6), 2.12-2.06(6 \mathrm{H}, \mathrm{m}), 1.99-1.95(3 \mathrm{H}$, $\mathrm{m}), 1.85-1.76(2 \mathrm{H}, \mathrm{m}) .{ }^{13} \mathrm{C} \mathrm{NMR}\left(125 \mathrm{MHz}, \mathrm{CDCl}_{3}\right) \delta 170.63$, $170.58,170.4,169.5,169.45,165.5,165.2,165.1,137.8,137.6,137.5$, $137.3,137.2,133.6,133.4,130.0,129.9,129.6,129.2,129.1,128.8,128.7$, $128.5,128.45,128.4,128.36,128.3,128.2,128.1,128.01,127.99,127.96$, 127.9, 127.88, 127.86, 127.7, 127.4, 127.2, 99.1, 99.0, 98.6, 98.3, 98.1, 80.0, 78.3, 78.26, 77.4, 76.0, 75.9, 75.7, 75.5, 75.0, 74.99, 74.8, 74.6,
$74.56,74.3,74.1,72.7,72.2,71.4,70.9,70.85,70.5,70.1,69.7,69.6,68.0$, 67.5, 67.3, 64.3, 63.4, 63.37, 63.1, 62.2, 61.7, 52.1, 52.0, 51.7, 20.8, 20.75. HRMS $[\mathrm{M}+\mathrm{H}]^{+} \mathrm{C}_{133} \mathrm{H}_{139} \mathrm{~N}_{10} \mathrm{O}_{39}{ }^{+}$calcd. 2500.9229, obsd. 2500.9230.

$\mathrm{N}$-(Benzyl)-benzyloxycarbonyl-3-aminopropyl 2-Amino-3,4-di-Obenzyl-2-deoxy- $\alpha$-D-glucopyranosyl-(1 $\rightarrow 4)$-methyl 3-O-Benzyl- $\alpha$-Lidopyranosyluronate- $(1 \rightarrow 4)$-2-amino-3-O-benzyl-2-deoxy- $\alpha-D$ glucopyranosyl- $(1 \rightarrow 4)$-methyl 3-O-Benzyl- $\alpha$-L-idopyranosyluronate- $(1 \rightarrow 4)$-2-amino-3-O-benzyl-2-deoxy- $\alpha$-D-glucopyranosyl-(1 $\rightarrow 4)$-methyl 3-O-Benzyl- $\alpha$-L-idopyranosyluronate (19). Compound 19 was prepared by treating compound $18(12 \mathrm{mg}, 4.8 \mu \mathrm{mol})$ with the procedures for transesterification and 1,3-dithiopropane reduction. This furnished $7 \mathrm{mg}$ of compound 19, a $76 \%$ yield over two steps. The compound was purified via silica gel chromatography (DCM:MeOH $=8: 1$ with $5 \%$ triethylamine) after1,3-dithiopropane reduction. ${ }^{1} \mathrm{H}$ NMR $\delta_{\mathrm{H}}\left(500 \mathrm{MHz}, \mathrm{CDCl}_{3}\right) 7.38-7.17(44 \mathrm{H}, \mathrm{m}), 7.13-$ $7.10(1 \mathrm{H}, \mathrm{m}), 5.29(2 \mathrm{H}, \mathrm{dd}, J 8,3.5), 5.15(2 \mathrm{H}, \mathrm{s}), 4.99(1 \mathrm{H}, \mathrm{d}, J 12)$, 4.97-4.92 (5 H, m), 4.91-4.87 (3 H, m), $4.86(1 \mathrm{H}, \mathrm{d}, J 3), 4.81(2 \mathrm{H}, \mathrm{d}$, $J 11.5), 4.72(2 \mathrm{H}, \mathrm{dd}, J 11.5,3.5), 4.66(4 \mathrm{H}, \mathrm{s}), 4.64(2 \mathrm{H}, \mathrm{d}, J 11), 4.58$ (2 H, d, J 11.5), 4.54-4.43 (4 H, m), $4.41(2 \mathrm{H}, \mathrm{d}, J 11.5), 4.22-4.15$ $(3 \mathrm{H}, \mathrm{m}), 4.02-3.96(2 \mathrm{H}, \mathrm{m}), 3.94(2 \mathrm{H}, \mathrm{s}), 3.91-3.82(4 \mathrm{H}, \mathrm{m}), 3.82-$ $3.75(5 \mathrm{H}, \mathrm{m}), 3.74(3 \mathrm{H}, \mathrm{s}), 3.73-3.70(2 \mathrm{H}, \mathrm{m}), 3.68-3.65(2 \mathrm{H}, \mathrm{m})$, $3.55(3 \mathrm{H}, \mathrm{s}), 3.53(3 \mathrm{H}, \mathrm{s}), 3.51-3.34(10 \mathrm{H}, \mathrm{m}), 3.32-3.24(2 \mathrm{H}, \mathrm{m})$, $2.90-2.83(2 \mathrm{H}, \mathrm{m}), 1.88-1.78(2 \mathrm{H}, \mathrm{m}) .{ }^{13} \mathrm{C} \mathrm{NMR}\left(125 \mathrm{MHz}, \mathrm{CDCl}_{3}\right)$ $\delta 170.2,170.14,170.11,156.7,156.2,141.1,138.49,138.43,138.2$, $138.0,137.8,137.7,137.6,137.40,137.38,136.8,136.6,128.6,128.54$, $128.51,128.50,128.48,128.46,128.41,128.30,128.28,128.03,127.99$ $127.95,127.90,127.83,127.81,127.78,127.70,127.64,127.58,127.47$, $127.3,127.1,126.96,126.95,126.93,101.9,101.4,101.3,97.0,96.8,82.8$, $81.3,78.0,75.8,75.3,75.00,74.96,74.5,72.7,72.6,72.21,72.16,71.7$, $70.9,69.8,69.7,69.2,67.5,67.2,66.6,66.1,65.0,61.3,60.8,55.3,55.1$, $52.4,52.0,51.9,50.8,50.5,44.6,43.8,27.9$. HRMS $[\mathrm{M}+\mathrm{H}]^{+}$ $\mathrm{C}_{106} \mathrm{H}_{127} \mathrm{~N}_{4} \mathrm{O}_{33}{ }^{+}$calcd. 1984.8411, obsd. 1984.8417.

3-Aminopropyl 2-Deoxy-2-amino-6-O-sulfonate- $\alpha$-D-glucopyranosyl-( $1 \rightarrow 4)$-2-O-sulfonate- $\alpha$-L-idopyranosyluronate- $(1 \rightarrow 4)-2$ deoxy-2-amino-6-O-sulfonate- $\alpha$-D-glucopyranosyl- $(1 \rightarrow 4)-2-0$-sulfonate- $\alpha$-L-idopyranosyluronate- $(1 \rightarrow 4)$-2-deoxy-2-amino-6-O-sulfonate- $\alpha$-D-glucopyranosyl-( $1 \rightarrow 4)-2-O$-sulfonate- $\alpha$-L-idopyranosyluronate Salt (20). Compound 20 was prepared from compound 19 $(6 \mathrm{mg}, 2.4 \mu \mathrm{mol})$ in 3 steps. Treatment with the general procedures for selective $O$-sulfation, global debenzylation, and methyl ester saponification provided $3 \mathrm{mg}$ of $\mathbf{2 0}$ in $72 \%$ yield from compound 19. NMR analysis showed that the anomeric carbons of the three glucosamine units of $\mathbf{2 5}$ gave chemical shifts of $93.0 \mathrm{ppm}$ ( 3 carbons), which suggests that the glucosamines were not sulfated. These values were consistent with literature reports, ${ }^{67,68}$ where anomeric carbons of unsulfated glucosamines in heparin resonate around $94 \mathrm{ppm}$, while those of $N$-sulfated glucosamines typically appear above $100 \mathrm{ppm} .{ }^{1} \mathrm{H}$ NMR $\delta_{\mathrm{H}}$ $\left(500 \mathrm{MHz}, \mathrm{D}_{2} \mathrm{O}\right) 5.37-5.29$ (3 H, m, H-1B, H-1D, H-1F), $5.15(1 \mathrm{H}, \mathrm{s}$, H-1A), 5.13 (1H, s, H-1C)5.05 (1 H, s, H-1E), 4.84 (2 H, dd, J 7.4, 1.3), $4.46(1 \mathrm{H}, \mathrm{d}, J 1.5), 4.31-4.25(5 \mathrm{H}, \mathrm{m}, \mathrm{H}-2 \mathrm{~A}, \mathrm{H} 2 \mathrm{C}, \mathrm{H}-3 \mathrm{E}), 4.21(4 \mathrm{H}$, s), 4.18-4.12 ( $2 \mathrm{H}, \mathrm{m}, \mathrm{H}-2 \mathrm{E}), 4.11-4.07$ ( $3 \mathrm{H}, \mathrm{m}, \mathrm{H}-3 \mathrm{~A}, \mathrm{H}-3 \mathrm{C}), 3.97-$ $3.91(2 \mathrm{H}, \mathrm{m}), 3.90-3.85(3 \mathrm{H}, \mathrm{m}, \mathrm{H}-3 \mathrm{~B}, \mathrm{H}-3 \mathrm{D}), 3.84-3.75(3 \mathrm{H}, \mathrm{m}$, H-3F), 3.74-3.68 (2 H, m), 3.66-3.61 (1 H, m), 3.48 (1 H, t, J 9.7), $3.35-3.25$ ( $3 \mathrm{H}, \mathrm{m}, \mathrm{H}-2 \mathrm{~B}, \mathrm{H}-2 \mathrm{D}, \mathrm{H}-2 \mathrm{~F}), 3.12-3.03(2 \mathrm{H}, \mathrm{m}), 1.96-1.87$ $(2 \mathrm{H}, \mathrm{m}) . \delta_{\mathrm{C}}$ (values obtained from $\mathrm{F} 1$ dimension of $\mathrm{HMQC}$ spectrum) $\delta 100.7$ (C-1C), 100.5 (C-1A), 99.8 (C-1E), 93.0 (C-1B, C-1D, C-1F), $77.7,77.3,77.2,74.6,72.2,72.1,71.4,71.2,70.6,70.5,70.4,70.1,69.0$, $68.6,68.1,68.0,64.5,56.2,55.9,55.0,40.2,27.9$; HRMS $[\mathrm{M}]^{3-}$ $\mathrm{C}_{39} \mathrm{H}_{63} \mathrm{~N}_{4} \mathrm{O}_{49} \mathrm{~S}_{6}{ }^{3-}$ calcd. 521.0301, obsd. 521.0304.

3-Aminopropyl 2-Deoxy-2-acetamido-6-O-sulfonate- $\alpha$-D-glucopyranosyl- $(1 \rightarrow 4)-2-0$-sulfonate- $\alpha$-L-idopyranosyluronate- $(1 \rightarrow 4)-2$ deoxy-2-acetamido-6-O-sulfonate- $\alpha$-D-glucopyranosyl-( $1 \rightarrow 4)-2-0$ sulfonate- $\alpha$-L-idopyranosyluronate- $(1 \rightarrow 4)$-2-deoxy-2-acetamido- 6 $O$-sulfonate- $\alpha$-D-glucopyranosyl- $(1 \rightarrow 4)-2$-O-sulfonate- $\alpha-L$ idopyranosyluronate (21). Compound 21 was prepared from 19 in four steps. 19 was first selectively sulfated using the procedure for selective $O$-sulfation, which was followed by acetylation. Next, $5 \mathrm{mg}$ of the sulfated product $(2 \mu \mathrm{mol})$ was dissolved in $2 \mathrm{~mL}$ of methanol. To this was added $30 \mu \mathrm{L}$ of triethylamine and 30 equiv of acetic anhydride (10 equiv per $\mathrm{NH}_{2}$ and $6 \mu \mathrm{L}$ total). This was stirred at room temperature for $5 \mathrm{~h}$ and was diluted with 1:1 DCM:MeOH and eluted 
from a Sephadex LH-20 column. The product of acetylation was further treated with global debenzylation and methyl ester saponification conditions to produce $2 \mathrm{mg}$ of $\mathbf{2 1}$ in 54\% yield over 4 steps from $\mathbf{1 9}$. NMR analysis showed that the anomeric carbons of the three glucosamine units of $\mathbf{2 1}$ gave chemical shifts of $95.6 \mathrm{ppm}$ (3 carbons), which suggests that the glucosamines were not sulfated. These values were consistent with literature reports, ${ }^{67,68}$ where anomeric carbons of unsulfated glucosamines in heparin resonate around $94 \mathrm{ppm}$, while those of $N$-sulfated glucosamines typically appear above $100 \mathrm{ppm}$. ${ }^{1} \mathrm{H}$ NMR $\delta_{\mathrm{H}}\left(500 \mathrm{MHz}, \mathrm{D}_{2} \mathrm{O}\right) 5.09(2 \mathrm{H}, \mathrm{s}, \mathrm{H}-1 \mathrm{~A}, \mathrm{H}-1 \mathrm{C}), 5.05(3 \mathrm{H}, \mathrm{t}$, $J=4.1, \mathrm{H}-1 \mathrm{~B}, \mathrm{H}-1 \mathrm{D}, \mathrm{H}-1 \mathrm{~F}), 5.00(1 \mathrm{H}, \mathrm{s}, \mathrm{H}-1 \mathrm{E}), 4.83(2 \mathrm{H}, \mathrm{s}), 4.43(1 \mathrm{H}$, s), 4.28-4.18 (10 H, m), $4.14(2 \mathrm{H}, \mathrm{d}, J 10.9), 4.00-3.90(8 \mathrm{H}, \mathrm{m}), 3.89$ (1 H, d, J 3.5), 3.88-3.80 (1 H, m), 3.71-3.58 (6 H, m), 3.50-3.46 $(1 \mathrm{H}, \mathrm{m}), 3.14-3.05(2 \mathrm{H}, \mathrm{m}), 1.98-1.95\left(11 \mathrm{H}, \mathrm{m}, 3 \mathrm{Ac}, \mathrm{CH}_{2}\right.$-linker $)$. $\delta_{\mathrm{C}}$ (values obtained from $\mathrm{F} 1$ dimension of HMQC spectrum) $\delta 101.2$ (C-1A, C-1C), 100.4 (C-1E), 95.6 (C-1B, C-1D, C-1F), 78.4, 75.8, 73.0, 71.8, 71.3, 68.5, 66.2, 62.7, 59.2, 55.3, 27.2, $26.9\left(\mathrm{CH}_{3}\right)$; HRMS $[\mathrm{M}]^{3-}$ $\mathrm{C}_{45} \mathrm{H}_{66} \mathrm{~N}_{4} \mathrm{Na}_{3} \mathrm{O}_{52} \mathrm{~S}_{6}{ }^{3-}$ calcd. 585.0226, obsd. 585.0218.

3-Aminopropyl 2-Deoxy-2-sulfoamino-6-O-sulfonate- $\alpha$-D-glucopyranosyl-(1 $\rightarrow 4)-2-O$-sulfonate- $\alpha$-L-idopyranosyluronate- $(1 \rightarrow 4)-2$ deoxy-2-sulfoamino-6-O-sulfonate- $\alpha$-D-glucopyranosyl- $(1 \rightarrow 4)-2-0$ sulfonate- $\alpha$-L-idopyranosyluronate- $(1 \rightarrow 4)$-2-deoxy-2-sulfoamino6-O-sulfonate- $\alpha$-D-glucopyranosyl- $(1 \rightarrow 4)$-2-O-sulfonate- $\alpha$ - $L$ idopyranosyluronate (22). Treatment of compound 19 (5 mg, $1.85 \mu \mathrm{mol}$ ) with the procedures for global debenzylation and methyl ester saponification provided $2.4 \mathrm{mg}$ of $\mathbf{2 2}$ in $63 \%$ yield from 19. NMR analysis showed that the anomeric carbons of $\mathbf{2 2}$ gave chemical shifts of 101.8 ( 1 carbon), 101.3 ( 2 carbons), 100.8 ( 1 carbon), 100.0 ( 1 carbon) and 99.5 (1 carbon) $\mathrm{ppm}$, respectively, which suggests that the glucosamines were $\mathrm{N}$-sulfated. These values were consistent with literature reports, ${ }^{67,68}$ where anomeric carbons of unsulfated glucosamines in heparin resonate around $94 \mathrm{ppm}$, while those of $\mathrm{N}$-sulfated glucosamines typically appear above $100 \mathrm{ppm} .{ }^{1} \mathrm{H}$ NMR $\delta_{\mathrm{H}}(500 \mathrm{MHz}$, $\left.\mathrm{D}_{2} \mathrm{O}\right) 5.38-5.26(2 \mathrm{H}, \mathrm{m}), 5.21(1 \mathrm{H}, \mathrm{d}, J 3.3), 5.13(1 \mathrm{H}, \mathrm{d}, J 3.7), 5.10$ $(1 \mathrm{H}, \mathrm{s}), 5.07-5.02(1 \mathrm{H}, \mathrm{m}), 4.83(1 \mathrm{H}, \mathrm{d}, J 3.1), 4.38(1 \mathrm{H}, \mathrm{d}, J 16.7)$, 4.29-4.16 (8 H, m), 4.14-4.11 (1 H, m), $4.08(1 \mathrm{H}, \mathrm{s}), 4.04(1 \mathrm{H}, \mathrm{s})$, 3.88-3.83 (1 H, m), 3.80-3.73 (7 H, m), 3.72-3.65 (2 H, m), 3.61 (3 H, t, J 9.4), 3.55-3.50 (2 H, m), 3.49-3.43 $(2 \mathrm{H}, \mathrm{m}), 3.16(2 \mathrm{H}, \mathrm{dd}$, $J 10.3,3.2), 3.12(1 \mathrm{H}, \mathrm{dd}, J 10.2,3.3), 3.09-3.05(1 \mathrm{H}, \mathrm{m}), 1.97-1.86(2$ $\mathrm{H}, \mathrm{m}) . \delta_{\mathrm{C}}$ (values obtained from $\mathrm{F} 1$ dimension of HMQC spectrum) $\delta$ 101.8, 101.3, 100.8, 100.0, 99.5, 78.2, 78.0, 76.0, 71.2, 71.1, 70.7, 69.2, 67.9, 59.6, 54.9, 54.7, 40.2, 27.8. HRMS $[\mathrm{M}]^{4-} \mathrm{C}_{39} \mathrm{H}_{55} \mathrm{~N}_{4} \mathrm{Na}_{7} \mathrm{O}_{58} \mathrm{~S}_{9}{ }^{4-}$ calcd. 488.9526, obsd. 488.9573 .

3-Aminopropyl 2-Deoxy-2-sulfoamino-6-O-sulfonate- $\alpha$-D-glucopyranosyl-(1 $\rightarrow 4)-2-0$-sulfonate- $\alpha$-L-idopyranosyluronate- $(1 \rightarrow 4)-2$ deoxy-2-sulfoamino-6-O-sulfonate- $\alpha$-D-glucopyranosyl-( $1 \rightarrow 4)-2-0$ sulfonate- $\alpha$-L-idopyranosyluronate (23). Compound 23 was prepared from 11 in 6 steps. First, $99 \mathrm{mg}(50 \mu \mathrm{mol})$ of 11 was treated with the general procedures for levulinoyl ester removal, 6-O oxidation, benzyl ester formation, and, lastly, TBS removal. This provided $65 \mathrm{mg}$ of product, $\mathrm{N}$-(benzyl)-benzyloxycarbonyl-3-aminopropyl 6-O-acetyl-2azido-3-O-benzyl-2-deoxy- $\alpha$-D-glucopyranosyl-( $1 \rightarrow 4)$-benzyl 2-O-benzoyl-3-O-benzyl- $\alpha$-L-idopyranosyluronate- $(1 \rightarrow 4)$-6-O-acetyl-2-azido-3$O$-benzyl-2-deoxy- $\alpha$-D-glucopyranosyl-( $1 \rightarrow 4)$-benzyl 2-O-benzoyl-3-Obenzyl- $\alpha$-L-idopyranosyluronate, in a $69 \%$ yield from $11 .{ }^{1} \mathrm{H}$ NMR $\left(500 \mathrm{MHz}, \mathrm{CDCl}_{3}\right) \delta 8.23-8.02(\mathrm{~m}, 5 \mathrm{H}), 7.58-7.10(\mathrm{~m}, 45 \mathrm{H}), 5.55(\mathrm{~d}$, $J=5.4 \mathrm{~Hz}, 1 \mathrm{H}, \mathrm{H}-1 \mathrm{~B}), 5.24(\mathrm{t}, J=5.3 \mathrm{~Hz}, 1 \mathrm{H}, \mathrm{H}-2 \mathrm{C}), 5.17-5.12(\mathrm{~m}$, $4 \mathrm{H}), 5.09-5.05(\mathrm{~m}, 3 \mathrm{H}, \mathrm{H}-1 \mathrm{~A}), 4.94(\mathrm{~d}, J=3.7 \mathrm{~Hz}, 1 \mathrm{H}, \mathrm{H}-2 \mathrm{D}), 4.81-$ $4.79(\mathrm{~m}, 2 \mathrm{H}), 4.72-4.68(\mathrm{~m}, 1 \mathrm{H}), 4.66(\mathrm{~d}, J=3.4 \mathrm{~Hz}, 1 \mathrm{H}, \mathrm{H}-5 \mathrm{C}), 4.64$ $(\mathrm{d}, J=4.9 \mathrm{~Hz}, 1 \mathrm{H}, \mathrm{H}-1 \mathrm{~B}), 4.50(\mathrm{t}, J=10.9 \mathrm{~Hz}, 2 \mathrm{H}), 4.47-4.38(\mathrm{~m}, 5 \mathrm{H})$, $4.37-4.33(\mathrm{~m}, 1 \mathrm{H}), 4.19-4.16(\mathrm{~m}, 1 \mathrm{H}, \mathrm{H}-3 \mathrm{C}), 4.15-4.11(\mathrm{~m}, 3 \mathrm{H}$, $\mathrm{H}-2 \mathrm{~A}), 4.09-4.07$ (m, 1H, H-4C), 3.99-3.93 (m, 2H), 3.88-3.83 (m, $2 \mathrm{H}), 3.80-3.71(\mathrm{~m}, 2 \mathrm{H}), 3.53-3.45(\mathrm{~m}, 3 \mathrm{H}), 3.45-3.37(\mathrm{~m}, 2 \mathrm{H})$, $3.35-3.26(\mathrm{~m}, 2 \mathrm{H}), 3.19(\mathrm{t}, J=3.4 \mathrm{~Hz}, 1 \mathrm{H}, \mathrm{H}-2 \mathrm{~B}), 3.17(\mathrm{t}, J=3.7 \mathrm{~Hz}$, $1 \mathrm{H}, \mathrm{H}-2 \mathrm{D}), 2.76(\mathrm{~d}, J=4.6 \mathrm{~Hz}, 1 \mathrm{H}, \mathrm{OH}), 2.13(\mathrm{~s}, 3 \mathrm{H}), 2.06(\mathrm{~s}, 3 \mathrm{H})$, $1.86-1.77(\mathrm{~m}, 2 \mathrm{H}) .{ }^{13} \mathrm{C} \mathrm{NMR}\left(125 \mathrm{MHz}, \mathrm{CDCl}_{3}\right) \delta 171.8,171.1,170.8$, $160.0,168.8,165.4,165.3,137.9,137.8,137.2$, 135.2, 134.9, 133.6, 130.1, $129.9,129.6,129.3,128.83,128.78,128.74,128.69,128.67,128.63$, $128.58,128.51,128.49,128.45,128.44,128.41,128.37,128.36,128.3$ $128.2,128.14,128.10,128.0,127.95,127.87,127.85,127.8,127.5$, $127.33,127.32,127.29,127.27,127.26,127.24,127.23,99.9,99.4,98.5$,
79.1, 78.5, 76.9, 76.89, 76.88, 76.87, 76.8, 76.1, 75.8, 75.0, 74.9, 74.5, $74.1,73.1,72.4,71.5,71.2,71.1,70.5,69.9,67.9,67.7,67.2,67.1,63.6$, $62.9,62.4,61.8,60.4,29.7,21.0,20.9,20.8,14.2$. HRMS $[\mathrm{M}+\mathrm{H}]^{+}$ $\mathrm{C}_{102} \mathrm{H}_{03} \mathrm{~N}_{7} \mathrm{O}_{27}{ }^{+}$calcd. 1858.6935 obsd. 1868.6931. By treating $9 \mathrm{mg}$ (4.8 $\mu \mathrm{mol}$ ) of $\mathrm{N}$-(benzyl)-benzyloxycarbonyl-3-aminopropyl 6-Oacetyl-2-azido-3-O-benzyl-2-deoxy- $\alpha$-D-glucopyranosyl-( $1 \rightarrow 4)$-benzyl 2-O-benzoyl-3-O-benzyl- $\alpha$-L-idopyranosyluronate- $(1 \rightarrow 4)-6-O$-acetyl2 -azido-3-O-benzyl-2-deoxy- $\alpha$-D-glucopyranosyl- $(1 \rightarrow 4)$-benzyl 2 - $O$ benzoyl-3-O-benzyl- $\alpha$-L-idopyranosyluronate with the general procedures for benzylation, 1,3-dithiopropane mediated azide reduction, $\mathrm{N}, \mathrm{O}$-sulfation, and finally global debenzylation and saponification produced $3 \mathrm{mg}$ of 23 in $49 \%$ yield (34\% from 11 ). ${ }^{1} \mathrm{H}$ NMR $\delta_{\mathrm{H}}$ $\left(500 \mathrm{MHz}, \mathrm{D}_{2} \mathrm{O}\right) 5.35(1 \mathrm{H}, \mathrm{d}, J 3.1), 5.28(1 \mathrm{H}, \mathrm{d}, J 3.2), 5.09(1 \mathrm{H}, \mathrm{s})$, 4.96-4.92 (1 H, m), 4.38 (1 H, d, J 3.0), 4.29-4.18 (3 H, m), 4.18-4.13 $(2 \mathrm{H}, \mathrm{m}), 4.09-4.05(3 \mathrm{H}, \mathrm{m}), 4.03-3.95(2 \mathrm{H}, \mathrm{m}), 3.95-3.81(3 \mathrm{H}, \mathrm{m})$, 3.73-3.56 (3 H, m), 3.55-3.50 (1 H, m), $3.45(1 \mathrm{H}, \mathrm{t}, J 9.4), 3.23(1 \mathrm{H}$, d, J 0.7), $3.16(1 \mathrm{H}, \mathrm{dd}, J 10.5,2.7), 3.12(1 \mathrm{H}, \mathrm{dd}, J 9.8,3.8), 3.09-3.00$ $(2 \mathrm{H}, \mathrm{m}), 1.92-1.84(2 \mathrm{H}, \mathrm{m}) . \delta_{\mathrm{C}}$ (values obtained from $\mathrm{F} 1$ dimension of HSQC spectrum) 101.0, 100.9, 98.6, 97.8, 79.3, 77.7, 77.6, 72.6, 71.60, 71.55, 71.3, 71.0, 70.9, 70.8, 68.3, 68.2, 68.1, 59.66, 59.61, 40.0, 27.8. HRMS $\mathrm{C}_{27} \mathrm{H}_{41} \mathrm{~N}_{3} \mathrm{O}_{39} \mathrm{Na}_{3} \mathrm{~S}_{6}{ }^{3-}$ calcd. 430.6450 obsd. 430.6460 .

3-Aminopropyl 2-Deoxy-2-sulfoamino- $\alpha$-D-glucopyranosyl-(1 $\rightarrow$ 4)- $\alpha$-L-idopyranosyluronate- $(1 \rightarrow 4)$-2-deoxy-2-sulfoamino- $\alpha$-Dglucopyranosyl-( $1 \rightarrow 4)$ - $\alpha$-L-idopyranosyluronate- $(1 \rightarrow 4)$-2-deoxy-2sulfoamino- $\alpha$-D-glucopyranosyl- $(1 \rightarrow 4)-2$-O-sulfonate- $\alpha-L-$ idopyranosyluronate (24). Compound 24 was prepared from compound 18 ( $43 \mathrm{mg}, 15.7 \mu \mathrm{mol})$. Treatment of 18 with the general procedure for saponification, followed by Staudinger reduction, provided $28 \mathrm{mg}$ of a hexasaccharide intermediate in a $95 \%$ yield over the two steps. HRMS $[\mathrm{M}-\mathrm{H}]^{-1} \mathrm{C}_{103} \mathrm{H}_{119} \mathrm{~N}_{4} \mathrm{O}_{33}{ }^{-1}$ calcd. 1940.7796 obsd. 1940.7793. The hexasaccharide intermediate $(4.3 \mathrm{mg}, 2.3 \mu \mathrm{mol})$ was then dissolved in $0.5 \mathrm{~mL}$ of $\mathrm{MeOH}$ and cooled to $0{ }^{\circ} \mathrm{C}$. The $\mathrm{pH}$ of the solution was brought to 9.5 by addition of $1 \mathrm{M}$ aqueous solution of $\mathrm{NaOH}$. Next, $6.3 \mathrm{mg}$ of sulfur trioxide triethylamine complex (5 equiv per amine) was added, and $\mathrm{pH}$ was maintained at 9.5 by addition of more $1 \mathrm{M} \mathrm{NaOH}$ as needed. The reaction was allowed to warm to room temperature and stirred overnight. By TLC (3:1:1 EtOAc: $\mathrm{MeOH}: \mathrm{H}_{2} \mathrm{O}$ $1 \% \mathrm{AcOH})$, the reaction was incomplete. An additional $2.5 \mathrm{mg}$ of sulfur trioxide triethylamine was added, and the reaction was stirred for an additional $12 \mathrm{~h}$. The reaction was diluted with 1:1 DCM:MeOH and eluted from a Sephadex LH-20 column with the same mixture. The product of selective $\mathrm{N}$-sulfation was fully deprotected by global debenzylation, providing $2 \mathrm{mg}$ of $\mathbf{2 4}$ in $70 \%$ yield over the two steps. ${ }^{1} \mathrm{H}$ NMR $\delta_{\mathrm{H}}\left(900 \mathrm{MHz}, \mathrm{D}_{2} \mathrm{O}\right) 5.26(1 \mathrm{H}, \mathrm{d}, J 3.5, \mathrm{H}-1 \mathrm{~F}), 5.25(1 \mathrm{H}, \mathrm{d}$, J 3.5, H-1D), 5.20 (1 H, d, J 3.6, H-1B), 4.87 (4 H, d, J 7.9, H-1C, H-1E, H-5C, H-5E), $4.80(1 \mathrm{H}, \mathrm{s}, \mathrm{H}-1 \mathrm{~A}), 4.44(1 \mathrm{H}, \mathrm{s}, \mathrm{H}-5 \mathrm{~A}), 4.07(1 \mathrm{H}, \mathrm{t}, J 2.9$, H-3A), 4.05-4.01 (2 H, m, H-3C, H-3E), 3.98-3.94 (2 H, m, H-4C, H$4 \mathrm{E}), 3.93(1 \mathrm{H}, \mathrm{s}, \mathrm{H}-4 \mathrm{~A}), 3.78$ ( $1 \mathrm{H}, \mathrm{ddd}, J 10.0,7.9,4.7, \mathrm{H}$-linker $), 3.72-$ 3.55 (16 H, m, H-2A, H-4B, H-5B, H-6B, H-2C, H-4D, H-5D, H-6D, H-2E, H-5F, H-6F, H-linker), 3.55-3.52 (1 H, m, H-3D), $3.49(1 \mathrm{H}, \mathrm{t}$, J9.8, H-3F), $3.38(1 \mathrm{H}, \mathrm{t}, J 9.6, \mathrm{H}-4 \mathrm{~F}), 3.14-3.10(2 \mathrm{H}, \mathrm{m}, \mathrm{H}-2 \mathrm{~B}, \mathrm{H}-2 \mathrm{D})$, 3.09 ( $1 \mathrm{H}, \mathrm{dd}, J 10.4,3.5, \mathrm{H}-2 \mathrm{~F}), 3.06-3.02\left(2 \mathrm{H}, \mathrm{m}, \mathrm{CH}_{2}\right.$-linker $), 1.92-$ $1.84\left(2 \mathrm{H}, \mathrm{m}, \mathrm{CH}_{2}\right.$-linker). ${ }^{13} \mathrm{C}$ NMR $\left(225 \mathrm{MHz}, \mathrm{D}_{2} \mathrm{O}\right) \delta 176.3,175.7$, 103.0 (C-1C), 102.9 (C-1E), 101.9 (C-1A), 97.4 (C-1D, C-1F), 97.3 (C-1B), 78.5, 78.4, 76.2, 76.0, 75.9, 73.4, 72.7, 72.66, 72.5, 71.2, 71.1, 71.0, 70.3, 70.2, 69.9, 69.5, 69.3, 69.0, 68.4, 68.0, 61.6, 61.2, 61.1, 59.5, 59.46, 59.3, 57.0, 39.8, 27.7. HRMS $[\mathrm{M}]^{3-} \mathrm{C}_{39} \mathrm{H}_{63} \mathrm{~N}_{4} \mathrm{O}_{40} \mathrm{~S}_{3}{ }^{3-}$ calcd. 441.0732 , obsd. 441.0717.

3-Aminopropyl 2-Deoxy-2-sulfoamino-6-O-sulfonate- $\alpha$-D-glucopyranosyl- $(1 \rightarrow 4)$ - $\alpha$-L-idopyranosyluronate- $(1 \rightarrow 4)$-2-deoxy-2-sulfoamino-6-O-sulfonate- $\alpha$-D-glucopyranosyl- $(1 \rightarrow 4)$ - $\alpha$-L-idopyranosyluronate- $(1 \rightarrow 4)$-2-deoxy-2-sulfoamino-6-O-sulfonate- $\alpha$ - $D$-glucopyranosyl- $(1 \rightarrow 4)-\alpha$-L-idopyranosyluronate $(25)$. Compound 25 was prepared from $0.5 \mathrm{mg}$ of $\mathbf{2 4}$ using the general procedure for enzymatic sulfation and 6-OST-1 and 6-OST-3 as the enzymes. This produced 25 in $67 \%$ yield after purification. ${ }^{1} \mathrm{H}$ NMR $\delta_{\mathrm{H}}\left(900 \mathrm{MHz}, \mathrm{D}_{2} \mathrm{O}\right) 5.23(1 \mathrm{H}$, d, J 3.6, H-1B ), 5.22 (1 H, d, J3.7, H-1D), 5.20 (1 H, d, J3.5, H-1F $), 4.98$ (1 H, s, H-1C), 4.95 ( $1 \mathrm{H}, \mathrm{s}, \mathrm{H}-1 \mathrm{E}), 4.83-4.75(2 \mathrm{H}, \mathrm{m}, \mathrm{H}-1 \mathrm{~A}), 4.36$ (1 $\mathrm{H}, \mathrm{s}, \mathrm{H}-5 \mathrm{~A}), 4.26-4.20$ (3 H, m, H-6B, H-6D, H-6F), 4.11-4.07 (2 H, m, H-6B, H-6D), 4.07-4.03 (2 H, m, H-3A, H-6F), 4.03-4.01 (1 H, m), 3.97-3.91 (3 H, m, H-5B, H-5D, H-5F), 3.91-3.88 (1 H, m, H-4A), 
3.83-3.80 (1 H, m, H-4B), 3.80-3.75 (2 H, m), 3.74-3.69 (3 H, m, H-2C, H-2E), 3.65-3.62 (2 H, m), 3.62-3.54 (5 H, m, H-2A), 3.54$3.51(1 \mathrm{H}, \mathrm{m}, \mathrm{H}-3 \mathrm{~B}), 3.47-3.44(1 \mathrm{H}, \mathrm{m}, \mathrm{H}-2 \mathrm{~B}), 3.15-3.09(3 \mathrm{H}, \mathrm{m}$, H-2B, H-2D, H-2F), 3.05-3.00 (2 H, m, $\mathrm{CH}_{2}$-linker), 1.90-1.85 (2 H, m, $\mathrm{CH}_{2}$-linker). $\delta_{\mathrm{C}}$ (values obtained from $\mathrm{F} 1$ dimension of $\mathrm{HSQC}$ spectrum) 103.1 (C-1C, C-1E), 101.7 (C-1A), 96.7 (C-1B, C-1D, C-1F), 78.7, 75.7, 75.6, 72.2, 71.1, 70.1, 70.0, 69.6, 69.3, 69.2, 68.9, 68.3, 67.8, 58.8, 27.8. HRMS $[\mathrm{M}]^{3-} \mathrm{C}_{39} \mathrm{H}_{60} \mathrm{~N}_{4} \mathrm{Na}_{3} \mathrm{O}_{49} \mathrm{~S}_{6}{ }^{3-}$ calcd. 543.0120, obsd. 543.0130 .

3-Aminopropyl 2-Deoxy-2-sulfoamino- $\alpha$-D-glucopyranosyl-(1 $\rightarrow$ 4)-2-O-sulfonate- $\alpha$-L-idopyranosyluronate-(1 $\rightarrow 4)$-2-deoxy-2-sulfoamino- $\alpha$-D-glucopyranosyl-(1 $\rightarrow 4)-2-0$-sulfonate- $\alpha$-L-idopyranosyluronate-( $1 \rightarrow 4)$-2-deoxy-2-sulfoamino- $\alpha$-D-glucopyranosyl- $(1 \rightarrow$ 4)-2-O-sulfonate- $\alpha$-L-idopyranosyluronate (26). Compound 26 was prepared from $500 \mu \mathrm{g}$ of compound 24 following the general procedure for enzymatic sulfation using 2-OST as the enzyme. This provided 26 in $82 \%$ yield after purification. ${ }^{1} \mathrm{H}$ NMR $\delta_{\mathrm{H}}\left(900 \mathrm{MHz}, \mathrm{D}_{2} \mathrm{O}\right) 5.22(1 \mathrm{H}, \mathrm{d}$, J 3.6, H-1F), 5.19 (2 H, d, J 3.4, H-1B, H-1D), 5.16 (2 H, m, H-1C, H-1E), 5.15 (1 H, s), 4.78 (1 H, s, H-1A), 4.77-4.74 (4 H, m, H-5B, H-5D, H-6B, H-6D), 4.36-4.34 (1 H, m, H-5A), 4.22 (2 H, s, H-2C, H-2E), 4.13 (2 H, dd, J 7.7, 4.2, H-3C, H-3E), 4.06-4.04 (1 H, m, H-3A), 3.93 (3 H, d, J 10.2, H-4A, H-4C, H-4E), 3.81-3.65 (10 H, m, H-5B, H-5D), 3.62-3.57 (4 H, m, H-2A, H-3F), 3.54 (2H, t, J 9.8, H-3B, H-3D) 3.35 $(2 \mathrm{H}, \mathrm{t}, J$ 9.8, H-4B, H-4D), $3.13(1 \mathrm{H}, \mathrm{dd}, J 10.3,3.1, \mathrm{H}-2 \mathrm{~F}), 3.12-3.08$ $(2 \mathrm{H}, \mathrm{m}, \mathrm{H}-2 \mathrm{~B}, \mathrm{H}-2 \mathrm{D}), 3.04-3.00\left(2 \mathrm{H}, \mathrm{m}\right.$, linker $\left.\mathrm{CH}_{2}\right), 1.91-1.86$ $\left(2 \mathrm{H}, \mathrm{m}\right.$, linker $\left.\mathrm{CH}_{2}\right) . \delta_{\mathrm{C}}$ (values obtained from $\mathrm{F} 1$ dimension of $\mathrm{HMQC}$ spectrum) 102.5 (C-1A), 101.0 (C-1C, C-1E), 99.5 (C-1B, C-D), 97.7 (C-1F), 79.2, 77.6, 76.7, 73.4, 73.1, 72.2. 70.5, 69.8, 69.1, 61.4, 60.0, 39.8, 27.8. HRMS $[\mathrm{M}]^{3-} \mathrm{C}_{39} \mathrm{H}_{59} \mathrm{~N}_{4} \mathrm{Na}_{4} \mathrm{O}_{46} \mathrm{~S}_{5}{ }^{3-}$ calcd. 523.6870, obsd. 523.6890.

3-Aminopropyl 2-Deoxy-2-sulfoamino-6-O-sulfonate- $\alpha$-D-glucopyranosyl- $(1 \rightarrow 4)-2$-O-sulfonate- $\alpha$ - - -idopyranosyluronate- $(1 \rightarrow 4)-2$ deoxy-2-sulfoamino-6-O-sulfonate- $\alpha$-D-glucopyranosyl- $(1 \rightarrow 4)-2-O-$ sulfonate- $\alpha$-L-idopyranosyluronate- $(1 \rightarrow 4)$-2-deoxy-2-sulfoamino$\alpha$-D-glucopyranosyl-( $1 \rightarrow 4)$-2-O-sulfonate- $\alpha$-L-idopyranosyluronate (27). Compound 27 was prepared from $0.5 \mathrm{mg}$ of compound 26 using the procedure for enzymatic sulfation. Utilizing enzymes 6-OST-1 and 6-OST-3 provided a $39 \%$ yield of 27 after purification. $\delta_{\mathrm{H}}(900 \mathrm{MHz}$, $\left.\mathrm{D}_{2} \mathrm{O}\right) 5.30(1 \mathrm{H}, \mathrm{d}, J 3.1, \mathrm{H}-1 \mathrm{~F}), 5.22(1 \mathrm{H}, \mathrm{d}, J 3.8, \mathrm{H}-1 \mathrm{D}), 5.20(1 \mathrm{H}, \mathrm{d}, J$ 3.3, H-1B), 5.18 (1 H, s, H-1C), $5.14(1 \mathrm{H}, \mathrm{s}, \mathrm{H}-1 \mathrm{E}), 4.78(1 \mathrm{H}, \mathrm{d}, J$ 2.2, H-1A), 4.77 (1H, s, H-5C) 4.74 (1 H, s, H-5E), 4.35 (1 H, d, J 2.1, H-5A), 4.30 ( $2 \mathrm{H}, \mathrm{d}, J 11.3, \mathrm{H}-6 \mathrm{D}, \mathrm{H}-6 \mathrm{~F}), 4.26-4.21$ ( $2 \mathrm{H}, \mathrm{m}, \mathrm{H}-2 \mathrm{C}, \mathrm{H}-2 \mathrm{E})$, $4.15(2 \mathrm{H}, \mathrm{d}, J$ 10.6, H-6D, H-6F), 4.13-4.08 (2 H, m, H-3C, H-3E), 4.06-4.04 (1 H, m, H-3A), 3.99 (1 H, d, J 2.3, H-4E), 3.96-3.94 (1 H, m, H-4C), 3.93-3.92 (1 H, m, H-4A), 3.91-3.87 (2 H, m, H-5D, H-5F), 3.82-3.76 ( $2 \mathrm{H}, \mathrm{m}, \mathrm{H}-5 \mathrm{~B}$, linker), 3.73-3.71 (2 H, m, H-4B, H-6B), 3.70-3.66 (1 H, m, H-4D), 3.63-3.56 (5 H, m, H-2A, H-3B, H-3D, H-6B, H-linker), 3.53 ( $1 \mathrm{H}, \mathrm{t}, J$ 9.9, H-3F), $3.46(1 \mathrm{H}, \mathrm{t}, J 9.6, \mathrm{H}-4 \mathrm{~F}), 3.17$ (1 H, dd, J 10.3, 3.0, H-2D), 3.13 (1 H, dd, J 10.4, 3.3, H-2F), $3.10(1 \mathrm{H}$, dd, J 9.5, 3.3, H-1B), 3.05-3.00 ( $2 \mathrm{H}, \mathrm{m}, \mathrm{CH}_{2}$-linker $), 1.91-1.86(2 \mathrm{H}$, $\mathrm{m}, \mathrm{CH}_{2}$-linker). $\delta_{\mathrm{C}}$ (values obtained from $\mathrm{F} 1$ dimension of HMQC spectrum) 102.2 (C-1A), 100.9 (C-1C, C-1E), 99.2 (C-1B, C-1D), 97.5 (C-F), 77.8, 77.5, 77.4, 76.5, 72.8, 71.5, 71.4, 71.2, 71.1, 70.8, 70.5, 70.3, $70.1,69.8,69.1,68.1,61.7,59.6,40.2,27.8$. HRMS $[\mathrm{M}]^{3-}$ $\mathrm{C}_{39} \mathrm{H}_{59} \mathrm{~N}_{4} \mathrm{Na}_{4} \mathrm{O}_{52} \mathrm{~S}_{7}{ }^{3-}$ calcd. 576.9916, obsd. 576.9904.

3-Aminopropyl 2-Deoxy-2-sulfoamino-6-O-sulfonate- $\alpha$-D-glucopyranosyl-(1 $\rightarrow 4$ )-2-O-sulfonate- $\alpha$-L-idopyranosyluronate (28). Compound 28 was prepared from $3.3(47 \mathrm{mg}, 46 \mu \mathrm{mol})$ was treated with the conditions for benzylation, followed by the general procedure to remove levulinoyl esters. The product was then oxidized and protected as a benzyl ester according to the procedures for oxidation and benzyl ester formation. Treatment of the oxidized product sequentially with the general procedures for saponification, Staudinger reduction, $\mathrm{O}$-sulfation, $\mathrm{N}$-sulfation, and finally global debenzylation provided $9 \mathrm{mg}$ of 28 in $34 \%$ yield from $3 .{ }^{1} \mathrm{H}$ NMR $\delta_{\mathrm{H}}\left(600 \mathrm{MHz}, \mathrm{D}_{2} \mathrm{O}\right)$ 5.29 (1 H, d, J 3.6, H-1B), 4.99 (1 H, d, J 3.1, H-1A), 4.37 (1 H, d, J 2.8, H-5A), 4.24-4.20 (1 H, m, H-6B), 4.16-4.11 (1 H, m, H-2A), 4.11$4.05(2 \mathrm{H}, \mathrm{m}, \mathrm{H}-6 \mathrm{~B}, \mathrm{H}-3 \mathrm{~A}), 4.00-3.95(1 \mathrm{H}, \mathrm{m}, \mathrm{H}-4 \mathrm{~A}), 3.88-3.76(2 \mathrm{H}$, $\mathrm{m}$, linker-H, H-5B), 3.62-3.55 ( $1 \mathrm{H}, \mathrm{m}$, linker-H), $3.52(1 \mathrm{H}, \mathrm{dd}, J 10.1$, 9.3, H-3B), 3.44 (1 H, dd, J 10.1, 9.3, H-4B), 3.13 (1 H, dd, J 10.3, 3.5, $\mathrm{H}-2 \mathrm{~B}), 3.06-3.02\left(2 \mathrm{H}, \mathrm{m}\right.$, linker- $\left.\mathrm{CH}_{2}\right), 1.91-1.85\left(2 \mathrm{H}, \mathrm{m}\right.$, linker- $\left.\mathrm{CH}_{2}\right)$;
$\delta_{\mathrm{C}}$ (values obtained from F1 dimension of HMQC spectrum) 100.5 (C-1A), 98.4 (C-1B), 78.1 (C-2A), 77.6 (C-4A), 72.7 (C-3B), 71.8 (C-5B), 70.9 (C-4B), 70.6 (C-5A), 70.5 (C-3A), 68.3 (C-linker), 68.2 (C-6B), 59.7 (C-2B), 40.2 (C-linker), 27.8 (C-linker). HRMS [M] $]^{+}$ $\mathrm{C}_{15} \mathrm{H}_{25} \mathrm{~N}_{2} \mathrm{O}_{20} \mathrm{Na}_{4} \mathrm{~S}_{3}{ }^{+}$calcd. 740.9748 obsd. 740.9734 .

\section{ASSOCIATED CONTENT}

\section{Supporting Information}

The Supporting Information is available free of charge on the ACS Publications website at DOI: 10.1021/acs.joc.5b02172.

Additional glycan microarray images and selected NMR spectra (PDF)

\section{AUTHOR INFORMATION}

\section{Corresponding Authors}

*E-mail: liuj@email.unc.edu. Tel: 919-843-6511. Fax: 919-8436511 (J.L.).

*E-mail: xuefei@chemistry.msu.edu. Tel: 517-355-9715, ext. 329. Fax: 517-353-1793 (X.H.).

\section{Notes}

The authors declare no competing financial interest.

\section{ACKNOWLEDGMENTS}

This work was supported by the National Science Foundation (CHE 1507226) and the National Institute of General Medical Sciences, NIH (R01GM072667, U01GM116262, and U01GM102137). We are grateful for the helpful suggestions from Dr. David Bonnaffé.

\section{REFERENCES}

(1) Bishop, J. R.; Schuksz, M.; Esko, J. D. Nature 2007, 446, 1030.

(2) Parish, C. R. Nat. Rev. Immunol. 2006, 6, 633.

(3) Sasisekharan, R.; Shriver, Z.; Venkataraman, G.; Narayanasami, U. Nat. Rev. Cancer 2002, 2, 521.

(4) Capila, I.; Linhardt, R. J. Angew. Chem., Int. Ed. 2002, 41, 390.

(5) Dulaney, S. B.; Huang, X. Adv. Carbohydr. Chem. Biochem. 2012, 67, 95.

(6) Linhardt, R. J.; Dordick, J. S.; Deangelis, P. L.; Liu, J. Semin. Thromb. Hemostasis 2007, 33, 453.

(7) Doneanu, C. E.; Chen, W.; Gebler, J. C. Anal. Chem. 2009, 81, 3485.

(8) Noti, C.; Seeberger, P. H. In Chemistry and Biology of Heparin and Heparan Sulfate; Garg, H. G., Linhardt, R. J., Hales, C. A., Eds.; Elsevier: Oxford, U.K., 2005; p 79.

(9) Petitou, M.; van Boeckel, C. A. A. Angew. Chem., Int. Ed. 2004, 43, 3118.

(10) Codée, J. D. C.; Overkleeft, H. S.; van der Marel, G. A.; van Boeckel, C. A. A. Drug Discovery Today: Technol. 2004, 1, 317.

(11) Poletti, L.; Lay, L. Eur. J. Org. Chem. 2003, 2003, 2999.

(12) Hansen, S. U.; Miller, G. J.; Cliff, M. J.; Jayson, G. C.; Gardiner, J. M. Chem. Sci. 2015, 6, 6158.

(13) Hansen, S. U.; Miller, G. J.; Cole, C.; Rushton, G.; Avizienyte, E.; Jayson, G. C.; Gardiner, J. M. Nat. Commun. 2013, 4, 2016.

(14) Miller, G. J.; Hansen, S. U.; Avizienyte, E.; Rushton, G.; Cole, C.; Jayson, G. C.; Gardiner, J. M. Chem. Sci. 2013, 4, 3218.

(15) Hansen, S. U.; Miller, J. D.; Jayson, G. C.; Gardiner, J. M. Org. Lett. 2013, 15, 88.

(16) Zulueta, M. M. L.; Lin, S.-Y.; Lin, Y.-T.; Huang, C.-J.; Wang, C.-C.; Ku, C.-C.; Shi, Z.; Chyan, C.-L.; Irene, D.; Lim, L.-H.; Tsai, T.-I.; Hu, Y.-P.; Arco, S. D.; Wong, C.-H.; Hung, S.-C. J. Am. Chem. Soc. 2012, 134, 8988-8995 and references cited therein.

(17) Wang, Z.; Xu, Y.; Yang, B.; Tiruchinapally, G.; Sun, B.; Liu, R.; Dulaney, S.; Liu, J.; Huang, X. Chem.-Eur. J. 2010, 16, 8365.

(18) Polat, T.; Wong, C.-H. J. Am. Chem. Soc. 2007, 129, 12795. 
(19) Noti, C.; de Paz, J. L.; Polito, L.; Seeberger, P. H. Chem.-Eur. J. 2006, 12, 8664.

(20) de Paz, J. L.; Martín-Lomas, M. Eur. J. Org. Chem. 2005, 2005, 1849.

(21) Sheng, G. J.; Oh, Y. I.; Chang, S.-K.; Hsieh-Wilson, L. C. J. Am. Chem. Soc. 2013, 135, 10898.

(22) Xu, Y.; Wang, Z.; Liu, R.; Bridges, A. S.; Huang, X.; Liu, J. Glycobiology 2012, 22, 96.

(23) Xu, Y.; Masuko, S.; Takieddin, M.; Xu, H.; Liu, R.; Jing, J.; Mousa, S. A.; Linhardt, R. J.; Liu, J. Science 2011, 334, 498.

(24) Hu, Y.-P.; Lin, S.-Y.; Huang, C.-Y.; Zulueta, M. M. L.; Liu, J.-Y.; Chang, W.; Hung, S.-C. Nat. Chem. 2011, 3, 557.

(25) Tiruchinapally, G.; Yin, Z.; El-Dakdouki, M.; Wang, Z.; Huang, X. Chem.-Eur. J. 2011, 17, 10106.

(26) Czechura, P.; Guedes, N.; Kopitzki, S.; Vazquez, N.; MartinLomas, M.; Reichardt, N.-C. Chem. Commun. 2011, 47, 2390.

(27) Chen, Y.; Li, Y.; Yu, H.; Sugiarto, G.; Thon, V.; Hwang, J.; Ding, L.; Hie, L.; Chen, X. Angew. Chem., Int. Ed. 2013, 52, 11852.

(28) Arungundram, S.; Al-Mafraji, K.; Asong, J.; Leach, F. E.; Amster, I. J.; Venot, A.; Turnbull, J. E.; Boons, G. J. J. Am. Chem. Soc. 2009, 131, 17394.

(29) Baleux, F.; Loureiro-Morais, L.; Hersant, Y.; Clayette, P.; Arenzana-Seisdedos, F.; Bonnaffé, D.; Lortat-Jacob, H. Nat. Chem. Biol. 2009, 5, 743.

(30) Chen, J.; Zhou, Y.; Chen, C.; Xu, W.; Yu, B. Carbohydr. Res. 2008, 343, 2853.

(31) Dilhas, A.; Lucas, R.; Loureiro-Morais, L.; Hersant, Y.; Bonnaffe, D. J. Comb. Chem. 2008, 10, 166.

(32) Tatai, J.; Fügedi, P. Tetrahedron 2008, 64, 9865.

(33) Codée, J. D. C.; Stubba, B.; Schiattarella, M.; Overkleeft, H. S.; van Boeckel, C. A. A.; van Boom, J. H.; van der Marel, G. A. J. Am. Chem. Soc. 2005, 127, 3767.

(34) Fan, R.-H.; Achkar, J.; Hernandez-Torres, J. M.; Wei, A. Org. Lett. 2005, 7, 5095.

(35) Ojeda, R.; Terenti, O.; de Paz, J.-L.; Martin-Lomas, M. Glycoconjugate J. 2004, 21, 179.

(36) Lubineau, A.; Lortat-Jacob, H.; Gavard, O.; Sarrazin, S.; Bonnaffé, D. Chem.-Eur. J. 2004, 10, 4265.

(37) Poletti, L.; Fleischer, M.; Vogel, C.; Guerrini, M.; Torri, G.; Lay, L. Eur. J. Org. Chem. 2001, 2001, 2727.

(38) Petitou, M.; Herault, J.-P.; Bernat, A.; Driguez, P.-A.; Duchaussoy, P.; Lormeau, J.-C.; Herbert, J.-M. Nature 1999, 398, 417.

(39) Sinaÿ, P.; Jacquinet, J. C.; Petitou, M.; Duchaussoy, P.; Lederman, I.; Choay, J.; Torri, G. Carbohydr. Res. 1984, 132, C5.

(40) Lucas, R.; Hamza, D.; Lubineau, A.; Bonnaffé, D. Eur. J. Org. Chem. 2004, 2004, 2107.

(41) Lohman, G. J. S.; Seeberger, P. H. J. Org. Chem. 2004, 69, 4081.

(42) Hu, Y.-P.; Zhong, Y.-Q.; Chen, Z.-G.; Chen, C.-Y.; Shi, Z.; Zulueta, M. M. L.; Ku, C.-C.; Lee, P.-Y.; Wang, C.-C.; Hung, S.-C. J. Am. Chem. Soc. 2012, 134, 20722.

(43) Lu, L.-D.; Shie, C.-R.; Kulkarni, S. S.; Pan, G.-R.; Lu, X.-A.; Hung,

S. C. Org. Lett. 2006, 8, 5995.

(44) Xu, Y.; Cai, C.; Chandarajoti, K.; Li, L.; Hsieh, P.; Pham, T.; Sparkenbaugh, E. M.; Sheng, J.; Key, N.; Pawlinski, R.; Harris, E.; Linhardt, R. J.; Liu, J. Nat. Chem. Biol. 2014, 10, 248.

(45) Kuberan, B.; Lech, M. Z.; Beeler, D. L.; Wu, Z. L.; Rosenberg, R. D. Nat. Biotechnol. 2003, 21, 1343.

(46) Huang, X.; Huang, L.; Wang, H.; Ye, X.-S. Angew. Chem., Int. Ed. 2004, 43, 5221.

(47) Crich, D.; Smith, M.; Yao, Q.; Picione, J. Synthesis 2001, 2001, 0323.

(48) Bock, K.; Pedersen, C. J. Chem. Soc., Perkin Trans. 2 1974, 293.

(49) Huang, L.; Huang, X. Chem.-Eur. J. 2007, 13, 529.

(50) van den Bos, L. J.; Codee, J. D. C.; van der Toorn, J. C.; Boltje, T. J.; van Boom, J. H.; Overkleeft, H. S.; van der Marel, G. A. Org. Lett. 2004, 6, 2165.

(51) Huang, L.; Teumelsan, N.; Huang, X. Chem.-Eur. J. 2006, 12, 5246.
(52) Iversen, T.; Bundle, D. R. J. Chem. Soc., Chem. Commun. 1981, 1240.

(53) Wei, A.; Haudrechy, A.; Audin, C.; Jun, H.-S.; Haudrechy-Bretel, N.; Kishi, Y. J. Org. Chem. 1995, 60, 2160.

(54) Liu, R.; Xu, Y.; Chen, M.; Weiwer, M.; Zhou, X.; Bridges, A. S.; Deangelis, P. L.; Zhang, Q.; Linhardt, R. J.; Liu, J. J. Biol. Chem. 2010, 285,34240 .

(55) Jacobsson, I.; Lindahl, B. J. Biol. Chem. 1980, 255, 5094.

(56) Gallagher, J. T.; Turnbull, J. E. Glycobiology 1992, 2, 523.

(57) Basilico, C.; Moscatelli, D. Adv. Cancer Res. 1992, 59, 115.

(58) Schlessinger, J.; Plotnikov, A. N.; Ibrahimi, O. A.; Eliseenkova, A. V.; Yeh, B. K.; Yayon, A.; Linhardt, R. J.; Mohammadi, M. Mol. Cell 2000, 6, 743.

(59) Park, S.; Gildersleeve, J. C.; Blixt, O.; Shin, I. Chem. Soc. Rev. 2013, $42,4310$.

(60) Rogers, C. J.; Clark, P. m.; Tully, S. E.; Abrol, R.; Garcia, K. C.; Goddard, W. A., III; Hsieh-Wilson, L. C. Proc. Natl. Acad. Sci. U. S. A. 2011, 108, 9747.

(61) Huang, M. L.; Smith, R. A. A.; Trieger, G. W.; Godula, K. J. Am. Chem. Soc. 2014, 136, 10565-10568.

(62) Shipp, E. L.; Hsieh-Wilson, L. C. Chem. Biol. 2007, 14, 195.

(63) Dheur, J.; Dendane, N.; Desmet, R.; Dahmani, F.; Goormachtigh, G.; Vicogne, J.; Fafeur, V.; Melnyk, O. Methods Mol. Biol. 2012, 808, 231.

(64) Yin, J.; Seeberger, P. H. Methods Enzymol. 2010, 478, 197.

(65) Raman, R.; Sasisekharan, V.; Sasisekharan, R. Chem. Biol. 2005, 12, 267.

(66) Creary, X. Org. Synth. 1986, 64, 207.

(67) Yates, E. A.; Santini, F.; Guerrini, M.; Naggi, A.; Torri, G.; Casu, B. Carbohydr. Res. 1996, 294, 15.

(68) Yates, E. A.; Santini, F.; De Cristofano, B.; Payre, N.; Cosentino, C.; Guerrini, M.; Naggi, A.; Torri, G.; Hricovini, M. Carbohydr. Res. 2000, 329, 239. 